\title{
PATRÍCIA FERREIRA DE CASTRO
}

Afecções cirúrgicas em aves: estudo retrospectivo

Dissertação apresentada ao Programa de Pós-Graduação em Clínica Cirúrgica Veterinária da Faculdade de Medicina Veterinária e Zootecnia da Universidade de São Paulo para obtenção do título de Mestre em Ciências

Departamento:

Cirurgia

Área de concentração:

Clínica Cirúrgica Veterinária

Orientadora:

Profa. Dra. Julia Maria Matera

\section{São Paulo}


Autorizo a reprodução parcial ou total desta obra, para fins acadêmicos, desde que citada a fonte.

DADOS INTERNACIONAIS DE CATALOGAÇÃO-NA-PUBLICAÇÃO

(Biblioteca Virginie Buff D’Ápice da Faculdade de Medicina Veterinária e Zootecnia da Universidade de São Paulo)

Castro, Patrícia Ferreira de

Afecções cirúrgicas em aves: estudo retrospectivo / Patrícia Ferreira de Castro. -- 2010.

170 f. : il.

Dissertação (Mestrado) - Universidade de São Paulo. Faculdade de Medicina Veterinária e Zootecnia. Departamento de Cirurgia, São Paulo, 2010.

Programa de Pós-Graduação: Clínica Cirurgia Veterinária.

Área de concentração: Clínica Cirurgia Veterinária.

Orientador: Profa. Dra. Julia Maria Matera.

1. Cirurgia veterinária. 2. Ortopedia. 3. Tecidos moles. 4. Animais silvestres. 5. Psittaciformes. I. Título. 


\section{CERTIFICADO}

Certificamos que o Projeto intitulado "Análise retrospectiva das afecções cirúrgicas em aves", protocolado sob o n¹494/2008, sob a responsabilidade da Profa. Dra. Júlia Maria Matera, está de acordo com os princípios éticos de experimentação animal da Comissão de Bioética da Faculdade de Medicina Veterinária e Zootecnia da Universidade de São Paulo e foi aprovado em reunião de 01 de outubro de 2008.

We certify that the Research "Avian Surgical affection: retrospective analysis", protocol number 1494/2008, under the responsibility Profa. Dra. Júlia Maria Matera, agree with Ethical Principles in Animal Research adopted by Bioethic Commission of the School of Veterinary Medicine and Animal Science of University of São Paulo and was approved in the meeting of day 10/01/08.

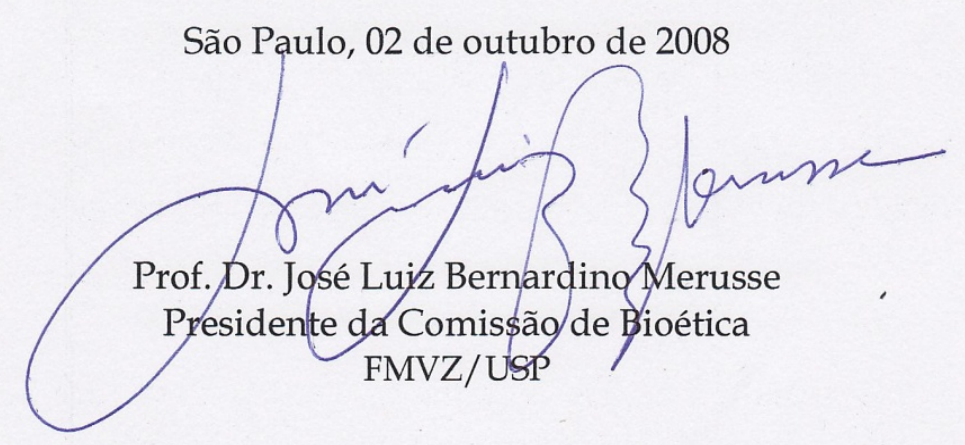




\section{FOLHA DE AVALIAÇÃO}

Nome: CASTRO, Patrícia Ferreira de

Título: Afecções cirúrgicas em aves: estudo retrospectivo

Dissertação apresentada ao Programa de Pós-Graduação em Clínica Cirúrgica Veterinária da Faculdade de Medicina Veterinária e Zootecnia da Universidade de São Paulo para obtenção do título de Mestre em Ciências

Data:

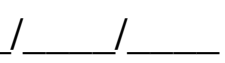

Banca Examinadora

Prof. Dr. Instituição:

Assinatura: Julgamento:

Prof. Dr. Instituição:

Assinatura: Julgamento:

Prof. Dr. Instituição:

Assinatura: Julgamento: 

Aos meus pais Geraldo e Belinha, A mio marito Patrizio. 



\section{AGRADECIMENTOS}

A Deus pela vida, por iluminar meu caminho e por mais esta conquista.

Aos meus pais, por tudo. Vocês são meu exemplo de verdadeiro amor e dedicação.

À Professora, "chefa", orientadora e amiga Julia Maria Matera, pela contribuição na minha formação acadêmica, profissional e pessoal, exemplo de amor e dedicação aos animais. A sua confiança e torcida fazem toda a diferença.

À Professora Denise Tabacchi Fantoni pelo incentivo, amizade e disposição para a realização das anestesias e à médica veterinária Marta Brito Guimarães pela amizade e confiança. Verdadeiro trabalho em equipe.

À Professora Silvia Renata Gaido Cortopassi pela amizade e participação em momentos especiais.

Às médicas veterinárias do Serviço de Cirurgia de Pequenos Animais do HOVETFMVZ/USP e amigas, Andressa Gianotti Campos Nitrini, Sandra Aparecida Rosner, Tatiana Soares da Silva e Viviane Sanchez Galeazzi, pelo constante aprendizado, carinho e colaboração.

Aos enfermeiros do Serviço de Cirurgia de Pequenos Animais do HOVETFMVZ/USP Cledson Lelis dos Santos, Jesus dos Anjos Vieira e Otávio Rodrigues dos Santos pela disposição, eficiência e companheirismo.

A todos os estagiários que passaram pelo Ambulatório de Aves e pelo Serviço de Cirurgia de Pequenos Animais do HOVET-FMVZ/USP, que ajudaram com os casos clínico-cirúrgicos e pós-operatórios.

À médica veterinária do HOVET-FMVZ/USP Angélica de Mendonça Vaz Safatle pelo seu doutorado que abriu caminho para a pós. 
Às colegas de pós-graduação Ayne, Leda e Thaís pelo convívio, carinho e colaboração.

Aos secretários do Departamento de Cirurgia da FMVZ/USP Belarmino Ney Pereira e Alessandra Aparecida Araújo de Sousa pelo auxílio e dedicação constantes.

Aos funcionários da Biblioteca Virgine Buff D'Ápice da FMVZ/USP pela gentileza e disposição, em particular à bibliotecária Elza Maria Rosa Bernardo Faquim pela orientação durante a fase de elaboração deste trabalho.

Aos funcionários do guichê e da administração do HOVET-FMVZ/USP pelo auxílio quando da solicitação dos prontuários.

Ao meu esposo pelo desenvolvimento do Sistema Gerenciador de Banco de Dados Relacional, pela ajuda com a confecção das tabelas e figuras, pela paciência e amor.

À minha "irmãzinha" Juliana, pelo entusiasmo e carinho, sempre com um sorriso amigo.

À amiga Marluce, pela prontidão em ajudar e torcida constante.

À Cléo, Krika, Bibi e Margot por existirem, alegrando a minha vida e despertando sentimentos bons.

Aos meus pacientes.

A todas as aves. 
"Tu te tornas eternamente responsável por aquilo que cativas"

(Antoine de Saint-Exupéry) 


\section{RESUMO}

CASTRO, P. F. Afecções cirúrgicas em aves: estudo retrospectivo. [Surgical disorders in birds: retrospective study]. 2010. 170f. Dissertação (Mestrado em Ciências) - Faculdade de Medicina Veterinária e Zootecnia, Universidade de São Paulo, São Paulo, 2010.

As aves representam a grande maioria das espécies da fauna silvestre mantidas como animais de companhia em nosso meio e respondem diretamente pela crescente demanda pelo atendimento médico veterinário. O avanço na área da anestesiologia viabilizou a realização de procedimentos cirúrgicos mais longos e complexos e contribuiu para o desenvolvimento e aprimoramento da técnica operatória em aves, contudo, dados nacionais de casuística relacionados às afecções cirúrgicas de aves ainda são inexistentes. Assim, este estudo avaliou retrospectivamente as operações realizadas em aves no Serviço de Cirurgia de Pequenos Animais do Hospital Veterinário da Faculdade de Medicina Veterinária e Zootecnia da Universidade de São Paulo, entre janeiro de 2000 a junho de 2008, com o objetivo de identificar as afecções cirúrgicas, apresentar sua ocorrência e distribuição de freqüência segundo as ordens e espécies acometidas, avaliar as técnicas operatórias empregadas e comparar os dados obtidos com os achados da literatura. De um total de 90 operações realizadas para diagnóstico e/ou tratamento de afecções, 27 foram ortopédicas e 63 de tecidos moles. Quanto ao percentual de operações ortopédicas realizadas segundo as diferentes ordens, observou-se: Psittaciformes 85,19\%, Piciformes 7,41\%, Anseriformes 3,70\% e Falconiformes $3,70 \%$. Para as operações de tecidos moles os psitaciformes representaram $92,06 \%$, columbiformes 3,17\%, passeriformes 3,17\% e anseriformes 1,59\%. Entre os tipos de afecções ortopédicas encontradas as fraturas apresentaram a maior ocorrência (88,89\%), seguidas de luxação (3,70\%), avulsão traumática de extremidade $(3,70 \%)$ e artrite/osteomielite $(3,70 \%)$, o membro pélvico foi o mais acometido e o tibiotarso o osso mais fraturado. Dentre as afecções cirúrgicas de tecidos moles as neoplasias apresentaram a maior ocorrência (30,16\%), seguida das neoformações cutâneas ou de anexos não neoplásicos $(17,46 \%)$, neoformações cutâneas sem diagnóstico (7,94\%), distocia (7,94\%), fístula de papo (7,94\%), hérnia 
abdominal $(4,76 \%)$, sinusite $(4,76 \%)$, gangrena de extremidade de membros $(3,17 \%)$, perfuração de esôfago (3,17\%), prolapso de cloaca $(3,17 \%)$, "Necrose avascular de dígito" (1,59\%), ferida na região da quilha (1,59\%), perfuração de cavidade celomática (1,59\%), neoformação em cavidade celomática sem diagnóstico (1,59\%), corpo estranho em trato gastrointestinal (1,59\%) e otite (1,59\%). O lipoma foi a neoplasia e o cáseo a neoformação não neoplásica mais freqüentes. A distribuição das afecções cirúrgicas segundo as espécies acometidas mostrou o "grupo dos papagaios", representado em sua maioria por espécies do gênero Amazona, como prevalente. A fixação interna com pino intramedular foi a técnica operatória mais utilizada nas afecções cirúrgicas ortopédicas e apresentou elevado índice de retorno à função para tratamento das fraturas. A exérese foi a técnica operatória mais utilizada nas afecções cirúrgicas de tecidos moles e mostrou índices elevados de cura e baixa ocorrência de recidivas. O conhecimento das afecções cirúrgicas e das espécies de aves mais acometidas, bem como dos resultados obtidos com as técnicas operatórias empregadas, acrescentam informações para aqueles que já atuam nesta área e servem como indicador de estudo para futuros cirurgiões de aves.

Palavras-chave: Cirurgia veterinária. Ortopedia. Tecidos moles. Animais silvestres. Psittaciformes. 


\section{ABSTRACT}

CASTRO, P. F. Surgical disorders in birds: retrospective study. [Afecções cirúrgicas em aves: estudo retrospectivo]. 2010. 170f. Dissertação (Mestrado em Ciências) - Faculdade de Medicina Veterinária e Zootecnia, Universidade de São Paulo, São Paulo, 2010.

Birds represent one of the main wildlife species kept as pets in our country and respond directly by the growing demand for health care veterinarian. Advancement in the field of anesthesiology has enabled the surgical procedures longer and more complex and contributed to the development and refinement of surgical technique in birds. However, national data series related to surgical disorders in birds are still poor. This study assessed retrospectively the avian operations at the Service of Small Animal Surgery - Veterinary Hospital of the School of Veterinary Medicine and Animal Science of the University of São Paulo, from January 2000 to June 2008. The focus was to identify the surgical disorders, occurrence and frequency distribution according to orders and species affected, also we evaluated the surgical techniques employed and compared the results with the literature findings. A total of 90 operations were performed for diagnosis or treatment of surgical disorders. Of these 27 were orthopedic and 63 soft tissue surgeries. Considering the orthopedic surgeries performed according to orders we observed: Psittaciformes 85,19\%, Piciformes 7,41\%, Anseriformes 3,70\% and Falconiformes 3,70\%. And for the soft tissues operations the Psittaciformes represented 92,06\%, Columbiformes 3,17\%, Passeriformes 3,17\% and Anseriformes 1,59\%. Fractures presented the highest incidence among orthopedic disorders (88,89\%), followed by luxation $(3,70 \%)$, traumatic avulsion of the end (3,70\%) and arthritis/osteomyelitis (3,70\%). The pelvic limb was the most affected member and the tibiotarsus was the most commonly fractured bone. Among the surgical disorders of soft tissue, neoplasms accounted for $30,16 \%$, followed by cutaneous neoformation or annexes nonneoplastic $(17,46 \%)$, cutaneous neoformations undiagnosed (7,94\%), dystocia $(7,94 \%)$, fistula crop (7,94\%), abdominal hernia (4,76\%), sinusitis (4,76\%), gangrene of the extremity members $(3,17 \%)$, esophageal perforation $(3,17 \%)$, prolapse of cloaca $(3,17 \%)$, "avascular necrosis of digit" (1,59\%), wound in the region of the keel $(1,59 \%)$, 
perforation of the coelomic cavity $(1,59 \%)$, neoformation in the coelomic cavity without a diagnosis $(1,59 \%)$, foreign body in the gastrointestinal tract $(1,59 \%)$ and otitis (1,59\%). Lipoma and caseous were the most frequent cancer and nonneoplastic neoformation observed, respectively. The distribution of surgical disorders according to species affected showed that the "group of parrots", mainly represented by species of Amazonas genus, was prevalent. Internal fixation with intramedullary pin was the technique most often used in orthopedic surgical disorders and showed a high rate of recovery of limb function. The excision was the technique mostly used in the surgical disorders of soft tissue and presented high rates of cure and low recurrence. Knowledge of surgical and bird species most affected, and the results obtained with the surgical techniques employed, add information for those who works in this area and will be an indicator for future surgeons of birds.

Key words: Veterinary surgery. Orthopedics. Soft tissues. Wild animals. Psittaciformes. 


\section{LISTA DE ILUSTRAÇÕES}

Quadro 1 - Diferenças anatômicas entre aves e mamíferos ..............................42

Quadro 2 - Classificação de fraturas em aves ........................................77

Gráfico 1 - Distribuição percentual do total de operações em aves segundo as ordens - São Paulo - janeiro de 2000 a junho de 2008

Figura 1 - Fratura fechada simples de tibiotarso direito em arara-canindé (Ara ararauna). (A) Detalhe da imagem radiográfica do tibiotarso fraturado em sua porção médio distal em projeção lateral. (B) Trans-operatório: foco da fratura com fragmentos ósseos justapostos. (C) Trans-operatório: foco da fratura após sua redução e estabilização. (D) Hematoma e sutura cutânea aos sete dias de pós-operatório. (E) Imagem radiográfica em projeção lateral do tibiotarso consolidado com presença de pino IM e (F) paciente com apoio normal do membro operado, aos 67 dias de pós-operatório (Caso n¹0)

Figura 2 - Fratura fechada simples de úmero esquerdo em papagaio (Amazona sp.). (A) Paciente com asa esquerda caída. (B) Imagem radiográfica do úmero fraturado em terço médio em projeção lateral. (C) Trans-operatório: foco da fratura durante sua redução e estabilização com pino IM. (D) Imagem radiográfica ventro-dorsal do úmero aos 15 dias de pós-operatório com visualização de pino IM, manutenção do eixo e calo ósseo em evolução. (E) Paciente exibe posicionamento normal da asa operada e a $(F)$ imagem radiográfica mostra a presença do pino IM e consolidação óssea em projeção ventro-dorsal, aos 80 dias de pós-operatório (Caso $n^{0} 13$ )

Figura 3 - Fratura fechada dupla de fêmur esquerdo em tucano-toco (Ramphastos toco). (A) Imagem radiográfica da fratura dupla de fêmur em projeção ventro-dorsal e (B) lateral. (C) Radiografia em projeção lateral na qual se visualiza o pino IM e a redução da fratura com manutenção do eixo ósseo do fêmur, 24 horas após a realização da osteossíntese. (D) Imagem radiográfica do pino IM e calo ósseo em evolução no fêmur em projeção ventro-dorsal e (E) paciente apresentando apoio normal do membro operado, 28 dias após a realização do procedimento cirúrgico (Caso n²0) ....97 
Figura 4 - $\quad$ Fratura exposta dupla de úmero esquerdo em carcará (Caracara plancus). (A) Imagem radiográfica do úmero fraturado em terço proximal e distal em projeção ventro-dorsal. (B) Paciente anestesiado e posicionado em decúbito ventral e sítio operatório preparado para a osteossíntese. (C) Trans-operatório: foco da fratura distal com fragmentos ósseos justapostos. (D) Transoperatório: fratura distal reduzida com visualização de pino de aço transfixante e foco da fratura proximal com desvio dos fragmentos ósseos. (E) Trans-operatório: polímero de mamona sendo introduzido no canal medular de um dos fragmentos ósseos da fratura proximal. (F) Trans-operatório: estabilização das fraturas com transfixador externo unipolar (Caso $\left.\mathrm{n}^{\circ} 24\right)$

Figura 5 - Continuação da figura 4: fratura exposta dupla de úmero esquerdo em carcará (Caracara plancus). (A) Trans-operatório: fixador externo unipolar confeccionado com barra de conexão de polimetilmetacrilato e síntese cutânea padrão ponto-simplesseparado. (B) Imagem radiográfica do úmero em projeção ventrodorsal realizada no pós-operatório imediato que mostra redução adequada da fratura dupla com eixo ósseo mantido. (C) Bandagem de contenção da asa aos sete dias de pós-operatório. (D) Imagem radiográfica do úmero em projeção ventro-dorsal realizada no $30^{\circ}$ dia de pós-operatório com visualização dos implantes e calo ósseo em foco proximal e distal da fratura. (E) Imagem radiográfica do úmero em projeção ventro-dorsal após ter sido retirado o transfixador externo, com manutenção do eixo ósseo e (F) paciente exibindo amplitude normal da asa operada, aos 33 dias de pós-operatório (Caso $\left.n^{\circ} 24\right)$

Figura 6 - Fotografias de neoplasias de tecidos moles em aves do gênero Amazona. (A) Lipoma pericloacal em A. aestiva. (B) Lipoma na cauda de Amazona sp. (C) Linfoma cutâneo em $A$. aestiva. (D) Hemangiossarcoma bem diferenciado em membro pélvico de $A$. aestiva

Figura 7 - Fotografias de neoformações cutâneas ou de anexos não neoplásicos em aves da espécie papagaio-verdadeiro (Amazona aestiva). (A) Cáseo. (B) Cisto infundibular ("cisto de pena") em carúnculo

Figura 8 - $\quad$ Sinusite em papagaio-de-cara-roxa (Amazona brasiliensis ${ }^{\star}$ ). (A) Pré-operatório imediato: distensão de seio nasal direito. (B) Trans-operatório: ferida cirúrgica para acesso ao seio nasal com visualização de material caseoso. (C) Detalhe do material caseoso drenado. (D) Pós-operatório imediato: ferida cirúrgica limpa (Caso $\mathrm{n}^{0}$ 18) 
Figura 9 - Ferida traumática na região da quilha em papagaio-verdadeiro (Amazona aestiva). (A) Pré-operatório imediato: ferida tricotomizada. (B) Pós-operatório imediato: síntese cutânea padrão ponto-simples-separado com náilon 5-0 (Caso n 23 )

Figura 10 - CE em trato gastrointestinal de papagaio-verdadeiro (Amazona aestiva). (A) Imagem radiográfica em projeção ventro-dorsal do trânsito gastrointestinal na qual nota-se a presença de estrutura tubular em proventrículo e ventrículo. (B) Pré-operatório imediato: região do papo preparada para ingluviotomia. (C) Endoscopia: visualização do CE (sonda de alimentação) em proventrículo. (D) CE sendo retirado pelo inglúvio após sua apreensão com pinça de endoscopia (Caso $n^{\circ} 44$ )

Figura 11 - Fístula de papo em papagaio-verdadeiro (Amazona aestiva). (A) Fístula inglúvio-cutânea cujas bordas encontram-se parcialmente cobertas por resíduo alimentar. (B) Trans-operatório: incisão das bordas da fístula com separação de pele e inglúvio. (C) Transoperatório: inglúvio suturado em padrão invertido Cushing camada única com fio poliglactina 910 5-0. (D) Pós-operatório imediato: síntese cutânea padrão ponto-simples-separado (Caso $\left.\mathrm{n}^{\circ} 45\right)$

Figura 12 - Lipoma em membro pélvico e pericloacal em papagaio (Amazona sp.). (A) Paciente com neoformação ulcerada e de aspecto pendular em região caudal. (B) Pós-operatório imediato: síntese cutânea padrão ponto-simples-separado com fio poliglactina 910 4-0 em face lateral e (C) em face medial de membro pélvico e pericloacal. (D) Síntese e (E) cicatrização cutânea após a retirada dos pontos, aos 15 dias de pós-operatório (Caso $n^{0} 53$ ) 


\section{LISTA DE TABELAS}

Tabela 1 - Distribuição numérica (N) e percentual (\%) das 87 aves operadas segundo a taxonomia (AVIBASE, 2009; CBRO, 2009) - São Paulo - janeiro de 2000 a junho de 2008

Tabela 2 - Distribuição numérica $(\mathrm{N})$ e percentual (\%) quanto ao tipo e membro acometido do total de afecções cirúrgicas ortopédicas das aves operadas - São Paulo - janeiro de 2000 a junho de 2008

Tabela 3 - Distribuição numérica $(N)$ e percentual (\%) quanto ao membro acometido e presença de comunicação externa das 24 fraturas das aves operadas - São Paulo - janeiro de 2000 a junho de 2008

Tabela 4 - Distribuição numérica $(\mathrm{N})$ e percentual (\%) quanto ao membro acometido e número de linhas de fratura das 24 fraturas das aves operadas - São Paulo - janeiro de 2000 a junho de 2008

Tabela 5 - Distribuição numérica $(\mathrm{N})$ e percentual (\%) do total de afecções cirúrgicas ortopédicas das aves operadas segundo o osso elou articulação acometidos e descrição obtida - São Paulo janeiro de 2000 a junho de 2008

Tabela 6 - Distribuição numérica (N) e percentual (\%) do total de afecções cirúrgicas ortopédicas de aves operadas segundo as ordens São Paulo - janeiro de 2000 a junho de 2008

Tabela 7 - Distribuição numérica (N) e percentual (\%) quanto ao tipo das 23 afecções cirúrgicas ortopédicas operadas em psitaciformes segundo as espécies - São Paulo - janeiro de 2000 a junho de 2008

Tabela 8 - Distribuição numérica $(\mathrm{N})$ e percentual (\%) quanto ao tipo de técnica operatória utilizada nas aves operadas segundo as afecções ortopédicas - São Paulo - janeiro de 2000 a junho de 2008

Tabela 9 - Distribuição dos 16 casos avaliados quanto aos resultados obtidos com as técnicas operatórias para afecções ortopédicas utilizadas nas aves - São Paulo - janeiro de 2000 a junho de 2008 
Tabela 10 - Distribuição numérica $(\mathrm{N})$ e percentual (\%) quanto ao tipo do total de afecções cirúrgicas de tecidos moles das aves operadas - São Paulo - janeiro de 2000 a junho de 2008

Tabela 11 - Distribuição numérica $(\mathrm{N})$ e percentual (\%) quanto ao diagnóstico histopatológico das 19 neoplasias de tecidos moles das aves operadas - São Paulo - janeiro de 2000 a junho de 2008

Tabela 12 - Distribuição numérica $(\mathrm{N})$ e percentual (\%) quanto ao diagnóstico histopatológico das 11 neoformações cutâneas ou de anexos não neoplásicos de tecidos moles das aves operadas - São Paulo - janeiro de 2000 a junho de 2008

Tabela 13 - Distribuição numérica $(\mathrm{N})$ e percentual (\%) do total de casos de afecções cirúrgicas de tecidos moles de aves operadas segundo descrição obtida e localização - São Paulo - janeiro de 2000 a junho de 2008

Tabela 14 - Distribuição numérica $(\mathrm{N})$ e percentual (\%) dos casos de afecções cirúrgicas de tecidos moles de aves operadas segundo as ordens - São Paulo - janeiro de 2000 a junho de 2008 106

Tabela 15 - Distribuição numérica $(\mathrm{N})$ e percentual (\%) quanto ao tipo das 58 afecções cirúrgicas de tecidos moles operadas em psitaciformes segundo as espécies - São Paulo - janeiro de 2000 a junho de 2008

Tabela 16 - Distribuição numérica $(\mathrm{N})$ e percentual (\%) quanto ao tipo de técnica operatória utilizada nas aves operadas segundo as afecções de tecidos moles - São Paulo - janeiro de 2000 a junho de 2008

Tabela 17 - Distribuição dos 53 casos avaliados quanto aos resultados obtidos com as técnicas operatórias para afecções de tecidos moles utilizadas nas aves - São Paulo - janeiro de 2000 a junho de 2008 


\section{LISTA DE ABREVIATURAS E SIGLAS}

$\begin{array}{ll}\text { CATB } & \begin{array}{l}\text { cultura e antibiograma } \\ \text { CE }\end{array} \\ \text { FMVZ/USP } & \begin{array}{l}\text { Faculdade de Medicina } \\ \text { Universidade de São Paulo }\end{array} \\ \text { HOVET-FMVZ/USP } & \begin{array}{l}\text { Hospital Veterinário da Faculdade de Medicina Veterinária e } \\ \text { Zootecnia da Universidade de São Paulo }\end{array} \\ \text { HP } & \text { histopatológico(s) } \\ \text { IM } & \text { intramedular } \\ \text { K-E } & \text { Kirschner-Ehmer } \\ \text { N } & \text { distribuição numérica } \\ \text { SGBDR } & \text { Sistema Gerenciador de Banco de Dados Relacional }\end{array}$




\section{LISTA DE SÍMBOLOS}

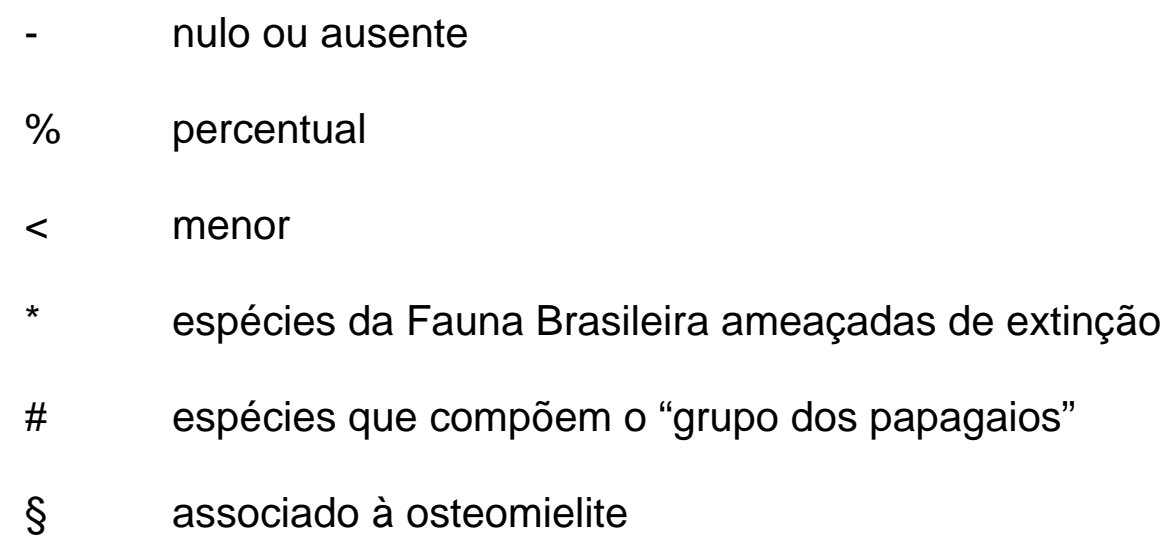





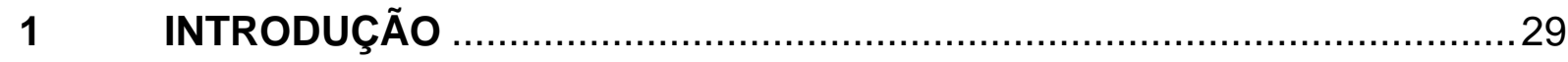

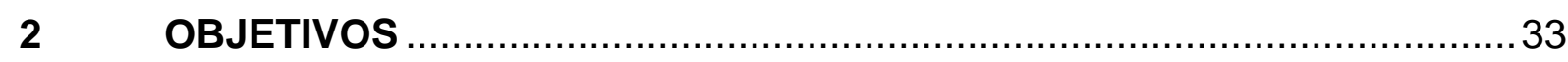

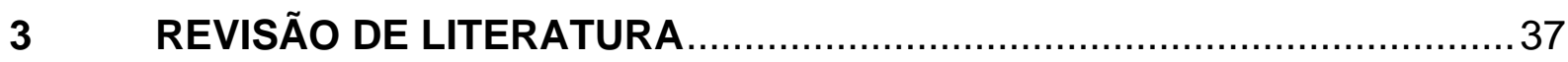

3.1 CLASSIFICAÇÃO TAXONÔMICA ....................................................... 37

3.2 AVES COMO "ANIMAIS DE ESTIMAÇÃO” ......................................... 38

3.3 EVOLUÇÃO DA ANESTESIA E OPERAÇÃO EM AVES ..........................40

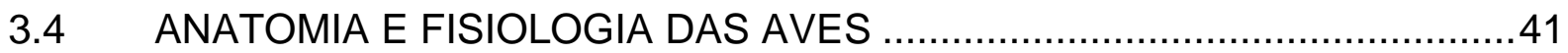

3.5 PRINCÍPIOS DA TÉCNICA CIRÚRGICA EM AVES ..............................45

3.6 AFECÇÕES CIRÚRGICAS ORTOPÉDICAS DAS AVES $\ldots \ldots \ldots \ldots \ldots \ldots \ldots \ldots . . . \ldots \ldots$

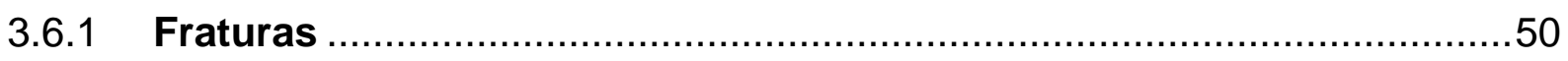

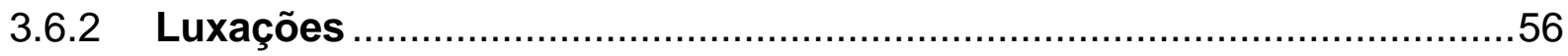

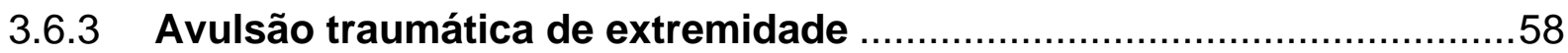

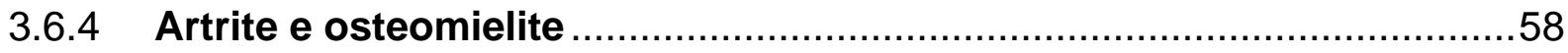

3.7 AFECÇÕES CIRÚRGICAS DE TECIDOS MOLES DAS AVES ..................59

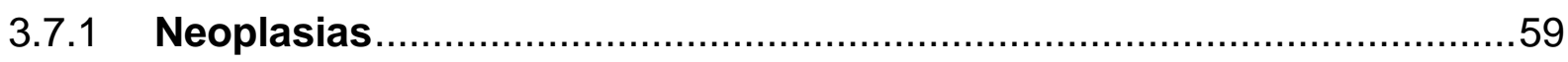

3.7.2 Neoformações cutâneas ou de anexos não neoplásicas .......................62

3.7.3 “Necrose avascular de dígito".................................................64

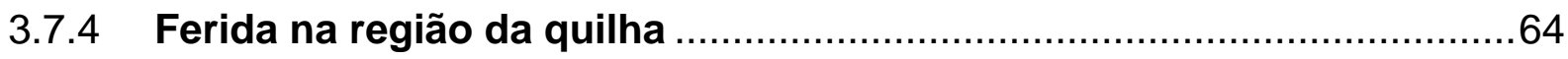

3.7.5 Gangrena de extremidade de membros ....................................65

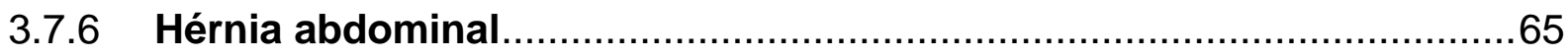

3.7.7 Perfuração de cavidade celomática ............................................66

3.7.8 Neoformação em cavidade celomática ..........................................66

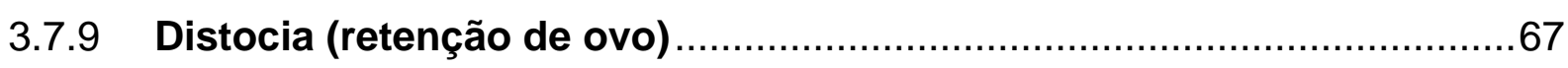

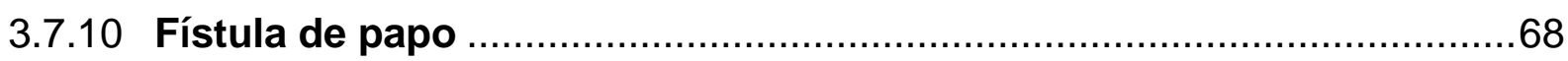

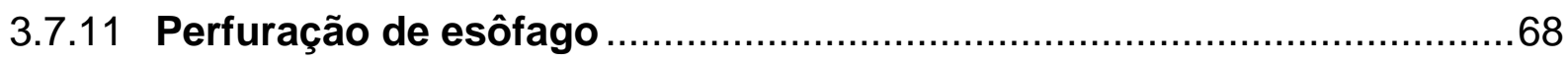

3.7.12 Corpo estranho em trato gastrointestinal ...................................69

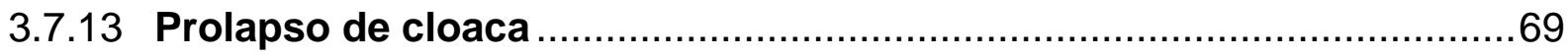

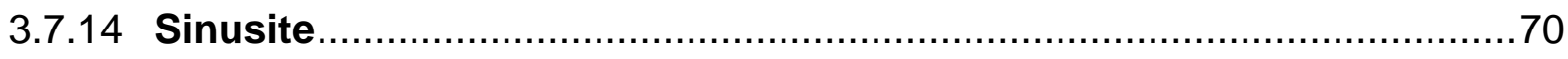

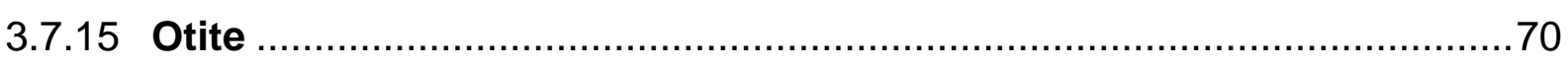

3.8 AFECÇÕES CIRÚRGICAS SEGUNDO A TAXONOMIA .........................71

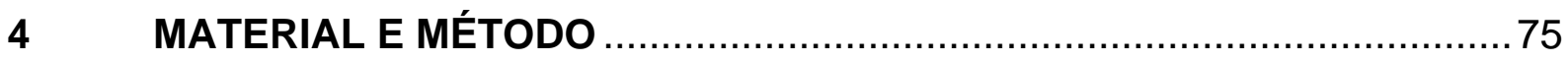

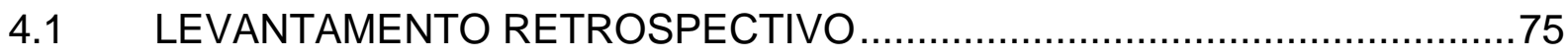




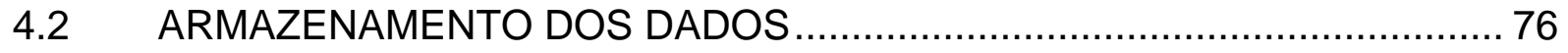

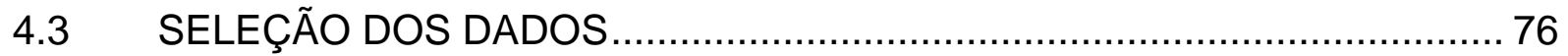

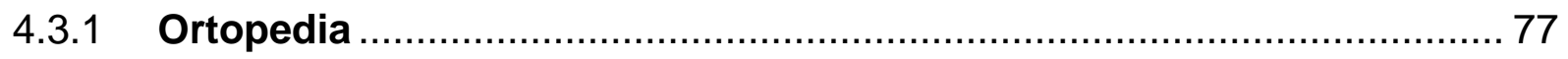

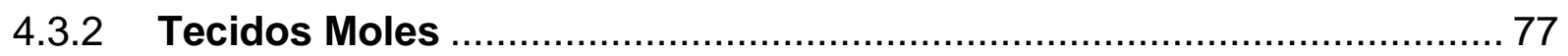

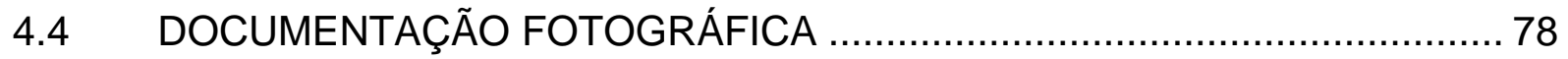

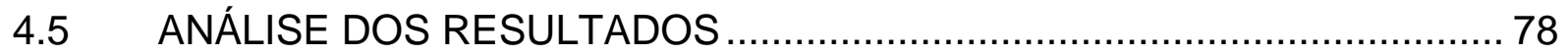

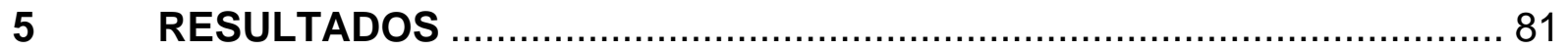

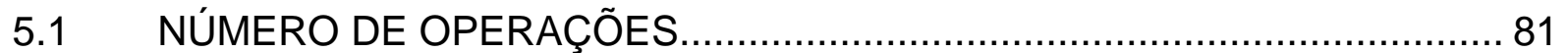

5.2 NÚMERO DE ANIMAIS E CLASSIFICAÇÃO TAXONÔMICA...................... 81

5.3 DISTRIBUIÇÃO DAS OPERAÇÕES SEGUNDO AS ORDENS ................... 83

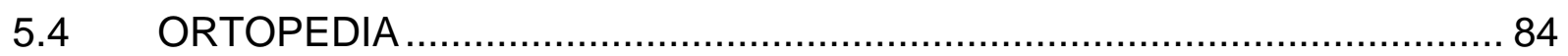

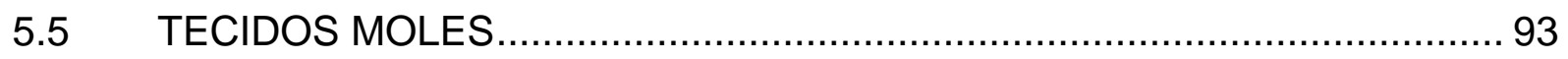

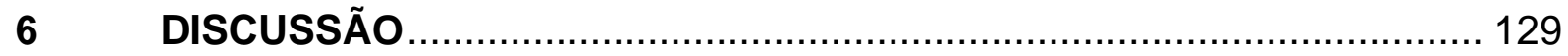

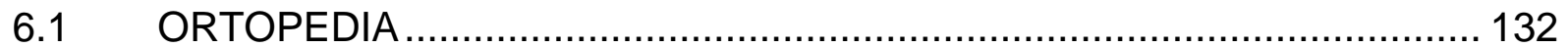

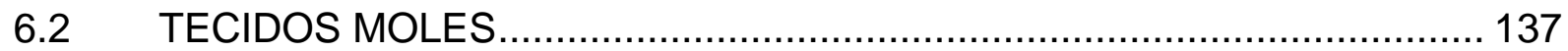

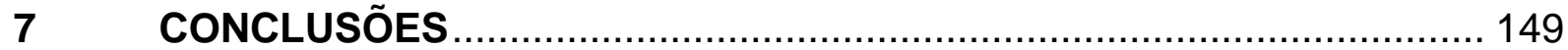

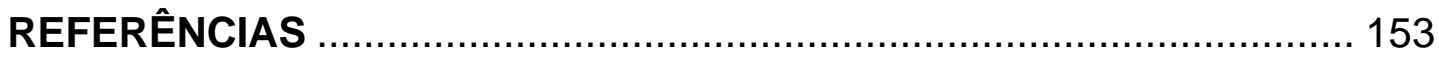

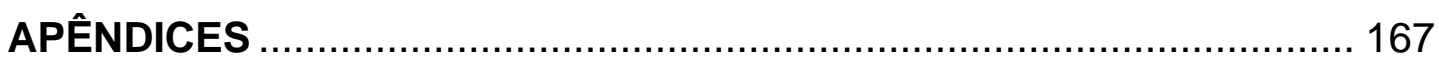


INTRODUÇÃO 


\section{INTRODUÇÃO}

As aves representam a maioria das espécies da fauna silvestre mantidas como animais de companhia em nosso meio, infelizmente grande parte proveniente do tráfico. Este fato associado ao aumento da popularidade dos animais exóticos como animais de estimação, resultaram numa demanda crescente pelo atendimento clínico e cirúrgico prestado pelo médico veterinário a esta classe de animais (FOTIN, 2005).

A medicina de aves, excluindo-se a avicultura, tem uma história muito curta se comparada com outras subdisciplinas da medicina veterinária; a anestesia e a operação de pássaros de companhia eram quase desconhecidas até o final dos anos 60. O desenvolvimento e o aprimoramento da técnica operatória em aves estão intimamente relacionados ao avanço na área da anestesiologia, observado após a introdução do isofluorano como agente anestésico para pássaros em 1985 por Greg Harrison. A partir daí, viabilizou-se a realização de procedimentos cirúrgicos mais longos e complexos (ALTMAN, 1998).

Atualmente a literatura internacional em clínica de aves é vasta, porém reflete em sua maioria estudos conduzidos em espécies da sua fauna, enquanto a literatura nacional ainda é escassa, restrita a poucas publicações. Diante desta lacuna, notase a importância crescente de obtenção de dados nacionais quantitativos e qualitativos nas áreas afins.

O levantamento retrospectivo de dados relacionados a afecções cirúrgicas em aves contribuirá para o conhecimento das enfermidades mais freqüentes nas diferentes espécies e das técnicas operatórias para tratá-las, levando informações para o clínico ou cirurgião atuante nesta área. 

OBJETIVOS 



\section{OBJETIVOS}

Neste estudo foram analisados os prontuários das aves que foram submetidas a intervenções cirúrgicas no Serviço de Cirurgia de Pequenos Animais do Hospital Veterinário da Faculdade de Medicina Veterinária e Zootecnia da Universidade de São Paulo (HOVET-FMVZ/USP), no período compreendido entre janeiro de 2000 a junho de 2008, com os seguintes objetivos:

$>$ identificar as diferentes afecções cirúrgicas em aves e apresentar sua ocorrência;

$>$ estabelecer sua distribuição de freqüência segundo as ordens e espécies acometidas;

avaliar os resultados obtidos com as técnicas operatórias empregadas;

comparar os dados obtidos com as informações constantes na literatura. 

REVISÃO DE LITERATURA 



\section{REVISÃO DE LITERATURA}

\subsection{CLASSIFICAÇÃO TAXONÔMICA}

A classificação científica dos animais pertence ao campo da Taxonomia, a qual é fundamentada, principalmente, na morfologia e anatomia dos seres vivos estudados. A classe é dividida em ordens para expressar um parentesco mais próximo entre os animais. As ordens são divididas em famílias, as quais são baseadas em dados sobre origem, relações de parentesco, morfologia e etologia para classificação dos seres. A próxima entidade é o gênero, cuja interpretação pode ser subjetiva, sofrendo alterações segundo o surgimento de novos conceitos. A espécie é representada pelo indivíduo, o elemento básico na classificação (SICK, 1997).

A classe Aves é subdividida em aproximadamente 27 ordens, 160 famílias e cerca de 1800 gêneros. Outras subdivisões às vezes são reconhecidas, tais como subclasses, superordens, subordens, tribos e subfamílias (DILGER, 1982). A ordem Passeriformes é a maior delas, possui 5739 diferentes espécies (SICK, 1997).

O termo psitacídeo é aceito e amplamente usado para designar qualquer das espécies que pertençam à família Psittacidae (FORBES; LAWTON, 1996) ou de forma mais abrangente, à ordem Psittaciformes (CUBAS; GODOY, 2007).

O total de aves para todo o mundo é estimado em 9700 espécies (O'MALLEY, 2005). Para o conhecimento dos aspectos biológicos das diferentes espécies de aves recomenda-se a consulta em literatura especializada (ALTMAN et al., 1997; FOWLER; CUBAS, 2001; CUBAS; SILVA; CATÃO-DIAS, 2007). 


\subsection{AVES COMO “ANIMAIS DE ESTIMAÇÃO”}

A manutenção de aves como "animais de companhia" por sua beleza, coloração e habilidade para cantar e falar é universal em todas as sociedades humanas e data de milhares de anos (WISE, 1984). Historicamente espécies silvestres acompanham a sociedade brasileira desde a época colonial, costume introduzido pelas tribos indígenas (SICK, 1997).

O Brasil encontra-se entre os países de maior riqueza de fauna do mundo; ocupa a primeira posição em número total de espécies (RENCTAS, 2001) e a terceira em espécies de aves com aproximadamente 1677 espécies, sendo 1524 residentes e 153 visitantes (SICK, 1997). Possui o maior número de espécies de psitacídeos do planeta, das 358 espécies existentes no mundo (GILL, 1995), 83 são brasileiras (CBRO, 2009). Esta riqueza foi referência ao país, quando em 1500 foi designado como a "Terra dos Papagaios" (Brasilia sive terra papagallorum). Infelizmente esta diversidade vem diminuindo. Um exemplo disto é o da ararinhaazul (Cyanopsitta spixii), que em 1985 encontrava-se representada por apenas três exemplares na região de Curaça (Bahia), e hoje é considerada extinta da natureza (GALETTI; PIZO, 2002).

As principais aves de companhia, segundo Burr (1987), pertencem às ordens Psittaciformes, Passeriformes, Galliformes, Anseriformes, Columbiformes, Falconiformes e Strigiformes; para Forbes e Lawton (1996), pertencem às ordens Psittaciformes e Passeriformes. Dilger (1982) considera o periquito-australiano (Melopsittacus undulatus) a mais popular ave de gaiola mantida como "pet", seguido pelo canário (Serinus canarius), enquanto para Cubas e Godoy (2007), a ordem Passeriformes é a mais popular.

Gondim, Gomes e Maia (2006) em sua casuística de aves atendidas de 2002 a 2004 na Universidade Federal da Bahia, observaram a maior prevalência de atendimento a papagaios (39,31\%) seguido de periquitos-australianos (20\%), sendo que os canários responderam por $17,24 \%$ das consultas. Foi verificado neste estudo que $100 \%$ das aves nativas atendidas foram adquiridas através do comércio ilegal.

Um levantamento das doenças diagnosticadas em aves atendidas no hospital veterinário da Universidade Federal do Paraná, entre o período de 2003 a 2006, mostrou as maiores ocorrências na ordem Psittaciformes $(43,48 \%)$ seguida da 
Passeriformes (26,88\%), e nas espécies canário (Serinus canarius) (15,93\%) seguido do papagaio-verdadeiro (Amazona aestiva) (12,36\%) (SANTOS et al., 2008).

De acordo com Fotin (2005), as aves representam a maioria das espécies da fauna silvestre mantidas como animais de companhia em nosso meio, infelizmente quase que em sua totalidade provenientes do tráfico, apesar da regulamentação pela legislação brasileira da sua reprodução e comercialização (BRASIL, 1997). Em pesquisa realizada e publicada pela Rede Nacional de Combate ao Tráfico de Animais Silvestres, o tráfico de animais silvestres é responsável pela retirada anual estimada de cerca de 38 milhões de espécimes da natureza em nosso país, sendo as aves os animais encontrados em maior proporção no comércio ilegal (RENCTAS, 2001).

O Brasil está entre os cinco primeiros países com maior número de aves e mamíferos ameaçados de extinção (BAILLIE; GROOBRIDGE, 1996) e o grupo dos psitacídeos, muito procurado como animais de estimação devido a sua inteligência e habilidade em imitar sons humanos (FORBES; LAWTON, 1996), é aquele com maior número de espécies descritas na Lista das Espécies da Fauna Brasileira Ameaçadas de Extinção do Ministério do Meio Ambiente (SICK, 1997; BRASIL, 2003a; b). 


\subsection{EVOLUÇÃO DA ANESTESIA E OPERAÇÃO EM AVES}

A medicina de aves, excluindo-se a avicultura, tem uma história muito curta se comparada com outras subdisciplinas da medicina veterinária. Referências à anestesia e operação de aves foram raras na literatura até o final de 1940, sendo a primeira referência de procedimento cirúrgico realizado em pássaros de gaiola encontrada na edição de 1943 de Stroud's digest on the diseases of birds, de autoria de Robert Stroud. Em 1947, Irving E. Altman escreveu um artigo para o Veterinary excerpts, descrevendo as técnicas de imobilização com talas para fraturas em pássaros que são utilizadas até hoje, o primeiro artigo na área de cirurgia em pássaros de companhia escrito por um veterinário que se tem conhecimento (ALTMAN, 1998). José Reis publicou em 1945 um manual prático para criadores, estudantes e técnicos no qual abordou o tema "Como se operam aves", a primeira referência literária brasileira encontrada nesta área.

O desenvolvimento e o aprimoramento da operação de aves estão intimamente relacionados ao avanço na área da anestesiologia. Antes, e no começo do século $X X$, a maioria dos procedimentos cirúrgicos veterinários de pequeno porte era realizada sem anestesia. Entre 1930 e 1940, o uso do éter em máscaras faciais abertas ofereceu aos veterinários cirurgiões a oportunidade de realizar procedimentos mais demorados. O pentobarbital sódico tornou-se viável no início de 1950, porém apesar de induzir longos períodos de anestesia, também resultava em longos períodos de recuperação e alta taxa de mortalidade. Este fato desestimulou muitos veterinários a realizarem operação em pássaros (ALTMAN, 1998).

Em 1956 Charles Gandal, veterinário do Bronx Zoo, introduziu uma combinação anestésica injetável mais segura e com menor período de recuperação, associando ao pentobarbital sódico, hidrato de cloral, propileno glicol e álcool etílico. Em 1961 éter era misturado com o ar da sala usando um vaporizador desenvolvido para este fim. Em 1965 ou 1966, vaporizadores desenvolvidos para anestesia humana foram usados com metoxifluorano e oxigênio para anestesiar pássaros e, no período subseqüente o halotano foi gradativamente substituindo o metoxifluorano como anestésico de escolha para pássaros, devido ao menor tempo de indução e recuperação e menor taxa de mortalidade durante e após as operações. Porém, só após a introdução do isofluorano como agente anestésico para pássaros em 1985 
por Greg Harrison, observou-se um real avanço na área da cirurgia em aves. A partir daí, viabilizou-se a realização de procedimentos cirúrgicos mais longos e complexos (ALTMAN, 1998).

A formação da Association of Avian Veterinarians em 1980 foi sem dúvida o maior passo para a disseminação de informações em anestesia e operação de aves. Desde então diversos livros (COLES, 1985; HARRISON; HARRISON, 1986; BURR, 1987; RITCHIE; HARRISON; HARRISON, 1994; ROSSKOPF; WOERPEL, 1996; ALTMAN et al., 1997; HARRISON; LIGHTFOOT, 2006) e periódicos como o Journal of Avian Medicine and Surgery e tantos outros de medicina veterinária vêm contribuindo para a formação daqueles que se interessam por estas áreas. A literatura nacional veterinária ainda é restrita e encontra-se representada pela publicação recente de um livro que contempla as áreas da anestesia e cirurgia em aves como parte do seu conteúdo (CUBAS; SILVA; CATÃO-DIAS, 2007). Especificamente na área de interesse do nosso estudo, a operação de aves, o número de teses, trabalhos científicos apresentados em congressos e publicações em periódicos ainda é bastante reduzido.

\subsection{ANATOMIA E FISIOLOGIA DAS AVES}

Aspectos anatômicos e fisiológicos considerados relevantes para o estudo da cirurgia em aves serão abordados a seguir.

Anatomicamente as aves podem ser caracterizadas como vertebrados emplumados, primariamente especializados em voar. Filogeneticamente são mais primitivos que os mamíferos, portanto possuem características de afinidade com os seus progenitores, os répteis. Diversos sistemas orgânicos são completamente diferentes, estrutural e funcionalmente, dos seus homólogos em mamíferos. No quadro 1 são apresentadas algumas das diferenças anatômicas de interesse cirúrgico entre estas duas classes de animais, adaptado de Evans (1982). 
(Continua)

\begin{tabular}{|c|c|}
\hline AVES & MAMÍFEROS \\
\hline \multicolumn{2}{|c|}{ Sistema tegumentar } \\
\hline bico córneo & - \\
\hline cera ou carúnculo $\nabla$ & - \\
\hline penas & pêlos \\
\hline- & glândulas sudoríparas \\
\hline glândula uropigeal & - \\
\hline \multicolumn{2}{|c|}{ Sistema esquelético } \\
\hline $\begin{array}{l}\text { leve, ossos pneumáticos (úmero, clavícula, } \\
\text { coracóide, crânio, coluna vertebral, algumas } \\
\text { costelas, cinto pélvico, fêmur de aves voadoras) }\end{array}$ & pesado, ossos preenchidos por medula \\
\hline crânio cinético & crânio acinético \\
\hline côndilo occipital único & dois côndilos occipitais \\
\hline- & suturas cranianas \\
\hline articulação mandibular entre quadrado e articular & articulação mandibular entre dentário e temporal \\
\hline regiões vertebrais variavelmente fundidas & regiões vertebrais distintas \\
\hline esterno grande em quilha & esterno pequeno e segmentar \\
\hline membros pélvicos com 2 a 4 dígitos & $\begin{array}{l}\text { membros pélvicos usualmente com mais de } 3 \\
\text { dígitos }\end{array}$ \\
\hline $\begin{array}{l}\text { fusão de ossos dos membros: carpometacarpo, } \\
\text { tibiotarso e tarsometatarso }\end{array}$ & $\begin{array}{l}\text { separados: carpo, metacarpo, tíbia, tarso e } \\
\text { metatarso }\end{array}$ \\
\hline sínfise pélvica usualmente ausente & sínfise pélvica sempre presente \\
\hline $\begin{array}{l}\text { clavículas fundidas (ausentes ou vestigiais em } \\
\text { psitacídeos) }\end{array}$ & - \\
\hline osso coracóide grande & - \\
\hline articulação do tornozelo é intratarsal & articulação do tornozelo é intertarsal \\
\hline $\begin{array}{l}\text { vértebras sacrais sem superfícies articulares } \\
\text { amplas }\end{array}$ & $\begin{array}{l}\text { vértebras sacrais com superfícies articulares } \\
\text { amplas }\end{array}$ \\
\hline púbis direcionado caudalmente & púbis direcionado cranialmente \\
\hline \multicolumn{2}{|c|}{ Sistema muscular } \\
\hline musculatura peitoral é a mais robusta & $\begin{array}{l}\text { musculatura peitoral não apresenta grande } \\
\text { massa muscular }\end{array}$ \\
\hline tendões de membros freqüentemente ossificados & tendões de membros não ossificados \\
\hline musculatura epaxial reduzida e pouco funcional & $\begin{array}{l}\text { grande massa de musculatura epaxial importante } \\
\text { para função locomotora }\end{array}$ \\
\hline \multicolumn{2}{|c|}{ Sistema digestório } \\
\hline- & dentes \\
\hline inglúvio usualmente presente & - \\
\hline estômago em duas partes: glandular e mecânico & estômago usualmente único glandular \\
\hline cloaca & usualmente ausente \\
\hline
\end{tabular}


(Conclusão)

\begin{tabular}{|c|c|}
\hline AVES & MAMÍFEROS \\
\hline \multicolumn{2}{|c|}{ Sistema urogenital } \\
\hline- & vesícula urinária \\
\hline ausente na maioria & pênis \\
\hline postura de ovos & placenta, apenas monotremos põem ovos \\
\hline apenas ovário e oviducto esquerdos funcionais & ovário e oviducto bilaterais funcionais \\
\hline- & glândulas mamárias \\
\hline testículos internos & testículos usualmente externos \\
\hline \multicolumn{2}{|c|}{ Sistema respiratório } \\
\hline- & epiglote \\
\hline- & cordas vocais usualmente presentes \\
\hline siringe & - \\
\hline anéis traqueais completos & anéis traqueais abertos dorsalmente \\
\hline sacos aéreos & - \\
\hline pulmão pequeno, compacto, expande pouco & pulmão grande, alveolar, expande muito \\
\hline \multicolumn{2}{|c|}{ Sistema circulatório } \\
\hline aorta deriva do $4^{\circ}$ arco direito & aorta deriva do $4^{\circ}$ arco esquerdo \\
\hline poucos linfonodos & muitos linfonodos \\
\hline dois sistemas porta (renal e hepático) & apenas sistema porta hepático \\
\hline \multicolumn{2}{|c|}{ Ouvido } \\
\hline- & pavilhão externo \\
\hline ducto coclear curto & ducto coclear enrolado, longo \\
\hline membrana timpânica convexa & membrana timpânica côncava \\
\hline
\end{tabular}

$\nabla$ área ao redor da superfície mais dorsal do bico superior onde se abrem as narinas nos psitacídeos, pode ou não apresentar penas (OROSZ, 1997)

Fonte: Adaptado de EVANS, E. H. Anatomy of the budgerigar. In: PETRAK, M. L. Diseases of cage and aviary birds. 2. ed. Philadelphia: Lea \& Febiger, 1982.

Quadro 1 - Diferenças anatômicas entre aves e mamíferos 
A pele das aves é mais fina, menos elástica e mais delicada que a dos mamíferos, ligada a ossos nas porções distais das asas, pés, crânio e pelve (BAUCK; OROSZ; DORRESTEIN, 1997; COLES, 2007). Apresenta numerosos vasos sanguíneos, tanto capilares como veias de maior calibre (COLES, 2007). As penas primárias e secundárias das asas são ligadas ao periósteo, respectivamente, do metacarpo e da ulna (MARTIN; RITCHIE, 1994). A cicatrização de feridas nas aves segue a mesma seqüência de eventos que a dos mamíferos, com atenção especial à sutura da pele para cicatrização primária diante da falta de tecido subcuticular nas aves (BOWLES et al., 2006).

Adaptado basicamente ao vôo, o esqueleto das aves exibe duas características principais: leveza e resistência aerodinâmica (FEDUCCIA, 1986; LEVITT, 1989).

A leveza deve-se ao processo de pneumatização dos ossos por extensões dos sacos aéreos (FEDUCCIA, 1986) e às corticais ósseas finas e frágeis (LEVITT, 1989), mais eficientes estruturas de resistência às forças de torque impostas ao osso, quando este está sob a pressão de curvatura e torção que ocorrem durante o vôo (COLES, 2007).

A resistência resulta da fusão óssea, perceptível no crânio e cinto pélvico, muitas vezes associada à supressão óssea, como ocorre com os ossos distais da asa e do membro pélvico (FEDUCCIA, 1986) e da presença de um elevado conteúdo mineral que torna os ossos mais "duros" (DYCE; SACK; WENSING, 1997; MARTIN; RITCHIE, 1994). Outra característica importante é a presença de uma rede de trabéculas ósseas no interior do osso, orientadas para contrabalancear com as forças externas impostas em pontos particulares, daí a maior concentração de trabéculas localizar-se nas extremidades ósseas, que são submetidas a stress máximo (COLES, 2007).

Os sacos aéreos são extensões do sistema brônquico que ocupam principalmente a cavidade celomática, junto com as vísceras torácicas e abdominais. Divertículos desses sacos aéreos estendem-se, através de forames pneumáticos, pelas cavidades medulares dos ossos adjacentes (DYCE; SACK; WENSING, 1997), denominados "ossos pneumáticos", cujo canal medular preenchido por ar está envolvido no ciclo respiratório durante o vôo. Estes ossos, ao diminuírem a massa esquelética e facilitarem o vôo, também aumentam o risco de fragmentação óssea 
diante de um trauma (BENNETT, 1997) e o risco de asfixia, saculite ou pneumonia, se fluidos ou debris forem empurrados para o seu interior (MARTIN; RITCHIE, 1994).

O suprimento sanguíneo dos ossos origina-se no periósteo, vindo da musculatura e tecidos moles, do canal medular e dos vasos metafisários e epifisários (MARTIN; RITCHIE, 1994). Estudos histológicos demonstraram que o calo ósseo origina-se de células progenitoras do periósteo, endósteo e tecidos conectivos, confirmando que não existem diferenças entre a consolidação óssea das aves e dos mamíferos, exceto aquelas relacionadas à evolução temporal (NEWTON; ZEITLIN, 1977; ALIEVI, 2000; BOLSON et al., 2008), sendo mais rápida nas aves que nos mamíferos (BLASS, 1987; LEVITT, 1989; BENNETT, 1997). No estudo com pombos conduzido por Bolson et al. (2008), aos 15 dias de pós-operatório a presença de calo foi notada à palpação, a avaliação radiográfica mostrou ausência de linha de fratura com início de formação de calo ósseo e a análise histológica revelou cicatrização moderada com presença de calo ósseo-cartilaginoso, sendo observado radiograficamente remodelação completa a partir dos 90 dias e histologicamente intensa cicatrização e total remodelação aos 120 dias.

Os seios infraorbitários em aves constituem-se de uma série de cavidades e divertículos localizados parcialmente ao redor dos olhos, com variações entre as espécies, cujas paredes laterais são formadas por músculos e não têm cobertura óssea, e que se comunicam através de um seio nasal central (ALTMAN, 1997b).

Os intestinos nas aves não são facilmente mobilizados como nos mamíferos, sendo suspensos tanto dorsal quanto ventralmente pelo mesentério, que se encontra intimamente circundado pelos sacos aéreos abdominais (COLES, 2007). O omento é ausente nas aves, portanto há maior potencial para vazamento de vísceras submetidas à diérese e síntese (ALTMAN, 1997b).

\subsection{PRINCÍPIOS DA TÉCNICA CIRÚRGICA EM AVES}

Como nos mamíferos, a técnica cirúrgica em aves deve ser asséptica e o cirurgião deve estar familiarizado com os procedimentos e a anatomia da espécie em questão. Os procedimentos cirúrgicos devem ser realizados com maior delicadeza e rapidez, se comparados àqueles em mamíferos, devido às diferenças 
anatômicas e fisiológicas entre estas duas classes de animais. Anterior à intervenção cirúrgica a ave deve ser submetida à avaliação física e realizados exames complementares se indicados. A avaliação pré-cirúrgica criteriosa, a monitoração intra-operatória e os cuidados pós-operatórios são decisivos para 0 sucesso terapêutico (ALTMAN, 1997a; CUBAS; GODOY, 2007).

$\mathrm{Na}$ preparação do paciente para a operação deve-se respeitar o período de jejum de duas a 36 horas de acordo com a espécie, para que o trato gastrointestinal se esvazie. Nos casos emergenciais o inglúvio pode ser esvaziado, a intubação realizada em posição ereta e o esôfago obstruído com uma sonda ou gaze para prevenir o refluxo alimentar (RUPLEY, 1999; BOWLES et al., 2006; GODOY, 2007).

Se há indicação de antibioticoterapia, esta deve ser iniciada uma a duas horas antes da cirurgia e mantida por no mínimo oito a 12 horas no pós-operatório (RUPLEY, 1999).

O tamanho relativamente pequeno dos pacientes aviários requer uma atenção cuidadosa para hemostasia e perda de calor. Portanto, para preparar a pele, as penas devem ser arrancadas delicadamente para evitar laceração e hematoma e em quantidade suficiente para a exposição cirúrgica. Se cortadas, as penas não crescerão até a muda seguinte. A remoção excessiva de penas resultará em diminuição do isolamento e aumento na demanda metabólica, assim como o uso de quantidades excessivas de álcool ou outra solução para antissepsia poderá resultar em hipotermia. A perda de calor corporal durante a cirurgia poderá ser minimizada com o uso de fonte de calor suplementar, como bolsas térmicas e lâmpadas aquecedoras e otimização do tempo cirúrgico (GANDAL, 1982; ALTMAN, 1997a; RUPLEY, 1999; BOWLES et al., 2006; COLES, 2007).

Aves posicionadas em decúbito dorsal têm seu volume de ar dos sacos aéreos reduzido, condição exacerbada pela presença de neoformações intrabdominais que ocupem espaço considerável, razão pela qual o decúbito ventral ou lateral deve ser preterido nestes casos (COLES, 2007). Para qualquer celiotomia o paciente deveria ser posicionado com a porção cranial do corpo elevada 30 a $40^{\circ}$ para prevenir que fluídos se desloquem cranialmente e entrem nos pulmões após incisão dos sacos aéreos (BENNETT; HARRISON, 1994; FORBES, 2002).

A preparação da pele para a criação e manutenção de um campo estéril cirúrgico é tão importante nas aves quantos nos mamíferos, e soluções à base de iodo-povidina ou clorexidine são freqüentemente utilizados (ALTMAN, 1997a; 
BOWLES et al., 2006; CUBAS; GODOY, 2007). Altman (1997a) encontrou a formação de granuloma e infecção em pombos submetidos à laparoscopia torácica e abdominal no qual um laparoscópio não estéril fora utilizado.

Os panos de campo, assim como o posicionamento das mãos do cirurgião e dos instrumentos não devem dificultar a respiração da ave. Panos de campo confeccionados com material transparente e leve são os mais indicados, permitem melhor monitoração anestésica do paciente, adequada amplitude respiratória e melhor visualização do campo cirúrgico (RUPLEY, 1999; BOWLES et al., 2006).

Instrumental para microcirurgias ou cirurgias oftálmicas, cotonetes ou swabs estéreis são freqüentemente úteis, assim como lupas de aumento binoculares ou microscópios cirúrgicos (ALTMAN, 1997a; RUPLEY, 1999; BOWLES et al., 2006; CUBAS; GODOY, 2007). Bisturi de radiofreqüência para incisão e coagulação deve preferencialmente ser bipolar por ser mais eficiente em espécies pequenas e com faixa de freqüência de até $5 \mathrm{MHz}$ (COLES, 2007), e utilizado com cautela para prevenir danos excessivos aos tecidos e estruturas adjacentes (GANDAL, 1982).

A seleção do material de sutura dependerá da natureza do tecido a ser suturado, do seu grau de infecção e da magnitude da resposta inflamatória esperada, assim como da resistência do fio, quantidade de nós desejada e seu tempo de absorção, e ainda, da preferência do cirurgião (ALTMAN, 1997a). As suturas com fios 3-0 a 6-0 são comumente utilizadas na operação de aves (RUPLEY, 1999; CUBAS; GODOY, 2007). O categute e a poliglactina 910 causam resposta inflamatória mais exacerbada nesta classe de animais, ao contrário, o náilon, a polidioxanona e o aço causam mínima reação tecidual (RUPLEY, 1999; ALTMAN, 1997a).

Cirurgia é uma modalidade que requer experiência (ALTMAN, 1997b). Em virtude do pequeno tamanho corpóreo e da alta taxa metabólica das aves, a operação nesta classe de animais requer exatidão, pois qualquer erro é magnificado (FORBES, 2002). Recomenda-se o treinamento pelo cirurgião das técnicas cirúrgicas em cadáveres antes de realizá-las em pacientes, bem como a revisão da anatomia e acesso regional da área a ser operada. Os delicados tecidos das aves se rompem na presença de leve autólise, portanto, o uso de cadáveres frescos facilitará a percepção pelo cirurgião das características destes tecidos (BENNETT; HARRISON, 1994). 


\subsection{AFECÇÕES CIRÚRGICAS ORTOPÉDICAS DAS AVES}

Afecções ortopédicas são freqüentes na clínica de pássaros de companhia (HELMER; REDIG, 2006) e incluem aquelas causadas por trauma, deficiências nutricionais, distúrbios metabólicos e infecções (BLASS, 1987). Devido à natureza traumática da maioria, a prioridade deve ser dada à estabilização do paciente (HELMER; REDIG, 2006).

No período de 2000 a 2004, exames radiográficos de 201 aves atendidas no HOVET-FMVZ/USP, portadoras de alterações radiográficas no sistema esquelético, mostraram que as afecções de origem traumática (46,77\%) foram as mais freqüentes, sendo $74,47 \%$ das aves acometidas por fraturas, $25,53 \%$ por luxações e 10,64\% por amputações ósseas, distribuídas segundo as ordens de maior ocorrência em Psittaciformes (68,09\%) com a prevalência do papagaio-verdadeiro (Amazona aestiva) e Passeriformes (11,70\%) (ARNAUT, 2006).

Gondim, Gomes e Maia (2006) observaram que as afecções traumáticas foram aquelas com maior ocorrência nas aves, tendo correspondido a 23,45\% dos casos atendidos. Santos et al. (2008) em seu levantamento das doenças diagnosticadas em aves encontrou as afecções traumáticas $(22,13 \%)$ como as mais freqüentes, dentre as quais as fraturas representaram $30,91 \%$ e as luxações $9,1 \%$.

As características anatômicas e fisiológicas das aves e a necessidade de recuperação não inferior a 100\% em animais de vida livre, fazem da ortopedia nesta classe um desafio ímpar para os cirurgiões veterinários (REDIG, 1986; LEVITT, 1989; HELMER; REDIG, 2006). Howard e Redig ${ }^{1}$ (1993 apud PEREIRA, 2007, p. 259) exemplificam bem isto em relação às aves de rapina ao relatar que a porcentagem de animais em condição de soltura, após a reparação óssea, foi de $36 \%$ em casos de fraturas fechadas e de apenas $15 \%$ em fraturas abertas.

A escolha de uma técnica operatória apropriada para uma reparação ortopédica definitiva depende de diversas variáveis, tais como tamanho do paciente, grau de retorno à função pós-operatório vislumbrado, custo, habilidade do cirurgião, condição médica do paciente, comportamento natural e grau de atividade da ave,

\footnotetext{
${ }^{1}$ HOWARD, D. J.; REDIG, P. T. Analysis of avian fracture repairs: implication for captive and wild birds.

Proceedings Association of Avian Veterinarians Annual Conference. 1993. p. 78-82.
} 
requerimento funcional do membro afetado, tipo de injúria e osso envolvido (LEVITT, 1989; MARTIN; RITCHIE, 1994; BENNETT, 1997; HELMER; REDIG, 2006).

A meta de cada cirurgião deveria ser o retorno de cada paciente ao nível de atividade pré-injúria, porém isto nem sempre é possível. A técnica operatória mais adequada deve sempre ser indicada para os proprietários, porém alternativas de menor custo devem ser consideradas bem como a habilidade do cirurgião em realizá-las (HELMER; REDIG, 2006). Em pássaros de companhia, principalmente em psitacídeos - que usam o bico como instrumento para a sua locomoção - uma pequena perda da função do membro é aceitável, já nos pássaros de vida livre, é necessária a obtenção de um completo retorno à função (BENNETT, 1997; KAVANAGH, 1997).

Independente da técnica cirúrgica aplicada, a completa reabilitação da ave dependerá em grande parte dos cuidados pós-operatórios que podem incluir, por exemplo, um programa consistente de exercícios visando preparar fisicamente o animal às exigências impostas na natureza (WITHROW, 1982; MARTIN; RITCHIE, 1994; CHEBEZ; AGUILAR, 2001). Um aspecto importante em aves selecionadas para reabilitação é não arrancar as penas primárias e secundárias da asa durante a preparação pré-operatória, pois essas são imprescindíveis para o animal voar em vida livre e não serão repostas até a próxima muda, o que em algumas espécies pode levar anos (FOWLER, 2001).

Colares elisabetanos, quando necessários, são usados para prevenir a automutilação ou a destruição de implantes, bandagens ou talas: essa destruição é comum em psitacídeos (LEVITT, 1989).

Os acessos cirúrgicos aos ossos das aves estão descritos na literatura (BLASS, 1987; OROSZ; ENSLEY; HAYNES, 1992; MARTIN; RITCHIE, 1994). 


\subsubsection{Fraturas}

As fraturas podem ser classificadas com base em fatores causais, presença de comunicação externa, localização, morfologia e severidade da fratura, ou estabilidade da fratura em seguida a redução axial dos fragmentos, todas classificações úteis em descrevê-las (PIERMATTEI; FLO; DECAMP, 2006). Para aves não existe um sistema de classificação de fraturas que se assemelhe ao AO Vet para cães e gatos, adaptado do AO/ASIF humano, desenvolvido para permitir que as fraturas sejam codificadas de forma alfanumérica o qual permita graduar a complexidade da fratura e fornecer informações relacionadas a tratamento apropriado e prognóstico.

Redig (1986), ao revisar os dados referentes à reabilitação de rapinantes atendidos durante quatro anos, constatou que 34\% deles apresentaram uma ou mais fraturas de ossos longos. Ao avaliar problemas ortopédicos em 327 pombos atendidos durante 18 meses em um hospital veterinário da Inglaterra, McCartney (1994) observou que as fraturas representaram 70,3\% dos casos. No estudo de Santos et al. (2008) as fraturas representaram 30,91\% das afecções traumáticas, sendo a fratura rádio-ulnar a mais comum.

Segundo Blass (1987) as fraturas de asa são menos frequentes que as de perna, Bennett (1997), ao contrário, considera-as mais frequentes.

No estudo de Redig (1986), entre os rapinantes que foram operados, $77 \%$ apresentavam fraturas de membros torácicos e $23 \%$ de membros pélvicos. Em outro estudo retrospectivo de cinco anos em um centro que cuida de rapinantes na Carolina do Norte, ocorreram 239 fraturas de membro torácico, sendo a maioria em úmero e 62 fraturas de membro pélvico, a maioria em tibiotarso (SOUZA; FIELDS; DEGERNES, 2004).

Howard (1990) tratou cirurgicamente sete fraturas de asas e três de pernas de aves encaminhadas ao hospital veterinário da Universidade de Wisconsins de 1983 a 1986, e Kuzma e Hunter (1991) operaram dez fraturas em aves durante um período de dois anos no Canadá, das quais apenas uma foi de membro pélvico.

McCartney (1994) observou que as fraturas de asa superaram em duas vezes e meia as fraturas de perna nos pombos, sendo as fraturas de rádio e/ou ulna as mais frequentes. 
Arnaut (2006) encontrou 52,33\% de fraturas em membros pélvicos, sendo o osso mais acometido o tibiotarso (37,21\%) e 40,70\% de fraturas em membros torácicos, sendo o úmero $(18,60 \%)$ o mais acometido.

A maioria das fraturas da pelve e cinto peitoral (escápula, clavícula e coracóide) requer apenas tratamento conservativo com restrição de espaço (WITHROW, 1982; LEVITT, 1989; MARTIN; RITCHIE, 1994). Fraturas de coracóide com grande desvio em pássaros que necessitam de precisão no vôo devem ser reparadas cirurgicamente com fixação interna (WITHROW, 1982; REDIG, 1986; MARTIN; RITCHIE, 1994; COLES, 1996; BENNETT, 1997; HOLZ, 2003). Para as fraturas de rádio com a ulna intacta, carpometacarpos (COLES, 1996), tarsometatarsos e falanges a imobilização apenas com talas ou bandagens estão indicadas, assim como nos casos de fratura de tibiotarso sem grande desvio. Já para as fraturas de úmero e fêmur, o desvio freqüentemente moderado a severo dos fragmentos e a dificuldade de imobilização das articulações do ombro e coxofemoral, tornam o uso de talas inadequado, sendo indicado o tratamento cirúrgico (LEVITT, 1989).

Dentre as principais particularidades das aves destacam-se o fato de seus ossos apresentarem corticais finas e frágeis que resultam em menor fixação óssea de implantes; pouco tecido mole cobrindo os ossos, como resultado o suprimento sanguíneo e nervoso são mais comumente lesados; os segmentos fraturados são mais instáveis e perfuram a pele resultando em fragmentos ósseos não viáveis que formam seqüestros se incorporados à fixação; há pouco osso esponjoso disponível para enxertia; e, como são bipedais, o apoio deve ser restituído rapidamente na presença de afecção em membros pélvicos (HELMER; REDIG, 2006).

A importância do tamanho do paciente ainda é freqüentemente subestimada: técnicas cirúrgicas ortopédicas desenvolvidas para serem utilizadas em rapinantes, que pesam cerca de um quilo, são impossíveis de serem aplicadas a um canário de 20 gramas. A necessidade de redução do peso do implante, associado ao tamanho diminuto da ave, e o alto grau de morbidade e mortalidade cirúrgica, contribuem pela opção freqüente por tratamento conservativo das fraturas nestas aves pequenas (HELMER; REDIG, 2006). Harcourt-Brown (1996) comenta que a fixação com pinos é possível em araras, difícil em papagaios e virtualmente impossível em pequenos periquitos. Já para os rapinantes, todos os procedimentos ortopédicos propostos em aves já foram aplicados, e a fixação externa ou a combinação da fixação externa e 
interna parecem ser os métodos mais eficientes (CHEBEZ; AGUILAR, 2001; FOWLER, 2001).

Os princípios básicos e fundamentais da reparação ortopédica - alinhamento anatômico e funcional, fixação adequada, retorno precoce à função e baixa morbidade - e os princípios de redução e estabilização cirúrgica de fraturas, que consideram as forças compressivas, rotacionais, de flexão e de cisalhamento, assim como mínimo trauma aos tecidos moles, vascular e ósseo, são os mesmos para todas as classes de animais (REDIG, 1986; BLASS, 1987; LEVITT, 1989; MARTIN; RITCHIE, 1994; MACCOY, 1996; BENNETT, 1997; HELMER; REDIG, 2006).

Todas as técnicas ortopédicas desenvolvidas para uso em mamíferos têm aplicação na estabilização de fraturas em aves (BENNETT, 1997), entretanto suas corticais ósseas finas e frágeis tendem a fragmentar-se quando submetidas à força, não reagindo bem a métodos convencionais de fixação, motivo pelo qual raramente se justifica o uso de placas e parafusos nesta classe de animais (BLASS, 1987; LEVITT, 1989; KAVANAGH, 1997).

Para aves terrestres grandes, com corticais ósseas mais grossas, a osteossíntese com placas e parafusos estará indicada (BLASS, 1987; BENNETT, 1997), porém a desvantagem de necessitar de um tempo operatório maior se comparado a outras técnicas (BLASS, 1987; HOWARD, 1990; KAVANAGH, 1997) e de outro procedimento cirúrgico para a sua retirada (BLASS, 1987; KUZMA; HUNTER, 1991) devem ser considerados.

A fixação interna com pino intramedular (IM) é a técnica mais comum de reparação de fraturas na ortopedia de aves (LEVITT, 1989; SOUZA; FIELDS; DEGERNES, 2004). Simples e econômica, é empregada para a maioria das fraturas de úmero e fêmur (LEVITT, 1989). Alguns autores desestimulam o seu uso, ponderando que o pino IM apresenta diversas desvantagens quando comparado aos fixadores externos: potencial para causar injúria articular e periarticular, que resulta em anquilose; prejuízo ao tendão ou ligamento, promovendo a disfunção parcial do membro; e eficácia limitada sendo efetivo para estabilizar algumas fraturas em pássaros de companhia quando os proprietários não estão interessados no retorno ao vôo (MARTIN; RITCHIE, 1994).

Para que o pino IM não penetre às articulações adjacentes e interfira com a mobilidade articular, a sua colocação deve ser realizada de forma delicada e acurada pelo cirurgião. Apresenta como maior desvantagem a instabilidade 
rotacional, característica particularmente evidente quando utilizado no úmero, osso pneumático com canal medular largo e escasso osso esponjoso metafisário para a sua ancoragem. Para manter a estabilidade rotacional e de cisalhamento, enquanto o pino IM mantém o alinhamento axial e contêm as forças de flexão, indica-se em alguns casos o uso concomitante de cerclagens, hemicerclagens ou pinos externos transfixantes (GANDAL, 1982; WITHROW, 1982; LEVITT, 1989; MARTIN; RITCHIE, 1994; BENNETT, 1997; SOUZA; FIELDS; DEGERNES, 2004).

Hastes de polímero de alta densidade são alternativas à colocação de pinos IM na reparação de certas fraturas diafisárias de ossos longos e apresentam a vantagem de serem leves e de não necessitarem de procedimento cirúrgico adicional para a sua retirada (MACCOY, 1983; BLASS, 1987; LEVITT, 1989; MARTIN; RITCHIE, 1994).

O aparelho de Kirschner-Ehmer (K-E) e suas variações unipolares ou bipolares ("fixadores externos") apresentam resultados excelentes para fixação de diversas fraturas em aves, pois permitem o uso relativamente normal do membro acometido no período de convalescência e não lesam tecidos moles ou articulações que poderiam prejudicar a função dos membros, o que minimiza a atrofia por desuso e permite o rápido retorno à função. São estáveis contra todas as forças de fratura e ideais para fraturas expostas, cominutivas e/ou distais (LEVITT, 1989; MARTIN; RITCHIE, 1994; BENNETT, 1997). O uso do polimetilmetacrilato ao invés das barras de conexão de aço do fixador externo é especialmente apropriado para aves, pois permite maior variabilidade na escolha do tamanho do pino e reduz o peso do K-E (SATTERFIELD; O'ROURKE, 1981).

Alievi (2000), em experimento realizado com pombos-domésticos, no qual utilizou fixadores externos tipo I (unipolar) e II (bipolar) para reparar fraturas de tibiotarso, observou fixação rígida, pequena formação de calo ósseo e boa adaptação ao aparelho sem prejuízos funcionais, indicando-os para uso em aves de porte similar.

Souza, Fields e Degernes (2004) não encontraram diferenças nas taxas de sucesso obtidas com o uso de pinos IM e/ou cerclagens quando comparadas ao uso de fixadores externos em rapinantes com fraturas de membro torácico e pélvico.

Em aves faltam fontes autógenas doadoras de enxerto ósseo cortical e os aloenxertos e xenoenxertos são alternativas viáveis (BENNETT, 1997). Resultados similares quanto à consolidação, no uso de enxertos ósseos corticais xenógrafos 
derivados de avestruzes e de cães, comparados ao uso de fios de Kirschner na reparação de fraturas umerais em pombos, em estudo conduzido por Wander et al. (2000), demonstram tratar-se o enxerto xenógrafo em aves alternativa viável para a reparação de fraturas, com a vantagem de não necessitarem de remoção cirúrgica posterior. Estudo com pombos, conduzido por Bolson et al. (2008), no qual fraturas transversas de úmero foram induzidas e reparadas experimentalmente com pino IM de osso homólogo, as aves apresentaram retorno da função de vôo à normalidade.

O metilmetacrilato têm sido usado com resultados favoráveis sozinho (BORMAN; PUTNEY, 1978; BORMAN; PUTNEY; JESSUP, 1978; PUTNEY; BORMAN; LOHSE, 1983) ou associado a outras técnicas (KUZMA; HUNTER, 1991), para estabilização de fratura em aves. Na última década os conhecimentos sobre bio-polímeros evoluíram muito e materiais cimentantes como a poliuretana vegetal, derivada do polímero de mamona (Ricinnus communis), provou ser biocompatível, osteointegrável e considerado material opcional para cirurgia ortopédica nas aves (BOLSON et al., 2005).

A maioria das técnicas de fixação de fraturas aplica-se ao úmero, dentre as quais: pinos IM associados ou não à cerclagens, fixadores externos e placas (BENNETT, 1997). MacCoy (1992) considera o K-E tipo I e a fixação interna os métodos mais apropriados. Para fraturas muito distais um modelo de fixador externo transarticular tipo I pode ser apropriado (BENNETT, 1997). Na reparação das fraturas umerais qualquer grau de rotação pode resultar em deformidade da extremidade da asa e interferir com a habilidade em voar (WITHROW, 1982; LEVITT, 1989; MARTIN; RITCHIE, 1994; COLES, 2007). Os pinos IM foram o principal método de fixação cirúrgico utilizado no tratamento de fraturas umerais em rapinantes e não causaram danos às articulações, enquanto variações do aparelho de K-E falharam devido à perda prematura dos pinos transfixantes (REDIG, 1986). A reparação cirúrgica apenas com cerclagens de fratura exposta oblíqua distal de úmero em um pelicano foi efetiva, apesar de tratar-se de método de fixação secundário (KAVA; KAVA; KIBAR, 2001).

Nos casos de fratura de rádio ou da ulna com severa distração, nos quais pode ocorrer sinostose e conseqüente incapacidade de supinação e pronação, indica-se a fixação interna (BENNETT, 1997). Para os casos de fratura de ambos os ossos em pássaros que requerem precisão para voar, Coles (1996) indica a fixação 
interna ou externa da ulna (osso mais robusto que o rádio nas aves), enquanto Bennett (1997) afirma que o fixador externo é a técnica mais apropriada.

Os pinos IM, fixadores externos (MACCOY, 1992) e fios ortopédicos (MARTIN; RITCHIE, 1994; BENNETT, 1997) são recomendados para a reparação cirúrgica de fraturas em fêmur. Placas ósseas têm sido usadas com sucesso em fraturas fechadas (MARTIN; RITCHIE, 1994; BENNETT, 1997). Redig (1986) utilizou pinos IM para a reparação de fraturas de fêmur com resultados satisfatórios e assim como Blass (1987), considera-as de ocorrência pouco comum, provavelmente devido à musculatura da região que o protege.

Para as fraturas de tibiotarso, uma das afecções ortopédicas mais comuns em pássaros cativos (KAVANAGH, 1997), e as mais freqüentemente observadas em psitacídeos (HARCOURT-BROWN, 1996), Blass (1987) recomenda a reparação cirúrgica com pinos IM ou fixadores externos, em aves maiores que um papagaio; MacCoy (1992) e Martin e Ritchie (1994) consideram o fixador externo o método de eleição; Harcourt-Brown (1996) indica o pino IM que emerge cranialmente à articulação femorotibial com bons resultados quando associada à bandagem por 10 dias; e Bennett (1997) ressalta que têm obtido sucesso com os pinos IM, fios ortopédicos, placas ósseas e fixadores externos em aves grandes.

Redig (1986) operou 18 fraturas de tibiotarso em rapinantes, sendo que apenas seis consolidaram e quatro apresentaram retorno normal à função. Este autor refere que quatro de dez casos que receberam aparelho de K-E modificado foram reoperados com pinos IM sem sucesso. Fixador externo tipo II utilizado em uma arara com fratura de tibiotarso resultou em retorno total à função do membro (KAVANAGH, 1997).

A formação de calo ósseo exuberante ou de aderências que envolvam ligamentos e tendões adjacentes ao foco de fratura predispõem à ocorrência de restrições da mobilidade articular e conseqüente ausência do retorno à função, seqüela comum que pode ocorrer tanto diante da reparação cirúrgica como de uma imobilização prolongada (WITHROW, 1982; LEVITT, 1989). As aves são particularmente propensas a desenvolver a "doença da fratura" associada à imobilização do membro, caracterizada por anquilose articular, atrofia muscular e contratura tendínea (GANDAL, 1982; LEVITT, 1989; BENNETT, 1997).

A injúria aos tecidos moles, mais que a própria fratura, é freqüentemente a responsável pela recuperação lenta ou perda da função. A excessiva manipulação 
cirúrgica de tecidos moles e ósseos leva a um aumento da taxas de infecção, aderências e não-uniões avasculares (GANDAL, 1982; WITHROW, 1982; LEVITT, 1989; BENNETT, 1997). Apesar da injúria aos tecidos moles ocorrer em fraturas fechadas, o seu grau de severidade costuma ser maior nas fraturas expostas. Em rapinantes com fraturas fechadas o sucesso na reabilitação foi maior que nas fraturas expostas (HOWARD; REDIG ${ }^{2} 1993$ apud PEREIRA, 2007, p. 259; SOUZA; FIELDS; DEGERNES, 2004).

Apesar de pouco frequente, a osteomielite pode causar não-união pela esclerose das extremidades ósseas infectadas ou ser foco de infecção com formação de calo ao seu redor, com possibilidade de afetar sistemicamente a ave (WITHROW, 1982; BLASS, 1987; MARTIN; RITCHIE, 1994; SOUZA; FIELDS; DEGERNES, 2004).

Nos casos de fraturas onde houve severo dano vascular, aos tecidos moles e/ou aos nervos com conseqüente gangrena e/ou perda de função, a amputação do membro estará indicada (GANDAL, 1982). O resultado da amputação da asa é usualmente cosmético e as aves ficam bem, enquanto a amputação da perna pode predispor a ocorrência de afecções nos pés da perna remanescente (WITHROW, 1982).

\subsubsection{Luxações}

As luxações não são reportadas com freqüência nas aves (MARTIN; RITCHIE, 1994). Em pombos, as luxações de ombro e de cotovelo representaram apenas $5,3 \%$ das afecções ortopédicas das asas (MCCARTNEY, 1994). Estudo retrospectivo que abordou fraturas e luxações de membros torácicos e pélvicos em rapinantes mostrou a ocorrência de apenas 4,7\% de luxações (SOUZA; FIELDS; DEGERNES, 2004). No estudo radiográfico de Arnaut (2006), as luxações representaram 25,53\% das afecções traumáticas, sendo a luxação do joelho

\footnotetext{
${ }^{2}$ HOWARD, D. J.; REDIG, P. T. Analysis of avian fracture repairs: implication for captive and wild birds. Proceedings Association of Avian Veterinarians Annual Conference. 1993. p. 78-82.
} 
$(46,15 \%)$ a mais freqüente. Santos et al. (2008) encontrou 9,1\% de luxações dentre as afecções traumáticas em aves.

As luxações de joelho são raras em pássaros de companhia (ROSENTHAL; HILLYER; MATHIESSEN, 1994; BENNETT, 1997), as luxações de ombro e cotovelo são igualmente incomuns, mas ocorrem em rapinantes (MARTIN; RITCHIE, 1994; SOUZA; FIELDS; DEGERNES, 2004) e as luxações coxofemorais ocorrem ocasionalmente em pássaros de companhia e psitacídeos (MARTIN; RITCHIE, 1994; QUESENBERRY; OROSZ; DORRESTEIN, 1997), todas associadas a episódios traumáticos. Luxações congênitas podem ocorrer em periquitos (BLASS, 1987).

Há poucos relatos de métodos para o tratamento de luxações em aves. A reparação cirúrgica dos ligamentos do joelho pode ser realizada em aves grandes, já nas pequenas, o tamanho dos ligamentos exclui esta possibilidade (BENNETT, 1997). Para a estabilização cirúrgica do joelho após a redução da luxação, indica-se um fixador externo transarticular - a articulação deve ser mantida em posição anatômica por tempo suficiente para permitir sua reparação pela fibrose antes que a rigidez se torne definitiva (BLASS, 1987; BENNETT, 1997) - ou ainda técnicas de artrodese que promovam sua fusão definitiva (QUESENBERRY; OROSZ; DORRESTEIN, 1997). Os fixadores externos são implantes provisórios que permitem à ave utilizar o membro no período de convalescença com rápido retorno à função. A artrodese é alternativa à amputação do membro e indicada para os casos de injuria irreparável (ROSENTHAL; HILLYER; MATHIESSEN, 1994).

Rosenthal, Hillyer e Mathiessen (1994) utilizaram fixador externo tipo I para reparação de luxação de joelho em uma cacatua e em uma suindara, respectivamente para promover artrodese e fibrose periarticular, e consideraram o fixador efetivo para este tipo de afecção em aves. Alievi et al. (2001) também utilizou fixador externo transarticular em luxação de joelho de um papagaio, como método para artrodese, diante da impossibilidade de redução via artrotomia. Chinnadurai et al. (2009) publicaram recentemente o uso de uma técnica extracapsular de estabilização para reparar a luxação de joelho em um papagaio-do-congo (Psittacus erithacus) associada à transposição cranial da fíbula em um calau-trombeteiro (Bycanistes bucinator), ambos apresentaram retorno à função do membro após um mês da operação. 


\subsubsection{Avulsão traumática de extremidade}

O traumatismo aos dígitos está entre as injúrias mais comumente vistas na clínica de aves. Nos casos mais graves, nos quais a viabilidade do tecido é questionável e ocorre evolução para gangrena, a amputação é necessária (QUESENBERRY; OROSZ; DORRESTEIN, 1997).

\subsubsection{Artrite e osteomielite}

Muitas bactérias têm sido associadas à sinovite e artrite em aves, e a origem da infecção atribuída a feridas por trauma ou a via hematógena. Geralmente as aves desenvolvem edema uni ou bilateral das articulações, sendo a tibiotarsotarsometatársica a mais comumente acometida nos psitacídeos e a úmero-rádioulnar nos pombos. O tratamento envolve lavagem da articulação, através ou não de artrotomia, e antibioticoterapia baseada em cultura e antibiograma (CATB) (QUESENBERRY; OROSZ; DORRESTEIN, 1997).

Arnaut (2006) em seu estudo radiográfico encontrou sete casos de artrite (7/201), ocorridos em Psittaciformes, Passeriformes e Columbiformes, todos acometendo a articulação intertársica.

Infecções graves com envolvimento ósseo podem ser irresponsivas à antibioticoterapia. Quesenberry et al. (1997) obtiveram sucesso em alguns casos com a artrodese em psitacídeos, para interrupção da progressão da infecção e alívio da dor.

No estudo de McCartney (1994) a artrite séptica correspondeu a 2,6\% das afecções ortopédicas das asas em pombos, e apesar do tratamento com antibióticos, o retorno à função de vôo não foi alcançado. 


\subsection{AFECÇÕES CIRÚRGICAS DE TECIDOS MOLES DAS AVES}

As operações em tecidos moles realizadas em aves apresentaram um aumento substancial na última década, atribuído ao uso difundido da anestesia com isofluorano, introdução de técnicas de microcirurgia para as aves, radiocirurgia bipolar e a especialização crescente dos cirurgiões de aves. Contudo, limitações para cirurgias do abdômen em espécies muito pequenas (<100 gramas) ou para cirurgias torácicas, mesmo em espécies grandes, cujo acesso é dificultado pela cobertura do esterno e musculatura avantajada, são difíceis de superar (BENNETT; HARRISON, 1994).

Forbes (2002), na introdução do seu artigo de revisão sobre cirurgia do trato digestório em aves, escreve "qualquer aspirante a cirurgião de aves deve primeiro tornar-se um competente cirurgião de pequenos animais. A manipulação adequada dos tecidos moles é mandatória para o seu sucesso".

\subsubsection{Neoplasias}

Uma grande variedade de doenças neoplásicas é vista em aves de estimação (SCHMIDT; QUESENBERRY, 1997). Com o crescimento do conhecimento e melhora da qualidade da clínica de aves, as doenças neoplásicas vêm se tornando mais que um diagnóstico posmortem, contudo, as informações publicadas ainda encontram-se limitadas (REAVILL, 2004) particularmente quanto ao seu tratamento (LIGHTFOOT, 2006).

Blackmore (1966) afirma que casos de neoplasias são observados com maior freqüência em Psittaciformes e Galliformes, porém raramente vistos em Columbiformes e Anseriformes, enquanto Reece (1992) em pesquisa realizada em laboratório de diagnóstico australiano que incluiu aves comerciais, de zoológicos, de criadouros, de vida-livre e de companhia encontrou 3,9\% de incidência de tumores, sendo destas 58\% em Psittaciformes - 40\% em periquito-australiano (Melopsittacus 
undulatus) - seguida de Passeriformes (14\%), Columbiformes (12\%) e Anseriformes (7\%).

A prevalência de neoplasias diagnosticadas em 22 ordens de aves foi de 5,8\%, este estudo foi realizado de 1994 a 2002 por serviço americano especializado. Os resultados mostraram que a pele foi o sítio de maior ocorrência tumoral; as ordens Anseriformes (11,6\%), Strigiformes (9,9\%) e Galliformes (9,4\%) apresentaram as maiores taxas de prevalência tumoral; e os tipos tumorais mais comuns foram os carcinomas cutâneos de células escamosas, linfoma multicêntrico e sarcoma cutâneo de tecidos moles. Quanto à ordem Psittaciformes, que apresentou 6,2\% de taxa de prevalência tumoral, a calopsita (Nymphicus hollandicus) (17,7\%), seguida do papagaio (Amazona sp.) $(13,6 \%)$ e da arara (Ara sp.) $(12,7 \%)$ foram as espécies mais acometidas, e o sarcoma de tecidos moles foi a neoplasia mais observada (10,5\%) (GARNER, 2006).

Sinhorini (2008) em estudo analisou a freqüência e prevalência com que ocorrem os processos neoplásicos em aves; encontrou a ordem Psittaciformes, como a maior em número de casos, o periquito-australiano como a ave com maior prevalência tumoral seguido do gênero Amazona. O lipoma foi a neoplasia de maior ocorrência e a pele e subcutâneo a localização mais freqüente. No levantamento das doenças que acometeram as aves, Santos et al. (2008) observou 4,91\% de ocorrência de neoplasias, das quais 73,68\% não identificadas e 26,32\% lipomas.

$\mathrm{Na}$ literatura nacional encontram-se relatos de neoplasias em psitacídeos envolvendo um único paciente, como o de um rabdomiossarcoma na região cervical de um papagaio-verdadeiro (ARAÚJO et al., 2007), um carcinoma cutâneo de células basais em região umeral de um periquito-australiano (FREITAS et al., 2008) e um tumor maligno de bainha nervosa na face de um papagaio-verdadeiro (SARMENTO; SANCHES; PACHALY, 2008).

O câncer em pássaros é comumente tratado com a excisão cirúrgica da massa neoplásica, se sua localização assim o permitir, ou com a amputação de membros acometidos, na impossibilidade de sua ressecção. A terapia da neoplasia em qualquer animal freqüentemente requer a combinação de tratamentos para conseguir sucesso e o uso de quimioterapia e radioterapia no tratamento de neoplasias em pássaros é ainda inexplorado (SCHMIDT; QUESENBERRY, 1997; COLES, 2007). A crioterapia pode ser usada para tumores pequenos localizados ao 
redor da cavidade oral e narinas ou como complemento para a excisão de tumores de base ampla (FILIPPICH, 2004).

Latimer (1994) cita o lipoma e o fibrossarcoma como os tumores mais freqüentes que acometem o sistema tegumentar das aves, enquanto Gandal (1982) inclui também os carcinomas.

Os lipomas que ocorrem normalmente no subcutâneo costumam ser bem vascularizados (LATIMER, 1994; ALTMAN, 1997b) e de ocorrência mais freqüente no esterno, região abdominal e parte interna das coxas (FILIPPICH, 2004). A excisão cirúrgica é indicada se estiver causando problemas clínicos que não foram resolvidos com a mudança na dieta e aumento dos exercícios (LATIMER, 1994; LIGHTFOOT, 2006). É comum sua recidiva se removido de forma incompleta (REAVILL, 2004). Vistos em todas as espécies, são mais freqüentes em periquitos (SCHMIDT; QUESENBERRY, 1997; LIGHTFOOT, 2006), cacatuas, papagaios do gênero Amazona e calopsitas (REAVILL, 2004).

Os lipossarcomas podem apresentar-se como múltiplos nódulos localmente agressivos, porém raramente são encontrados nas aves (SCHMIDT; QUESENBERRY, 1997; REAVILL, 2004).

O carcinoma de células escamosas é um tumor epitelial maligno que tende a se desenvolver em locais de inflamação crônica (REAVILL, 2004), localmente agressivo com tendência a recidiva, apesar das metástases serem raras (REAVILL, 2004; LIGHTFOOT, 2006). Reavill (2004) cita como sítios primários de ocorrência nas aves a pele e o trato digestório superior (bico, cavidade oral, esôfago, inglúvio e proventrículo); Lightfoot (2006) cita as junções mucocutâneas da cabeça, porção distal de asas e falanges. Mais comumente observado em calopsitas, papagaios e periquitos domésticos (REAVILL, 2004). O tratamento consiste em excisão cirúrgica (FILIPPICH, 2004; REAVILL, 2004) ou radioterapia (REAVILL, 2004).

A neoplasia linfóide em aves de vida livre ou de cativeiro não tem sido estudada em detalhes e não apresenta tratamento efetivo (LATIMER, 1994). Schmidt e Quesenberry (1997) afirmam que o linfossarcoma pode ser encontrado na pele, subcutâneo e órgãos diversos.

Os hemagiossarcomas são descritos em aves como localmente invasivos, com recidiva após dias ou meses da sua excisão cirúrgica. As calopsitas são as aves mais freqüentemente diagnosticadas com este tipo de neoplasia, seguida de galinhas, cisnes, papagaios, agapornes, periquitos domésticos e alguns 
passeriformes (REAVILL, 2004). Quanto às localizações mais comuns, alguns autores citam pele, subcutâneo e ossos (SCHMIDT; QUESENBERRY, 1997) e outros citam bico, asas, pés, pernas e cloaca (REAVILL, 2004).

Melanomas vêm sendo diagnosticados em vários psitacídeos (SCHMIDT; LIGHTFOOT, 2006), sendo o bico e a face os locais mais comuns de sua ocorrência (SCHMIDT; QUESENBERRY, 1997; REAVILL, 2004). Reavill (2004) descreveu dois casos de melanoma na região cefálica de papagaios-do-congo (Psittacus erithacus), um no bico de um periquito-australiano e também algumas lesões na pele, asa e disseminados pelo corpo em cacatuas, sendo que todos apresentaram recidiva após tratamento cirúrgico. Stern e Lamm (2009) relataram a ocorrência de melanoma no subcutâneo do ombro de uma cacatua (Cacatua alba) que veio a óbito após a exérese do tumor.

\subsubsection{Neoformações cutâneas ou de anexos não neoplásicas}

A presença de massas não neoplásicas de aspecto variado deve ser diferenciada das neoplasias, através de exames citológicos, cultura e/ou biópsias. Lesões granulomatosas e cáseos podem ser o resultado da penetração de corpo estranho, bactérias, fungos ou reações a injeções (BAUCK; OROSZ; DORRESTEIN, 1997; SCHMIDT; QUESENBERRY, 1997).

Particularmente em papagaios, cáseos ou abscessos na cavidade oral podem localizar-se na língua ou em coanas comprometendo também cavidade nasal, e devem ser abertos e curetados cirurgicamente (COLES, 2007).

Os cistos infundibulares ("cistos de pena") envolvem um ou mais folículos de penas, contêm material grumoso denso e penas não desenvolvidas. Localizam-se mais freqüentemente nas asas e dorso do corpo. Ocorrem em diversas espécies, mas são mais comuns em canários (GANDAL, 1982; QUESENBERRY; OROSZ; DORRESTEIN, 1997). Coles (2007) afirma jamais ter observado esta afecção em aves silvestres. A excisão com o uso de bisturi comum é preferível ao uso do bisturi elétrico, que pode lesionar os folículos adjacentes, transformando-os também em cistos (CUBAS; GODOY, 2007). 
O termo xantoma significa "massa amarela". Não é considerado por muitos autores como neoplasia verdadeira, mas uma intumescência inflamatória resultante do acúmulo de macrófagos com lipídeos em seu interior, células gigantes, colesterol livre e diversos graus de fibrose (LATIMER, 1994; BOWLES et al., 2006). Localizamse mais comumente na porção distal de asa (BOWLES et al., 2006), área de púbis, esterno e quilha (LIGHTFOOT, 2006; SCHMIDT; LIGHTFOOT, 2006). Reportados mais freqüentemente em psitacídeos e galináceos (REAVILL, 2004), são considerados muito comuns em periquito-australiano e calopsitas (COLES, 1996; REAVILL, 2004; SCHMIDT; LIGHTFOOT, 2006). O tratamento de escolha é a excisão cirúrgica (REAVILL, 2004), sendo necessária em alguns casos a amputação do membro acometido (BOWLES et al., 2006).

Nas aves, lesões granulomatosas causadas pelo Mycobacterium sp., agente etiológico da tuberculose, podem ocorrer em diversos órgãos como fígado, baço, pulmão, trato gastrointestinal, rim, ossos e articulações, sendo a carpometacárpica e a do cotovelo as articulações mais comumente atingidas, com possibilidade de apresentar a pele sobre elas fina e ulcerada. A formação de tubérculos na pele é rara, mas pode estar presente como nódulos de diversos tamanhos, repleto de material fibrinoso amarelado (GERLACH, 1994; POLLOCK, 2006). O diagnóstico baseia-se nos achados de necrópsia, pesquisa de bacilos nas fezes e em lesões em órgãos fixados e corados com corante Ziehl-Neelsen, porém o diagnóstico conclusivo é dado pela cultura bacteriana e técnicas de biologia molecular (GUIMARÃES, 2007). A tuberculose em psitacídeos é predominantemente causada pelo M. tuberculosis e representa um clássico exemplo de antropozoonose ou zoonose reversa, isto é, a infecção de um animal a partir de um ser humano infectado; a via de infecção mais comum é a respiratória. Mais raramente os psitacídeos podem apresentar tuberculose por M. avium (CATÃO-DIAS; CARVALHO, 2007). 


\subsection{3 "Necrose avascular de dígito"}

A síndrome de constricção do dígito é vista em psitacídeos e caracteriza-se por uma banda anular de tecido ao redor de um ou mais dígitos que causam edema e gangrena da porção distal à constricção. Sua etiologia é desconhecida (QUESENBERRY; OROSZ; DORRESTEIN, 1997), sendo atribuída em alguns casos à constricção mecânica por penas ou fios que se enrolam aos dígitos causando inchaço e gangrena (HARCOURT-BROWN, 1996).

$\mathrm{Na}$ dependência do caso, o tratamento consiste da remoção cirúrgica do material causador da constricção, da excisão circunferencial da região de constricção com anastomose da pele ou da amputação do dígito a partir da articulação proximal à área afetada, sendo a incisão cutânea distal à articulação para provimento de tecido suficiente para a sutura sem tensão (BENNETT; HARRISON, 1994; BOWLES et al., 2006).

\subsubsection{Ferida na região da quilha}

Ocorre mais em pássaros de vida livre que colidem com objetos e a pele se divide sobre o esterno. Pode ocorrer também em pássaros de companhia, após colisão ou queda (ALTMAN, 1997b), particularmente em espécies com corpo mais pesado, como os papagaios, ao tentar voar (BOWLES et al., 2006).

O impacto causa a laceração e gangrena da pele diretamente sobre a quilha. Contaminação e exposição do tecido subcutâneo e periósteo dificultam a cicatrização das bordas da ferida. Curetagem do periósteo e incisões paralelas a ferida original para reduzir a tensão podem ser necessárias (ALTMAN, 1997b). Feridas muito extensas podem necessitar de cicatrização por segunda intenção (BOWLES et al., 2006).

Psitacídeos com lesões ulceradas no esterno causadas por automutilação apresentaram cicatrização favorável, quando submetidos a debridamento cirúrgico 
do tecido necrótico, associada a imobilização das asas para prevenir o vôo (HOCHLEITHNER; HOCHLEITHNER, 1996).

\subsubsection{Gangrena de extremidade de membros}

Feridas traumáticas de dígitos estão entre as injúrias mais comuns vistas na prática da clínica aviária. Podem ser causadas por brigas com outras aves, esmagamento por portas de gaiola ou mobiliário, constricções do metatarso resultado de traumatismos envolvendo anilhas e, em pequenos psitacídeos e passeriformes, é comum a constricção ocorrer ao redor dos pés e dígitos por cordas ou material de nidificação. Caracterizam-se por edema e extensa lesão aos tecidos moles, associadas ou não a fraturas, sendo necessária a amputação do membro, nos casos nos quais não há resposta favorável ao tratamento medicamentoso, (QUESENBERRY; OROSZ; DORRESTEIN, 1997).

\subsubsection{Hérnia abdominal}

As hérnias abdominais em aves não são hérnias verdadeiras devido à inexistência de abertura ou anel na aponeurose dos músculos abdominais, portanto aprisionamento e estrangulamento de vísceras não ocorrem (ALTMAN, 1997b).

É mais freqüente entre as fêmeas, resultado da pressão na musculatura abdominal quando da postura de ovos, se observada em machos deve-se pesquisar a alteração de vísceras da cavidade celomática (GANDAL, 1982). Forbes (2002) refere que é encontrada com maior freqüência em fêmeas obesas de psitacídeos, principalmente de cacatuas e periquitos. Langlois e Jones (2001) relatam a ocorrência de hérnia abdominal associada a hepatomegalia por lipidose hepática, em uma fêmea obesa da espécie papagaio-escarlate (Eos bornea), submetida com 
sucesso à celiotomia para biópsia hepática e reparação da hérnia pela linha média ventral.

Gandal (1982) indica a reparação cirúrgica com técnicas similares àquelas utilizadas para os mamíferos, enquanto Altman (1997b) indica a cirurgia corretiva abdominoplastia - para a remoção de parte da parede abdominal distendida, após certificar-se que não existam aderências da parede às alças intestinais, garantindo que lacerações iatrogênicas de vísceras não ocorram.

\subsubsection{Perfuração de cavidade celomática}

Pássaros com injúrias decorrentes de feridas por mordedura são usualmente apresentados com histórico de trauma conhecido, resultado do ataque por cães, gatos ou pássaros maiores. Após a estabilização inicial do paciente, a lavagem copiosa com solução salina estéril, debridamento com excisão de tecido desvitalizado, bandagens e antibioticoterapia bactericida de amplo espectro podem ser necessários (QUESENBERRY; OROSZ; DORRESTEIN, 1997).

\subsubsection{Neoformação em cavidade celomática}

Não é infreqüente a necessidade de explorar a cavidade celomática para estabelecer o diagnóstico definitivo de aves com aumento abdominal generalizado (GANDAL, 1982). Forbes (1996) cita as formações neoplásicas ou de outra origem em cavidade celomática, como uma das várias doenças que podem apresentar-se com sinais de dispnéia em psitacídeos.

Tumores do sistema geniturinário constituem a maioria dos tumores abdominais, são usualmente malignos e a maioria dos pacientes com tais tumores são apresentados em estágio avançado. A combinação de um tumor extremamente grande com aderências e um pequeno espaço de trabalho torna o procedimento 
cirúrgico praticamente impossível (GANDAL, 1982; FILIPPICH, 2004). Segundo Altman (1997b), tumores intrabadominais são difíceis de remover, a operação requer magnificação e usualmente resulta em óbito.

\subsubsection{Distocia (retenção de ovo)}

A distocia é problema comum, particularmente em patos e psitacídeos, e têm sido associada a malformações dos ovos, incluindo grandeza, casca mole, superfície áspera ou forma irregular. Atonia uterina, nutrição inadequada, predisposição genética, tumores do trato reprodutivo ou sua compressão por massas abdominais também contribuem para a retenção de ovo (BENNETT; HARRISON, 1994). Santos et al. (2008) encontraram 0,85\% de ocorrência de distocia dentre as doenças de aves atendidas.

A ovocentese pode ser realizada pela cloaca ou através da parede abdominal (COLES, 2007). Para realizar a ovocentese, uma agulha calibrosa deve ser introduzida dentro do ovo, o conteúdo aspirado e aplicada gentil compressão para que o ovo colapse dentro do oviducto; uma vez colapsado utiliza-se pinça que prenda a casca para então o ovo ser extraído. Duas condições decorrentes da ruptura de oviducto - gema livre ou ovos inteiros livres na cavidade celomática - têm prognóstico reservado e ambas necessitam de lavagem e drenagem da cavidade (GANDAL, 1982). Altman (1997b) indica a celiotomia para os casos nos quais o ovo não possa ser visualizado pela cloaca.

Se for necessária a histerotomia para a remoção do ovo, recomenda-se referendar o oviducto com uma ou duas suturas prévias à sua incisão, visto que suas paredes se contraem após a abertura tornando-se finas, o que dificulta a síntese (COLES, 2007). 


\subsubsection{Fístula de papo}

Dos vários segmentos do trato digestório das aves o inglúvio ou papo, como é comumente designado, é aquele que mais requer intervenção cirúrgica, e esta deve ser realizada com extremo cuidado, principalmente na manipulação da parede, que é fina e se rompe facilmente (GANDAL, 1982).

Feridas penetrantes causadas por mordedura de animais, técnica para alimentação assistida inadequada, ingestão de corpos estranhos, trauma ou consumo de alimentação excessivamente quente podem resultar na formação de uma fístula que requer tratamento cirúrgico (BENNETT; HARRISON, 1994). Segundo Rupley (1999), a reparação de fístulas por queimadura e as biópsias são cirurgias ingluviais comuns.

A fístula de papo, resultante da queimadura térmica causada pela administração de alimento superaquecido acomete principalmente neonatos e filhotes jovens afastados dos pais, devido à necessidade de serem alimentados manualmente pelo homem. Sinais clínicos ocorrem tipicamente dez dias após o incidente, quando a crosta da ferida pela queimadura diminui e um trajeto fistuloso pelo qual vaza alimento é observado (SIMPSON, 1996; GREENACRE, 2003).

A técnica consiste da remoção do tecido desvitalizado com separação da pele e papo - o que pode ser um desafio se áreas extensas estiveram lesionadas - e síntese do papo em padrão invertido e da pele separadamente (HALL, 1996; SIMPSON, 1996; FORBES, 2002).

\subsubsection{Perfuração de esôfago}

Lacerações causadas pelo tubo de alimentação ou mordeduras podem traumatizar o esôfago das aves (FORBES, 2002). Altman (1997b) indica a reparação cirúrgica imediata se diagnosticada a perfuração pela sonda durante a alimentação, ou, no caso de um diagnóstico tardio, quando já existe uma severa resposta inflamatória, a limpeza e debridamento do tecido comprometido e colocação de uma 
sonda alimentar proventricular de espera por cinco a sete dias, para então realizarse a reparação cirúrgica.

\subsubsection{Corpo estranho em trato gastrointestinal}

A retirada de corpos estranhos (CE) do papo deve ser realizada preferivelmente por endoscopia via cavidade oral, desde que indicado para o caso (ALTMAN, 1997b).

Corpos estranhos que saem do papo podem se alojar em qualquer parte do sistema digestório (GANDAL, 1982).

A cirurgia intestinal é pouco realizada em aves, enquanto a ingluviotomia para remoção de CE ou para via de acesso ao esôfago caudal e proventrículo para a realização de endoscopia, é cirurgia comum (RUPLEY, 1999; CUBAS; GODOY, 2007; FORBES, 2002).

A proventriculotomia é a mais indicada para a remoção de CE do proventrículo e ventrículo, que não possam ser retirados por endoscopia via ingluviotomia. Os autores preferem a proventriculotomia através do istmo para acessar o ventrículo e remover o conteúdo com instrumentação, evitando assim uma ventriculotomia (BENNETT; HARRISON, 1994; FORBES, 2002; BOWLES et al., 2006).

\subsubsection{Prolapso de cloaca}

Psitacídeos do Velho Mundo como cacatuas são os mais acometidos por esta afecção (BENNETT; HARRISON, 1994; ALTMAN, 1997b; FORBES, 2002; BOWLES et al., 2006), cuja etiologia é desconhecida e atribuída a um déficit neuromuscular da parede da cloaca com redução do tônus do esfíncter (BENNETT; HARRISON, 1994; ALTMAN, 1997b; BOWLES et al., 2006). É fundamental diferenciá-lo da hipertrofia ou do papiloma (ALTMAN, 1997b), pois prolapsos e papilomas freqüentemente requerem intervenção cirúrgica (RUPLEY, 1999). 
A sutura em bolsa-de-fumo poderá ser ineficaz para os prolapsos totais que ocluem ureteres e cólon, assim como para os prolapsos recorrentes, nos quais a cloacopexia poderá estar indicada (BENNETT; HARRISON, 1994; COLES, 2007). Bowles et al. (2006) e Coles (2007) recomendam a cloacopexia cuidadosa com duas suturas percutâneas em cada lado do abdômen ventral. A cloacopexia com confecção de suturas ao redor das duas últimas costelas causou o encarceramento do cólon entre a cloaca e a parede abdominal nos dois psitacídeos operados (RADLINSKY et al., 2004).

\subsubsection{Sinusite}

Altman (1997b) afirma que um dos problemas respiratórios mais comuns encontrado em aves, particularmente nos psitacídeos, é a infecção dos seios causada por bactérias, fungos ou leveduras, que usualmente evoluem para infecção crônica com distensão dos seios por exsudato caseoso, podendo causar também necrose tecidual. Segundo este autor, o isolamento do agente infeccioso é essencial para o sucesso do tratamento, além da lavagem e drenagem cirúrgicas. Forbes (1996) e Bowles et al. (2006) recomendam a trepanação dos seios cuidadosamente para não provocar hemorragia, como último recurso para os casos nos quais a lavagem com antibióticos não obteve sucesso.

\subsubsection{Otite}

A abertura do ouvido externo é oculta por penas e a pele ao seu redor é solta. Ausência de penas ou penas unidas por descarga seropurulenta e aumento de volume de tecido ao redor do canal de abertura do ouvido são sinais de otite (KERN, 1997). Apesar de pouco freqüente é a afecção de ouvido mais citada na literatura, e 
pode necessitar de curetagem para auxílio no tratamento médico (ALTMAN, 1997b; KERN, 1997).

\subsection{AFECÇÕES CIRÚRGICAS SEGUNDO A TAXONOMIA}

De acordo com o tipo de ave, ou seja, o gênero, a família e a ordem a qual pertence, determinadas afecções com indicação para tratamento cirúrgico podem ocorrer em maior ou menor freqüência ou não ocorrer, como, por exemplo, para o caso das afecções relacionadas ao inglúvio que poderão ser observadas em psitaciformes, galiformes e columbiformes, que possuem esta estrutura proeminente e jamais vistas em espécies como o tucano, a coruja, a gaivota, o pingüim, o pato e o ganso que não o possuem (HOEFER; OROSZ; DORRESTEIN, 1997; RUPLEY, 1999).

Injúrias traumáticas estão entre as afecções mais encontradas pelos veterinários cirurgiões que trabalham com psitacídeos (SIMPSON, 1996). Apesar de tumores subcutâneos serem vistos em todas as espécies de aves, são mais comuns em psitacídeos, particularmente em periquitos-australianos (COLES, 2007). Godoy (2007) afirma que algumas das intervenções cirúrgicas mais freqüentes nestas aves são: a reparação de ferimentos cutâneos, a redução de fraturas, a remoção de CE, o reparo de queimaduras ingluviais e a remoção de cáseos ou coleções líquidas decorrentes das sinusites. A amputação de membros indicada para alguns casos de traumas extensos, neoplasias, não-união de fraturas ou infecções, é bem tolerada pelos psitacídeos (BOWLES et al., 2006).

As cirurgias mais freqüentes realizadas em anseriformes são as de contenção de vôo, resolução de fraturas e escoriações, intervenções corretivas na ranfoteca e resolução cirúrgica para "bumblefoot"3 (GRESPAN, 2007).

Forbes (2002) refere que é comum pombas serem atendidas com extensas injúrias de papo, após chocarem-se com fios de arames, e indica a remoção de tecidos desvitalizados e a reparação cirúrgica, mesmo diante de uma grande perda da parede do órgão, que é bem tolerado por esta espécie. Os columbídeos

\footnotetext{
${ }^{3}$ Termo em inglês usual na clínica de aves, traduzido como pododermatite. Caracteriza-se por um inchaço da almofada do metatarso, freqüentemente associado à infecção das falanges proximais.
} 
apresentam um plexo vascular na fáscia subcutânea ao redor do esôfago e na lateral do pescoço. Caso haja ampla lesão nesta região a hemorragia pode ser fatal (VOGEL; GERLACH; LÖFFLER, 1994).

Para os ranfastídeos (tucanos e araçaris) a reparação de fraturas de bico é intervenção clínico-cirúrgica comum e fraturas ósseas são tratadas com as mesmas técnicas cirúrgicas empregadas em psitacídeos e aves de rapina (CUBAS, 2007). O trauma à articulação tarsometatarsal é freqüente, em sua maioria relacionado ao transporte destes pássaros, e resultam em severa redução da mobilidade articular, com graus variados de anquilose, proliferação óssea, severa osteomielite e edema de tecidos moles, sendo indicado a artrotomia para limpeza e colheita de material para CATB. O tratamento de casos avançados costuma ser insatisfatório (WORELL, 1997).

Para os rapinantes diurnos (Falconiformes) e noturnos (Strigiformes) de vida livre, os autores citam os traumatismos como indiscutivelmente a principal causa para a realização de tratamentos cirúrgicos, bem como a principal causa de mortalidade neste grupo de aves (JOHNSON-DELANEY, 1996; CHEBEZ; AGUILAR, 2001; FOWLER, 2001). Neste contexto, a reparação de fraturas em ossos longos nas aves de rapina merece destaque entre as intervenções cirúrgicas em função não apenas de sua elevada incidência, como também de sua grande variabilidade de resultados. Outra afecção freqüente em rapinantes, embora mais observado em cativeiro, e que pode necessitar de intervenção cirúrgica em casos avançados é o "bumblefoot"4 (FORBES, 2000). A endoscopia é empregada como técnica de sexagem, exame complementar e também como método para remoção de colônias de Aspergillus spp ou de nematódeos instalados em sacos aéreos e que podem acusar obstrução respiratória. Operações oculares para o tratamento de catarata são igualmente relatadas em aves de rapina (PEREIRA, 2007).

\footnotetext{
${ }^{4}$ Termo em inglês usual na clínica de aves, traduzido como pododermatite. Caracteriza-se por um inchaço da almofada do metatarso, freqüentemente associado à infecção das falanges proximais.
} 
MATERIAL E MÉTODO 



\section{MATERIAL E MÉTODO}

Foram analisados os prontuários das aves submetidas a intervenções cirúrgicas no Serviço de Cirurgia de Pequenos Animais do HOVET-FMVZ/USP, no período compreendido entre janeiro de 2000 a junho de 2008. Para a seleção dos prontuários realizou-se pesquisa nos arquivos de registro de casos do referido serviço.

Os prontuários pertencem ao HOVET-FMVZ/USP e possuem número de registro único para cada paciente. Cada prontuário contém os dados de resenha do animal e as informações para identificação do proprietário e, quando realizados, as fichas de atendimento e tratamento dos diferentes serviços, os resultados de exames e os relatórios cirúrgicos.

Os dados referentes aos exames necroscópicos e histopatológicos (HP) foram obtidos através de pesquisa nos arquivos do Serviço de Patologia Animal do HOVET-FMVZ/USP, englobando o mesmo período.

Os procedimentos cirúrgicos para correção de afecções de bico e oftalmológicas não foram incluídos neste estudo, pois o atendimento destas afecções ocorre em outros serviços.

Procedimentos cirúrgicos para contenção de vôo e prevenção de fugas, tais como amputação de metacarpianos ou tendonectomia e técnicas de laparoscopia para sexagem não são realizadas pelo Serviço de Cirurgia de Pequenos Animais do HOVET-FMVZ/USP, portanto não foram abordados.

Este estudo foi aprovado pela Comissão de Bioética da FMVZ/USP, protocolo no 1494/2008 em 02 de outubro de 2008.

\subsection{LEVANTAMENTO RETROSPECTIVO}

Os prontuários foram analisados individualmente para colheita de informações de interesse para a realização deste estudo. Inicialmente tais informações foram compiladas em fichas previamente elaboradas e divididas em duas categorias 
segundo o tipo de afecção cirúrgica: Ortopedia (APÊNDICE A) e Tecidos Moles (APÊNDICE B). O nome do proprietário e telefone de contato foram anotados nas respectivas fichas, os quais permitiram, em alguns casos, a complementação dos dados de interesse inexistentes nos prontuários.

\subsection{ARMAZENAMENTO DOS DADOS}

Todas as informações constantes nas fichas foram transcritas para um programa de computação desenvolvido para este estudo, associado a um Sistema Gerenciador de Banco de Dados Relacional (SGBDR).

A nomenclatura científica e a ordem taxonômica das espécies de aves ocorrentes em território brasileiro seguiram o Comitê Brasileiro de Registros Ornitológicos (CBRO, 2009) e das espécies de ocorrência internacional o Avibase (AVIBASE, 2009). As espécies ameaçadas de extinção estão de acordo com a Lista das Espécies da Fauna Brasileira Ameaçadas de Extinção do Ministério do Meio Ambiente (BRASIL, 2003a; b). Para os nomes comuns foram reconhecidos os mais usuais no local em estudo.

\subsection{SELEÇÃO DOS DADOS}

Após revisão dos dados obtidos e armazenados no SGBDR, foram selecionadas as informações pertinentes aos objetivos deste estudo: tipo de afecção cirúrgica, espécies acometidas, e para cada um dos grupos - Ortopedia e Tecidos Moles - aquelas de maior relevância clínico-cirúrgica, relacionadas a seguir. 


\subsubsection{Ortopedia}

Para este grupo foram considerados os dados referentes ao tipo de afecção, membro e osso e/ou articulação acometidos, tipo de técnica operatória, avaliação radiográfica (consolidação, eixo ósseo) e retorno à função pós-operatório. Quanto às fraturas, optamos por adotar um sistema de classificação modificado de Matera (1975), no qual se considerou a presença de comunicação com o meio exterior e o número de linhas de fratura e de fragmentos ósseos (Quadro 2).

Quanto a presença de comunicação externa

Fechada: sem comunicação com meio exterior, pele íntegra

Exposta: sítio da fratura comunicou-se com meio exterior, presença de ferida aberta ou cicatrizada

Quanto ao número de linhas de fratura e de fragmentos ósseos

Simples: uma linha de fratura, dois fragmentos ósseos

Dupla: duas linhas de fratura, três fragmentos ósseos

Cominutiva: superior a duas linhas de fratura

Fonte: Adaptado de MATERA, E. A. Traumatismos. In: Belo Horizonte: Cooperativa Veterinária de Consumo Ltda., 1975.

Lições de patologia cirúrgica geral.

Quadro 2 - Classificação de fraturas em aves

\subsubsection{Tecidos Moles}

Para este grupo foram considerados tipo de afecção e sua localização, tipo de técnica operatória, pós-operatório imediato, recidiva e seguimento. 


\subsection{DOCUMENTAÇÃO FOTOGRÁFICA}

Foram selecionadas fotografias de pacientes no pré, trans e/ou pós-operatório e imagens radiográficas, com o objetivo de ilustrar as diversas etapas do trabalho envolvido no tratamento cirúrgico de cada paciente.

\subsection{ANÁLISE DOS RESULTADOS}

Realizou-se a análise dos resultados por meio de consultas ao SGBDR e foram expressos mediante a distribuição numérica $(N)$ e percentual (\%) e apresentados sob a forma de tabelas e gráficos.

A maior parte dos resultados observados neste estudo foi separada em dois grupos - Ortopedia e Tecidos Moles - a fim de facilitar a compreensão e ordenar os dados compilados.

Para a avaliação dos resultados obtidos com as técnicas operatórias empregadas para o grupo Ortopedia utilizou-se os seguintes critérios de exclusão: falta de dados referentes à técnica cirúrgica utilizada, ausência de seguimento registrado nos respectivos prontuários e impossibilidade de sua complementação por contato telefônico com os proprietários ou casos cuja técnica operatória realizada foi a amputação de membro ou somente a colheita de material para diagnóstico.

Para a avaliação dos resultados obtidos com as técnicas operatórias empregadas para o grupo Tecidos Moles o critério de exclusão foi exclusivamente a falta de dados referentes ao pós-operatório imediato registrado nos respectivos prontuários e impossibilidade de sua complementação por contato telefônico com os proprietários. 
RESULTADOS 



\section{RESULTADOS}

\subsection{NÚMERO DE OPERAÇÕES}

O número de intervenções cirúrgicas realizadas em aves no Serviço de Cirurgia de Pequenos Animais do HOVET-FMVZ/USP, no período compreendido entre janeiro de 2000 a junho de 2008, totalizou 90 operações, das quais $\mathbf{3 0 \%}$ (27/90) foram para diagnóstico e/ou tratamento de afecções ortopédicas e 70\% $(63 / 90)$ para diagnóstico e/ou tratamento de afecções de tecidos moles.

\subsection{NÚMERO DE ANIMAIS E CLASSIFICAÇÃO TAXONÔMICA}

Em relação ao número de animais, foram operadas 87 aves no Serviço de Cirurgia de Pequenos Animais do HOVET-FMVZ/USP, no período compreendido entre janeiro de 2000 a junho de 2008, pertencentes a seis diferentes ordens: Psittaciformes 89,66\% (78/87), Anseriformes 2,30\% (2/87), Columbiformes 2,30\% (2/87), Piciformes 2,30\% (2/87), Passeriformes 2,30\% (2/87) e Falconiformes 1,15\% $(1 / 87)$.

Do total de aves operadas pertencente a seis diferentes ordens e sete diferentes famílias, 25,29\% (22/87) foi identificado apenas quanto ao gênero enquanto 74,71\% (65/87) quanto à espécie, dentre as quais três delas, representadas cada uma por um indivíduo, constam da Lista das Espécies da Fauna Brasileira Ameaçadas de Extinção do Ministério do Meio Ambiente (BRASIL, 2003a; b). O "grupo dos papagaios", para o qual foram considerados todos os exemplares pertencentes aos gêneros Amazona e Deroptyus, foi prevalente e representou $67,82 \%$ (59/87) das aves operadas. Estes dados estão apresentados na tabela 1. 
Tabela 1 - Distribuição numérica (N) e percentual (\%) das 87 aves operadas segundo a taxonomia (AVIBASE, 2009; CBRO, 2009) - São Paulo janeiro de 2000 a junho de 2008

\begin{tabular}{|c|c|c|c|c|c|}
\hline Ordem & Família & Nome Científico & Nome Comum & $\mathbf{N}$ & $\%$ \\
\hline \multirow{15}{*}{ PSITTACIFORMES } & \multirow{15}{*}{ PSITTACIDAE } & \# Amazona aestiva & $\begin{array}{l}\text { Papagaio- } \\
\text { verdadeiro }\end{array}$ & 30 & 34,48 \\
\hline & & \# Amazona amazonica & Curica, papagaio & 7 & 8,05 \\
\hline & & $\begin{array}{l}\text { \# Amazona } \\
\text { brasiliensis* }\end{array}$ & $\begin{array}{l}\text { Papagaio-de-cara- } \\
\text { roxa }\end{array}$ & 1 & 1,15 \\
\hline & & $\begin{array}{l}\text { \# Amazona } \\
\text { ochrocephala }\end{array}$ & $\begin{array}{l}\text { Papagaio- } \\
\text { campeiro }\end{array}$ & 1 & 1,15 \\
\hline & & \# Amazona sp. & Papagaio & 18 & 20,69 \\
\hline & & \# Amazona vinacea* & $\begin{array}{l}\text { Papagaio-de- } \\
\text { peito-roxo }\end{array}$ & 1 & 1,15 \\
\hline & & $\begin{array}{l}\text { Anodorhynchus } \\
\text { hyacinthinus* }\end{array}$ & Arara-azul-grande & 1 & 1,15 \\
\hline & & Ara ararauna & Arara-canindé & 5 & 5,75 \\
\hline & & Ara macao & Arara-vermelha & 1 & 1,15 \\
\hline & & Brotogeris sp. & Periquito-verde & 3 & 3,45 \\
\hline & & $\begin{array}{l}\text { \# Deroptyus } \\
\text { accipitrinus }\end{array}$ & Anacã & 1 & 1,15 \\
\hline & & Diopsittaca nobilis & $\begin{array}{l}\text { Maracanã- } \\
\text { pequena }\end{array}$ & 1 & 1,15 \\
\hline & & Melopsittacus undulatus & $\begin{array}{l}\text { Periquito- } \\
\text { australiano }\end{array}$ & 4 & 4,60 \\
\hline & & Platycercus eximius & Rosela & 1 & 1,15 \\
\hline & & Nymphicus hollandicus & Calopsita & 3 & 3,45 \\
\hline \multirow[b]{2}{*}{ ANSERIFORMES } & \multirow[b]{2}{*}{ ANATIDAE } & Cairina moschata & Pato-doméstico & 1 & 1,15 \\
\hline & & Cygnus sp. & Cisne & 1 & 1,15 \\
\hline COLUMBIFORMES & COLUMBIDAE & Columba livia & Pombo-doméstico & 2 & 2,30 \\
\hline PICIFORMES & RAMPHASTIDAE & Ramphastos toco & Tucano-toco & 2 & 2,30 \\
\hline PASSERIFORMES & FRINGILLIDAE & Serinus canaria & Canário-do-reino & 2 & 2,30 \\
\hline FALCONIFORMES & FALCONIDAE & Caracara plancus & Carcará & 1 & 1,15 \\
\hline Total & & & & 87 & 100,00 \\
\hline
\end{tabular}

\# espécies que compõem o "grupo dos papagaios"

* espécies da Fauna Brasileira ameaçadas de extinção

O número total de aves operadas foi 87 enquanto o total de operações foi 90 , pois duas aves foram submetidas a mais de uma intervenção cirúrgica ao longo do período de estudo: uma foi operada duas e a outra três vezes. 


\subsection{DISTRIBUIÇÃO DAS OPERAÇÕES SEGUNDO AS ORDENS}

Em relação ao número de operações ortopédicas realizadas (27/90) segundo as diferentes ordens de aves nas quais ocorreram, observou-se: Psittaciformes 85,19\% (23/27), Piciformes 7,41\% (2/27), Anseriformes 3,70\% (1/27) e Falconiformes 3,70\% (1/27). Para as operações de tecidos moles (63/90) os psitaciformes representaram 92,06\% (58/63), columbiformes 3,17\% (2/63), passeriformes 3,17\% (2/63) e anseriformes 1,59\% (1/63). A distribuição percentual das intervenções cirúrgicas realizadas para os dois grupos - Ortopedia e Tecidos Moles - segundo as ordens as quais pertencem as espécies operadas encontra-se no gráfico 1.

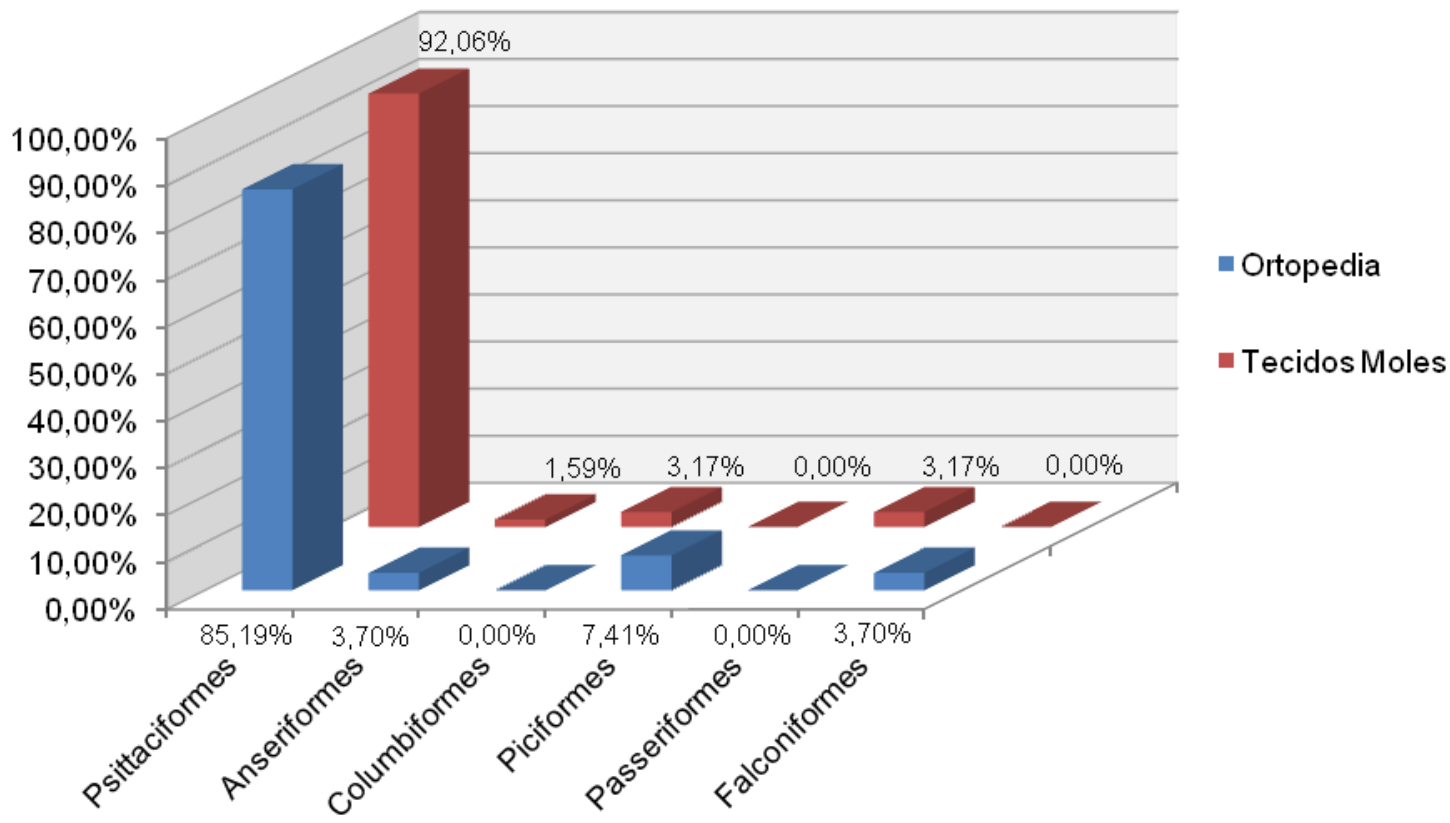

Gráfico 1 - Distribuição percentual do total de operações em aves segundo as ordens - São Paulo - janeiro de 2000 a junho de 2008 


\subsection{ORTOPEDIA}

A análise dos dados referentes às 27 operações para diagnóstico e/ou tratamento de afecções ortopédicas permitiu identificar as seguintes afecções ósseas e/ou articulares:

- fratura

- luxação

- avulsão traumática de extremidade

- artrite e osteomielite

A tabela 2 demonstra os diferentes tipos de afecções ortopédicas das aves submetidas a diagnóstico e/ou tratamento cirúrgico, os membros acometidos e sua ocorrência.

Tabela 2 - Distribuição numérica $(\mathrm{N})$ e percentual (\%) quanto ao tipo e membro acometido do total de afecções cirúrgicas ortopédicas das aves operadas - São Paulo - janeiro de 2000 a junho de 2008

\begin{tabular}{lcccccc}
\hline \multirow{2}{*}{ Afecção ortopédica } & \multicolumn{2}{c}{ Membro torácico } & \multicolumn{2}{c}{ Membro pélvico } & \multicolumn{2}{c}{ Total } \\
\cline { 2 - 7 } & $\mathbf{N}$ & $\mathbf{\%}$ & $\mathbf{N}$ & $\mathbf{\%}$ & $\mathbf{N}$ & $\mathbf{\%}$ \\
\hline \hline Fratura & 8 & 29,63 & 16 & 59,26 & 24 & 88,89 \\
Luxação & 0 & 0,00 & 1 & 3,70 & 1 & 3,70 \\
Avulsão traumática de extremidade & 0 & 0,00 & 1 & 3,70 & 1 & 3,70 \\
Artrite e osteomielite & 0 & 0,00 & 1 & 3,70 & 1 & 3,70 \\
\hline \hline \multicolumn{1}{c}{ Total } & $\mathbf{8}$ & $\mathbf{2 9 , 6 3}$ & $\mathbf{1 9}$ & $\mathbf{7 0 , 3 7}$ & $\mathbf{2 7}$ & $\mathbf{1 0 0 , 0 0}$ \\
\hline \hline
\end{tabular}


Nas tabelas 3 e 4 encontram-se discriminados os dados referentes às 24 fraturas operadas, segundo classificação modificada de Matera (1975), adotada para este estudo.

Tabela 3 - Distribuição numérica (N) e percentual (\%) quanto ao membro acometido e presença de comunicação externa das 24 fraturas das aves operadas São Paulo - janeiro de 2000 a junho de 2008

\begin{tabular}{lcccccc}
\hline \multirow{2}{*}{ Fratura } & \multicolumn{2}{c}{ Membro torácico } & \multicolumn{2}{c}{ Membro pélvico } & \multicolumn{2}{c}{ Total } \\
\cline { 2 - 7 } & $\mathbf{N}$ & $\mathbf{\%}$ & $\mathbf{N}$ & $\mathbf{\%}$ & $\mathbf{N}$ & $\%$ \\
\hline \hline Fechada & 3 & 12,50 & 13 & 54,17 & 16 & 66,67 \\
Exposta & 5 & 20,83 & 2 & 8,33 & 7 & 29,17 \\
Não relatado & 0 & 0,00 & 1 & 4,17 & 1 & 4,17 \\
\hline \hline \multicolumn{1}{c}{ Total } & $\mathbf{8}$ & $\mathbf{3 3 , 3 3}$ & $\mathbf{1 6}$ & $\mathbf{6 6 , 6 7}$ & $\mathbf{2 4}$ & $\mathbf{1 0 0 , 0 0}$ \\
\hline \hline
\end{tabular}

Tabela 4 - Distribuição numérica $(\mathrm{N})$ e percentual (\%) quanto ao membro acometido e número de linhas de fratura das 24 fraturas das aves operadas - São Paulo - janeiro de 2000 a junho de 2008

\begin{tabular}{lcccccc}
\hline \multirow{2}{*}{ Fratura } & \multicolumn{2}{c}{ Membro torácico } & \multicolumn{2}{c}{ Membro pélvico } & \multicolumn{2}{c}{ Total } \\
\cline { 2 - 7 } & $\mathbf{N}$ & $\mathbf{\%}$ & $\mathbf{N}$ & $\mathbf{\%}$ & $\mathbf{N}$ & $\mathbf{\%}$ \\
\hline \hline Simples & 4 & 16,67 & 12 & 50,00 & 16 & 66,67 \\
Dupla & 1 & 4,17 & 1 & 4,17 & 2 & 8,33 \\
Cominutiva & 1 & 4,17 & 1 & 4,17 & 2 & 8,33 \\
Não relatado & 2 & 8,33 & 2 & 8,33 & 4 & 16,67 \\
\hline \hline \multicolumn{1}{c}{ Total } & $\mathbf{8}$ & $\mathbf{3 3 , 3 3}$ & $\mathbf{1 6}$ & $\mathbf{6 6 , 6 7}$ & $\mathbf{2 4}$ & $\mathbf{1 0 0 , 0 0}$ \\
\hline \hline
\end{tabular}


A distribuição das afecções cirúrgicas ortopédicas com a descrição completa obtida e os ossos ou articulações nos quais ocorreram estão apresentadas na tabela 5.

Tabela 5 - Distribuição numérica $(\mathrm{N})$ e percentual (\%) do total de afecções cirúrgicas ortopédicas das aves operadas segundo o osso elou articulação acometidos e descrição obtida - São Paulo - janeiro de 2000 a junho de 2008

\begin{tabular}{|c|c|c|c|}
\hline Ossos elou articulações acometidos & Descrição da afecção ortopédica & $\mathbf{N}$ & $\%$ \\
\hline \multirow{5}{*}{ Úmero } & Fratura fechada simples & 3 & 11,11 \\
\hline & Fratura exposta & 2 & 7,41 \\
\hline & Fratura exposta simples & 1 & 3,70 \\
\hline & Fratura exposta dupla & 1 & 3,70 \\
\hline & Total & 7 & 25,93 \\
\hline \multirow[t]{2}{*}{ Rádio-ulna e metacarpos } & Fratura exposta cominutiva $\S$ & 1 & 3,70 \\
\hline & Fratura fechada simples & 3 & 11,11 \\
\hline \multirow[t]{4}{*}{ Fêmur } & Fratura fechada dupla & 1 & 3,70 \\
\hline & Total & 4 & 14,81 \\
\hline & Fratura & 1 & 3,70 \\
\hline & Fratura fechada simples & 8 & 29,63 \\
\hline \multirow{4}{*}{ Tibiotarso } & Fratura fechada cominutiva $\S$ & 1 & 3,70 \\
\hline & Fratura exposta & 1 & 3,70 \\
\hline & Fratura exposta simples & 1 & 3,70 \\
\hline & Total & 12 & 44,44 \\
\hline Articulação femorotibiotársica & Luxação fechada joelho & 1 & 3,70 \\
\hline Tarsometatarso & Avulsão traumática de extremidade § & 1 & 3,70 \\
\hline Articulação intertársica & Artrite e osteomielite & 1 & 3,70 \\
\hline \multicolumn{2}{|l|}{ Total } & 27 & 100,00 \\
\hline
\end{tabular}

$\S$ associada à osteomielite 
A ocorrência dos diferentes tipos de afecções cirúrgicas ortopédicas segundo as ordens as quais pertencem as espécies operadas encontra-se na tabela 6 a seguir:

Tabela 6 - Distribuição numérica $(\mathrm{N})$ e percentual (\%) do total de afecções cirúrgicas ortopédicas de aves operadas segundo as ordens - São Paulo - janeiro de 2000 a junho de 2008

\begin{tabular}{|c|c|c|c|c|c|c|c|c|c|c|}
\hline \multirow{2}{*}{ Afecção ortopédica } & \multicolumn{2}{|c|}{ Psittaciformes } & \multicolumn{2}{|c|}{ Anseriformes } & \multicolumn{2}{|c|}{ Piciformes } & \multicolumn{2}{|c|}{ Falconiformes } & \multicolumn{2}{|c|}{ Total } \\
\hline & $\mathbf{N}$ & $\%$ & $\mathbf{N}$ & $\%$ & $\mathbf{N}$ & $\%$ & $\mathbf{N}$ & $\%$ & $\mathbf{N}$ & $\%$ \\
\hline Fratura & 21 & 77,78 & 1 & 3,70 & 1 & 3,70 & 1 & 3,70 & 24 & 88,89 \\
\hline Luxação & 1 & 3,70 & 0 & 0,00 & 0 & 0,00 & 0 & 0,00 & 1 & 3,70 \\
\hline $\begin{array}{l}\text { Avulsão traumática } \\
\text { de extremidade }\end{array}$ & 1 & 3,70 & 0 & 0,00 & 0 & 0,00 & 0 & 0,00 & 1 & 3,70 \\
\hline Artrite e osteomielite & 0 & 0,00 & 0 & 0,00 & 1 & 3,70 & 0 & 0,00 & 1 & 3,70 \\
\hline Total & 23 & 85,19 & 1 & 3,70 & 2 & 7,41 & 1 & 3,70 & 27 & 100,00 \\
\hline
\end{tabular}

Quanto à distribuição dos tipos de afecções cirúrgicas ortopédicas segundo as espécies acometidas, observou-se apenas um caso de fratura ocorrido em um cisne (Cygnus sp.) da ordem Anseriformes que representou 3,7\% (1/27), um caso de fratura e outro de artrite e osteomielite em dois tucanos-toco (Ramphastos toco) da ordem Piciformes que representaram 7,41\% (2/27), e um caso de fratura em um carcará (Caracara plancus) da ordem Falconiformes que representou 3,7\% (1/27), sendo que $85,19 \%$ (23/27) dos casos restantes ocorreram em espécies pertencentes à ordem Psittaciformes e encontram-se na tabela 7, na qual se observa o "grupo dos papagaios", para o qual se considerou todos os exemplares pertencentes ao gênero Amazona, como prevalente representando 55,55\% (15/27) dos casos e 65,22\% (15/23) das espécies de psitaciformes. 
Tabela 7 - Distribuição numérica $(\mathrm{N})$ e percentual (\%) quanto ao tipo das 23 afecções cirúrgicas ortopédicas operadas em psitaciformes segundo as espécies São Paulo - janeiro de 2000 a junho de 2008

\begin{tabular}{|c|c|c|c|c|c|c|c|c|}
\hline \multirow{2}{*}{$\begin{array}{c}\text { Nome comum } \\
\text { (Nome científico) }\end{array}$} & \multicolumn{2}{|c|}{ Fratura } & \multicolumn{2}{|c|}{ Luxação } & \multicolumn{2}{|c|}{$\begin{array}{l}\text { Avulsão } \\
\text { traumática }\end{array}$} & \multicolumn{2}{|c|}{ Total } \\
\hline & $\mathbf{N}$ & $\%$ & $\mathbf{N}$ & $\%$ & $\mathbf{N}$ & $\%$ & $\mathbf{N}$ & $\%$ \\
\hline $\begin{array}{l}\text { \# Papagaio-verdadeiro } \\
\text { (Amazona aestiva) }\end{array}$ & 4 & 17,39 & 0 & 0,00 & 0 & 0,00 & 4 & 17,39 \\
\hline $\begin{array}{l}\text { \# Curica, papagaio } \\
\text { (Amazona amazonica) }\end{array}$ & 1 & 4,35 & 1 & 4,35 & 0 & 0,00 & 2 & 8,70 \\
\hline $\begin{array}{l}\text { \# Papagaio-de-peito-roxo } \\
(\text { Amazona vinacea*) }\end{array}$ & 1 & 4,35 & 0 & 0,00 & 0 & 0,00 & 1 & 4,35 \\
\hline $\begin{array}{l}\text { \# Papagaio } \\
\text { (Amazona sp.) }\end{array}$ & 8 & 34,78 & 0 & 0,00 & 0 & 0,00 & 8 & 34,78 \\
\hline $\begin{array}{l}\text { Arara-azul-grande } \\
\text { (Anodorhynchus hyacinthinus*) }\end{array}$ & 1 & 4,35 & 0 & 0,00 & 0 & 0,00 & 1 & 4,35 \\
\hline $\begin{array}{l}\text { Arara-canindé } \\
\text { (Ara ararauna) }\end{array}$ & 2 & 8,70 & 0 & 0,00 & 0 & 0,00 & 2 & 8,70 \\
\hline $\begin{array}{l}\text { Periquito-verde } \\
\text { (Brotogeris sp.) }\end{array}$ & 2 & 8,70 & 0 & 0,00 & 0 & 0,00 & 2 & 8,70 \\
\hline $\begin{array}{l}\text { Periquito-australiano } \\
\text { (Melopsittacus undulatus) }\end{array}$ & 0 & 0,00 & 0 & 0,00 & 1 & 4,35 & 1 & 4,35 \\
\hline $\begin{array}{l}\text { Calopsita } \\
\text { (Nymphicus hollandicus) }\end{array}$ & 2 & 8,70 & 0 & 0,00 & 0 & 0,00 & 2 & 8,70 \\
\hline Total & 21 & 91,30 & 1 & 4,35 & 1 & 4,35 & 23 & 100,00 \\
\hline
\end{tabular}

\# espécies pertencentes ao gênero Amazona que compõem o "grupo dos papagaios"

* espécies da Fauna Brasileira ameaçadas de extinção

O número de técnicas operatórias realizadas neste estudo para diagnóstico e/ou tratamento das afecções cirúrgicas ortopédicas totalizou 28 , representadas por 53,57\% (15/28) de fixação interna, 21,43\% (6/28) de amputação, 14,29\% (4/28) de fixação externa, 3,57\% (1/28) de ostectomia + tala, 3,57\% (1/28) de colheita de material (HP e CATB) e 3,57\% (1/28) não informada no prontuário. O número de técnicas operatórias foi 28 enquanto o de afecções ortopédicas foi 27, pois para uma das afecções utilizou-se a associação de duas técnicas - fixação interna + externa. Os dados relacionados aos tipos de técnicas operatórias e sua ocorrência estão na tabela 8, a seguir: 
Tabela 8 - Distribuição numérica $(\mathrm{N})$ e percentual (\%) quanto ao tipo de técnica operatória utilizada nas aves operadas segundo as afecções ortopédicas - São Paulo - janeiro de 2000 a junho de 2008

\begin{tabular}{|c|c|c|c|c|c|c|c|c|c|c|c|c|c|c|c|c|c|c|c|c|}
\hline \multirow{4}{*}{$\begin{array}{c}\text { Afecção } \\
\text { ortopédica }\end{array}$} & \multicolumn{18}{|c|}{ Técnica operatória } & \multirow{3}{*}{\multicolumn{2}{|c|}{ Total }} \\
\hline & \multicolumn{8}{|c|}{ Fixação interna } & \multirow{2}{*}{\multicolumn{2}{|c|}{$\begin{array}{c}\begin{array}{c}\text { Fixação } \\
\text { externa }\end{array} \\
\text { Transfixador }\end{array}$}} & \multirow{2}{*}{\multicolumn{2}{|c|}{ Amputação }} & \multirow{2}{*}{\multicolumn{2}{|c|}{$\begin{array}{l}\text { Ostectomia } \\
+ \text { tala }\end{array}$}} & \multirow{2}{*}{\multicolumn{2}{|c|}{$\begin{array}{c}\text { Colheita de } \\
\text { material } \\
\text { (HP, } \\
\text { CATB) }\end{array}$}} & \multirow{2}{*}{\multicolumn{2}{|c|}{$\begin{array}{l}\text { Não } \\
\text { relatada }\end{array}$}} & & \\
\hline & \multicolumn{2}{|c|}{ PIM } & \multicolumn{2}{|c|}{$\begin{array}{c}\mathrm{PIM}+ \\
\mathrm{Ce}\end{array}$} & \multicolumn{2}{|c|}{ EOH } & \multicolumn{2}{|c|}{$\begin{array}{c}\mathrm{P}+\mathrm{Ce}+ \\
\mathrm{HCe}\end{array}$} & & & & & & & & & & & & \\
\hline & $\mathbf{N}$ & $\%$ & $\mathbf{N}$ & $\%$ & $\mathbf{N}$ & $\%$ & $\mathbf{N}$ & $\%$ & $\mathbf{N}$ & $\%$ & $\mathbf{N}$ & $\%$ & $\mathbf{N}$ & $\%$ & $\mathbf{N}$ & $\%$ & $\mathbf{N}$ & $\%$ & $\mathbf{N}$ & $\%$ \\
\hline Fratura & 11 & 39,29 & 2 & 7,14 & 1 & 3,57 & 1 & 3,57 & 3 & 10,71 & 5 & 17,86 & 1 & 3,57 & 0 & 0,00 & 1 & 3,57 & 25 & 89,29 \\
\hline Luxação & 0 & 0,00 & 0 & 0,00 & 0 & 0,00 & 0 & 0,00 & 1 & 3,57 & 0 & 0,00 & 0 & 0,00 & 0 & 0,00 & 0 & 0,00 & 1 & 3,57 \\
\hline $\begin{array}{l}\text { Avulsão traumática } \\
\text { de extremidade }\end{array}$ & 0 & 0,00 & 0 & 0,00 & 0 & 0,00 & 0 & 0,00 & 0 & 0,00 & 1 & 3,57 & 0 & 0,00 & 0 & 0,00 & 0 & 0,00 & 1 & 3,57 \\
\hline $\begin{array}{l}\text { Artrite e } \\
\text { osteomielite }\end{array}$ & 0 & 0,00 & 0 & 0,00 & 0 & 0,00 & 0 & 0,00 & 0 & 0,00 & 0 & 0,00 & 0 & 0,00 & 1 & 3,57 & 0 & 0,00 & 1 & 3,57 \\
\hline Total & 11 & 39,29 & 2 & 7,14 & 1 & 3,57 & 1 & 3,57 & 4 & 14,29 & 6 & 21,43 & 1 & 3,57 & 1 & 3,57 & 1 & 3,57 & 28 & 100,00 \\
\hline
\end{tabular}

HP (histopatológico); CATB (cultura e antibiograma); PIM - pino intramedular; Ce - cerclagem; EOH - enxerto ósseo heterólogo; P - polímero; HCe hemicerclagem 
Para avaliação dos resultados obtidos com as técnicas operatórias empregadas para o tratamento das afecções ortopédicas foram excluídos 11 casos (APÊNDICE C), dos quais quatro devido à falta de dados clínico-cirúrgicos (técnica operatória) e/ou de seguimento (retorno à função) registrados nos respectivos prontuários e impossibilidade de sua complementação por contato telefônico com os proprietários, seis por se tratarem de amputações, cuja técnica operatória "per se" é nula quanto ao retorno à função do membro operado e um por tratar-se de quadro sistêmico de artrite e osteomielite bacteriana cuja intervenção cirúrgica foi exclusivamente a colheita de material para estabelecer o diagnóstico definitivo.

Os 16 casos avaliados e respectivos resultados obtidos com as técnicas operatórias empregadas para tratamento das afecções ortopédicas encontram-se na tabela 9 e imagens de etapas do diagnóstico e/ou tratamento cirúrgico nas figuras 15.

Segundo análise dos resultados obtidos no tratamento cirúrgico das 15 fraturas, a fixação interna com pino intramedular empregada em 11 casos (73,33\%, 11/15), sendo que em um deles a cerclagem com fio de aço esteve associada, apresentou quanto à avaliação radiográfica em relação à consolidação $72,72 \%$ (8/11) de calo ósseo, 18,18\% (2/11) de reação periostal e 9,09\% (1/11) de ausência de informação; quanto à avaliação radiográfica em relação ao eixo ósseo 81,81\% (9/11) excelente, 9,09\% (1/11) ruim e 9,09\% (1/11) ausência de informação e quanto ao retorno à função 90,90\% (10/11) total e 9,09\% (1/11) parcial. A fixação externa com transfixador empregada em dois casos $(13,33 \%, 2 / 15)$, um na configuração bipolar e outro unipolar associado à fixação interna com polímero, cerclagem e hemicerclagem, apresentou quanto à avaliação radiográfica em relação à consolidação 100\% (2/2) de calo ósseo; quanto à avaliação radiográfica em relação ao eixo ósseo 50\% (1/2) excelente e 50\% (1/2) satisfatório e 100\% (2/2) de total retorno à função. A fixação interna com enxerto heterólogo empregada em um caso $(6,66 \%, 1 / 15)$ apresentou quanto à avaliação radiográfica em relação à consolidação 100\% (1/1) de reação periostal; quanto à avaliação radiográfica em relação ao eixo ósseo 100\% (1/1) satisfatório e 100\% (1/1) de total retorno à função. A ostectomia associada à tala, empregada em um caso $(6,66 \%, 1 / 15)$, apresentou ausência de informação quanto à avaliação radiográfica em relação à consolidação e ao eixo ósseo e 100\% (1/1) de total retorno à função. 
A artrotomia para redução e a estabilização com transfixador unipolar foi a técnica operatória empregada para o único caso de luxação fechada de joelho e apresentou quanto à avaliação radiográfica em relação ao eixo ósseo $100 \%$ (1/1) excelente e 100\% (1/1) de total retorno à função. A ausência de informação quanto à avaliação radiográfica em relação à consolidação deve-se à natureza da afecção e tipo de técnica empregada. 
Tabela 9 - Distribuição dos 16 casos avaliados quanto aos resultados obtidos com as técnicas operatórias para afecções ortopédicas utilizadas nas aves - São Paulo - janeiro de 2000 a junho de 2008

\begin{tabular}{|c|c|c|c|c|c|c|c|c|c|c|c|c|c|c|c|c|}
\hline \multirow{3}{*}{$\begin{array}{c}N^{\circ} \\
\text { do } \\
\text { caso }\end{array}$} & \multirow{3}{*}{ Nome comum (Nome científico) } & \multirow{3}{*}{$\begin{array}{l}\text { Afecção ortopédica } \\
\text { (descrição completa) }\end{array}$} & \multirow{3}{*}{ Técnica operatória } & \multicolumn{8}{|c|}{ Avaliação radiográfica } & \multirow{2}{*}{\multicolumn{5}{|c|}{ Retorno à função }} \\
\hline & & & & \multicolumn{4}{|c|}{ Consolidação } & \multicolumn{4}{|c|}{ Eixo ósseo } & & & & & \\
\hline & & & & SI & 0 & 1 & 2 & SI & 0 & 1 & 2 & SI & 0 & 1 & 2 & 3 \\
\hline 1 & Papagaio-verdadeiro (Amazona aestiva) & Fratura fechada simples tibiotarso $\mathrm{E}$ & $\mathrm{FI}-\mathrm{PIM}$ & & & & $x$ & & & & $x$ & & & & $x$ & \\
\hline 4 & Calopsita (Nymphicus hollandicus) & Fratura exposta úmero $\mathrm{E}$ (antiga) & Ostectomia + tala & $\mathrm{x}$ & & & & $x$ & & & & & & & $\mathrm{x}$ & \\
\hline 8 & Papagaio-verdadeiro (Amazona aestiva) & Fratura fechada simples úmero $\mathrm{E}$ & FI - PIM & & & $x$ & & & $x$ & & & & & $x$ & & \\
\hline 10 & Arara-canindé (Ara ararauna) & Fratura fechada simples tibiotarso $D$ & FI - PIM & & & & $\mathrm{x}$ & & & & $x$ & & & & $\mathrm{x}$ & \\
\hline 11 & Papagaio (Amazona sp.) & Fratura fechada simples tibiotarso $\mathrm{E}$ & $\mathrm{FI}-\mathrm{PIM}$ & & & & $\mathrm{x}$ & & & & $x$ & & & & $\mathrm{x}$ & \\
\hline 12 & Papagaio (Amazona sp.) & Fratura exposta simples úmero $\mathrm{D}$ & FE - T bipolar & & & & $\mathrm{x}$ & & & $x$ & & & & & $x$ & \\
\hline 13 & Papagaio (Amazona sp.) & Fratura fechada simples úmero $\mathrm{E}$ & $\mathrm{FI}-\mathrm{PIM}$ & & & & $x$ & & & & $x$ & & & & $\mathrm{x}$ & \\
\hline 14 & Curica, papagaio (Amazona amazonica) & Luxação fechada joelho E & Artrotomia + T unipolar & $x$ & & & & & & & $x$ & & & & $\mathrm{x}$ & \\
\hline 19 & Papagaio (Amazona sp.) & Fratura fechada simples fêmur D & $\mathrm{FI}-\mathrm{PIM}$ & & & & $\mathrm{x}$ & & & & $x$ & & & & $\mathrm{x}$ & \\
\hline 20 & Tucano-toco (Ramphastos toco) & Fratura fechada dupla fêmur $E$ & $\mathrm{FI}-\mathrm{PIM}$ & & & & $x$ & & & & $x$ & & & & $\mathrm{x}$ & \\
\hline 21 & Arara-canindé (Ara ararauna) & Fratura fechada simples tibiotarso $\mathrm{E}$ & FI - PIM & & & & $x$ & & & & $x$ & & & & $x$ & \\
\hline 22 & Periquito-verde (Brotogeris sp.) & $\begin{array}{l}\text { Fratura exposta simples tibiotarso E } \\
\text { (antiga) }\end{array}$ & $\mathrm{FI}-\mathrm{EOH}$ & & & $x$ & & & & $x$ & & & & & $\mathrm{x}$ & \\
\hline 23 & Papagaio (Amazona sp.) & Fratura fechada simples fêmur D & $\mathrm{FI}-\mathrm{PIM}$ & $\mathrm{x}$ & & & & $\mathrm{x}$ & & & & & & & $\mathrm{x}$ & \\
\hline 24 & Carcará (Caracara plancus) & Fratura exposta dupla úmero $\mathrm{E}$ & $\begin{array}{l}\mathrm{FI} \text { - polímero + } \mathrm{Ce}+\mathrm{HCe} \\
\mathrm{FE} \text { - T unipolar }\end{array}$ & & & & $\mathrm{x}$ & & & & $x$ & & & & $x$ & \\
\hline 25 & $\begin{array}{l}\text { Arara-azul-grande (Anodorhynchus } \\
\text { hyacinthinus *) }\end{array}$ & Fratura fechada simples tibiotarso $D$ & $\mathrm{FI}-\mathrm{PIM}+\mathrm{Ce}$ & & & & $\mathrm{x}$ & & & & $\mathrm{x}$ & & & & $x$ & \\
\hline 26 & Curica, papagaio (Amazona amazonica) & Fratura fechada simples fêmur $E$ & FI - PIM & & & $x$ & & & & & $\mathrm{x}$ & & & & $\mathrm{x}$ & \\
\hline \multicolumn{4}{|c|}{ Total } & 3 & 0 & 3 & 10 & 2 & 1 & 2 & 11 & 0 & 0 & 1 & 15 & 0 \\
\hline
\end{tabular}

*espécies da Fauna Brasileira ameaçadas de extinção; E - esquerdo; D - direito; MPB - membros pélvicos bilateral; SI - sem informação;

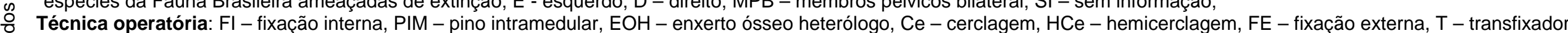

Consolidação: 0 - não união, 1 - reação periostal, 2 - calo ósseo:

Eixo ósseo: 0 - ruim (grande desvio do eixo ósseo), 1 - satisfatório (pequeno desvio do eixo ósseo), 2 - excelente (eixo ósseo mantido sem desvios);

Retorno à função: 0 - ausente, 1 - parcial, 2 - total, 3 - óbito 

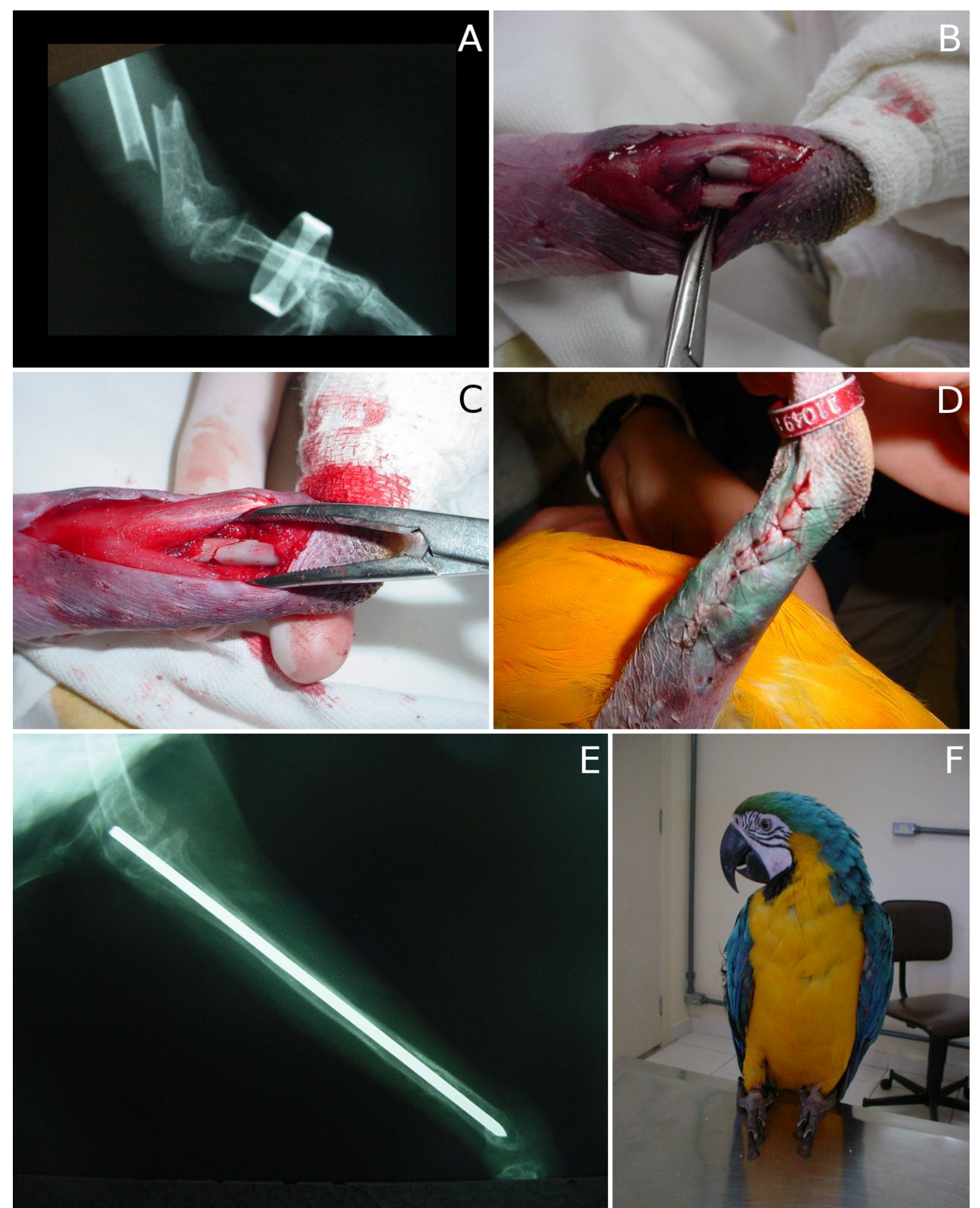

Foto: CASTRO, P. F. (2010)

Figura 1 - Fratura fechada simples de tibiotarso direito em arara-canindé (Ara ararauna). (A) Detalhe da imagem radiográfica do tibiotarso fraturado em sua porção médio distal em projeção lateral. (B) Trans-operatório: foco da fratura com fragmentos ósseos justapostos. (C) Trans-operatório: foco da fratura após sua redução e estabilização. (D) Hematoma e sutura cutânea aos sete dias de pós-operatório. (E) Imagem radiográfica em projeção lateral do tibiotarso consolidado com presença de pino IM e (F) paciente com apoio normal do membro operado, aos 67 dias de pós-operatório (Caso n¹0) 


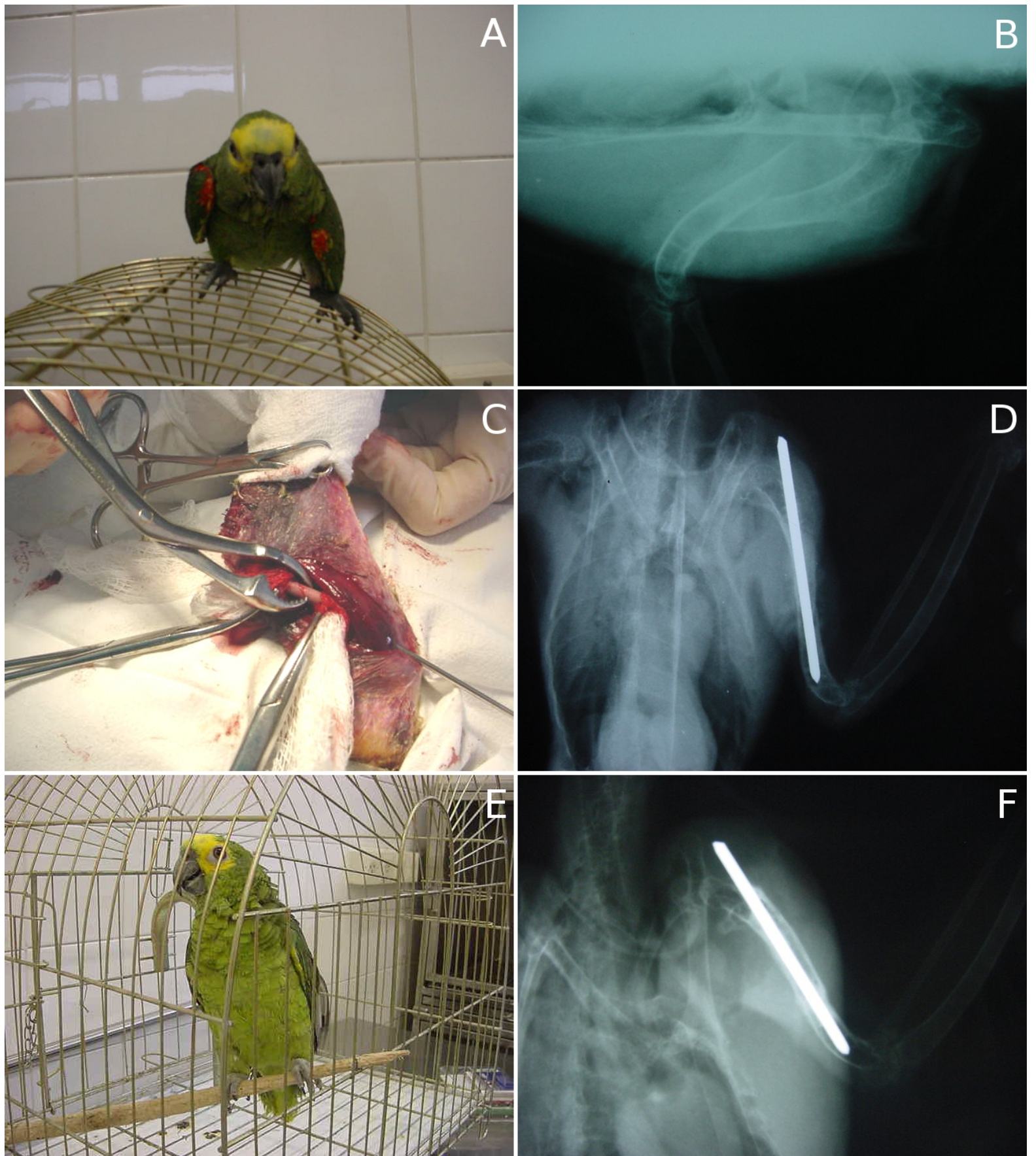

Foto: CASTRO, P. F. (2010)

Figura 2 - Fratura fechada simples de úmero esquerdo em papagaio (Amazona sp.). (A) Paciente com asa esquerda caída. (B) Imagem radiográfica do úmero fraturado em terço médio em projeção lateral. (C) Trans-operatório: foco da fratura durante sua redução e estabilização com pino IM. (D) Imagem radiográfica ventro-dorsal do úmero aos 15 dias de pósoperatório com visualização de pino IM, manutenção do eixo e calo ósseo em evolução. (E) Paciente exibe posicionamento normal da asa operada e a (F) imagem radiográfica mostra a presença do pino IM e consolidação óssea em projeção ventro-dorsal, aos 80 dias de pós-operatório (Caso no ${ }^{13}$ ) 



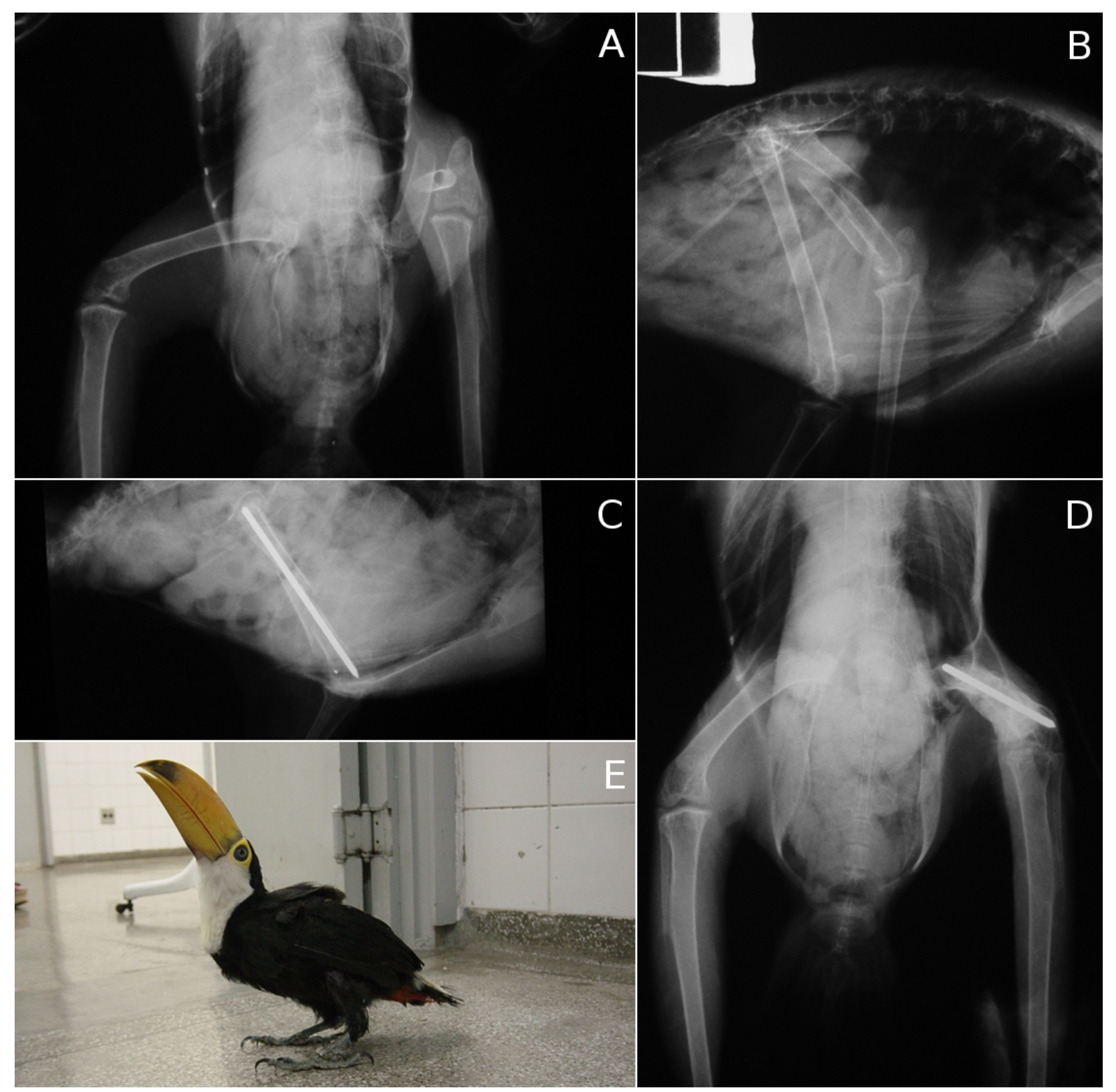

Foto: CASTRO, P. F. (2010)

Figura 3 - Fratura fechada dupla de fêmur esquerdo em tucano-toco (Ramphastos toco). (A) Imagem radiográfica da fratura dupla de fêmur em projeção ventro-dorsal e (B) lateral. (C) Radiografia em projeção lateral na qual se visualiza o pino IM e a redução da fratura com manutenção do eixo ósseo do fêmur, 24 horas após a realização da osteossíntese. (D) Imagem radiográfica do pino IM e calo ósseo em evolução no fêmur em projeção ventrodorsal e (E) paciente apresentando apoio normal do membro operado, 28 dias após a realização do procedimento cirúrgico $\left(\right.$ Caso $\left.n^{\circ} 20\right)$ 


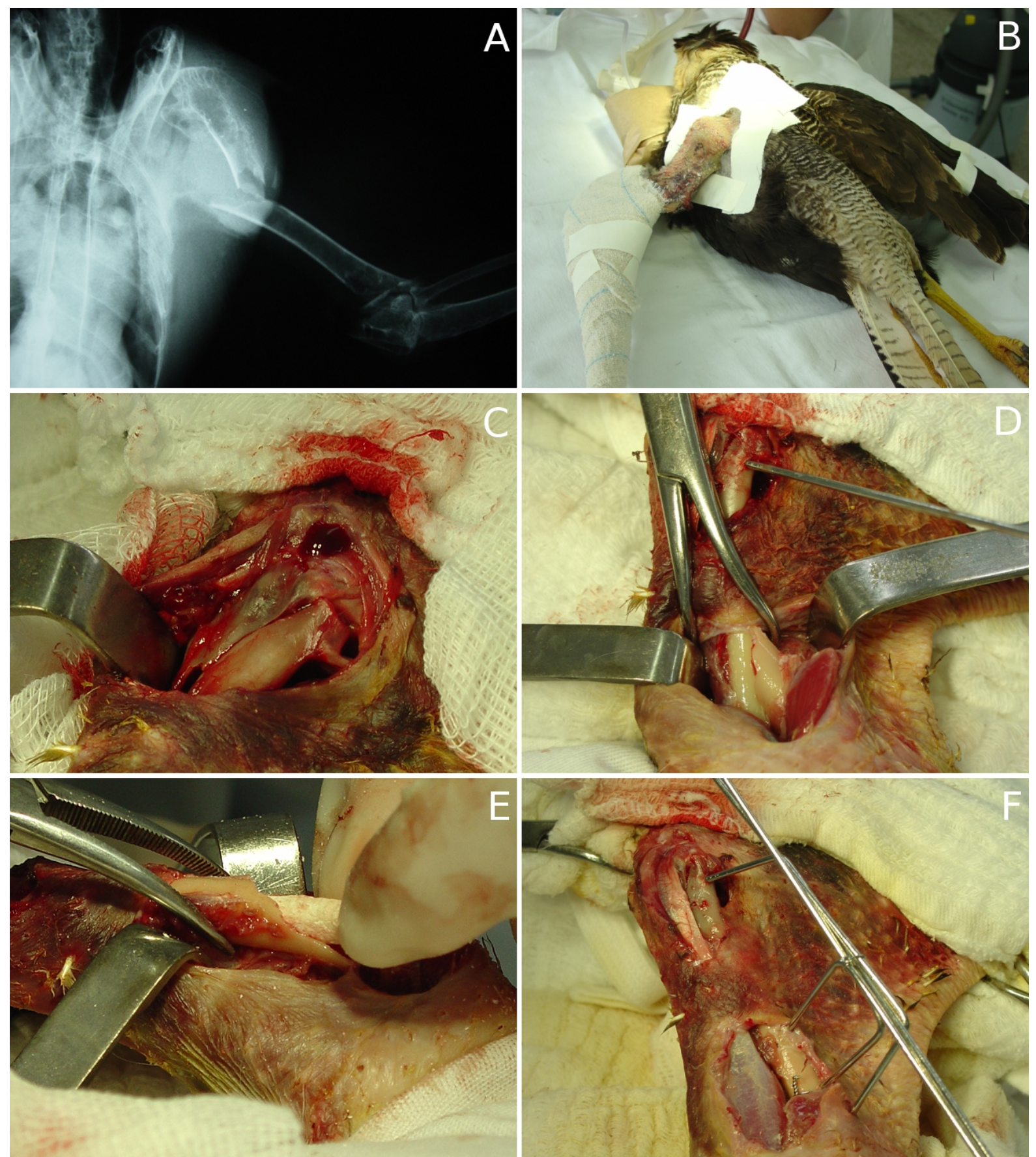

Foto: CASTRO, P. F. (2010)

Figura 4 - Fratura exposta dupla de úmero esquerdo em carcará (Caracara plancus). (A) Imagem radiográfica do úmero fraturado em terço proximal e distal em projeção ventro-dorsal. (B) Paciente anestesiado e posicionado em decúbito ventral e sítio operatório preparado para a osteossíntese. (C) Trans-operatório: foco da fratura distal com fragmentos ósseos justapostos. (D) Trans-operatório: fratura distal reduzida com visualização de pino de aço transfixante e foco da fratura proximal com desvio dos fragmentos ósseos. (E) Transoperatório: polímero de mamona sendo introduzido no canal medular de um dos fragmentos ósseos da fratura proximal. (F) Trans-operatório: estabilização das fraturas com transfixador externo unipolar (Caso $\left.n^{\circ} 24\right)$ 



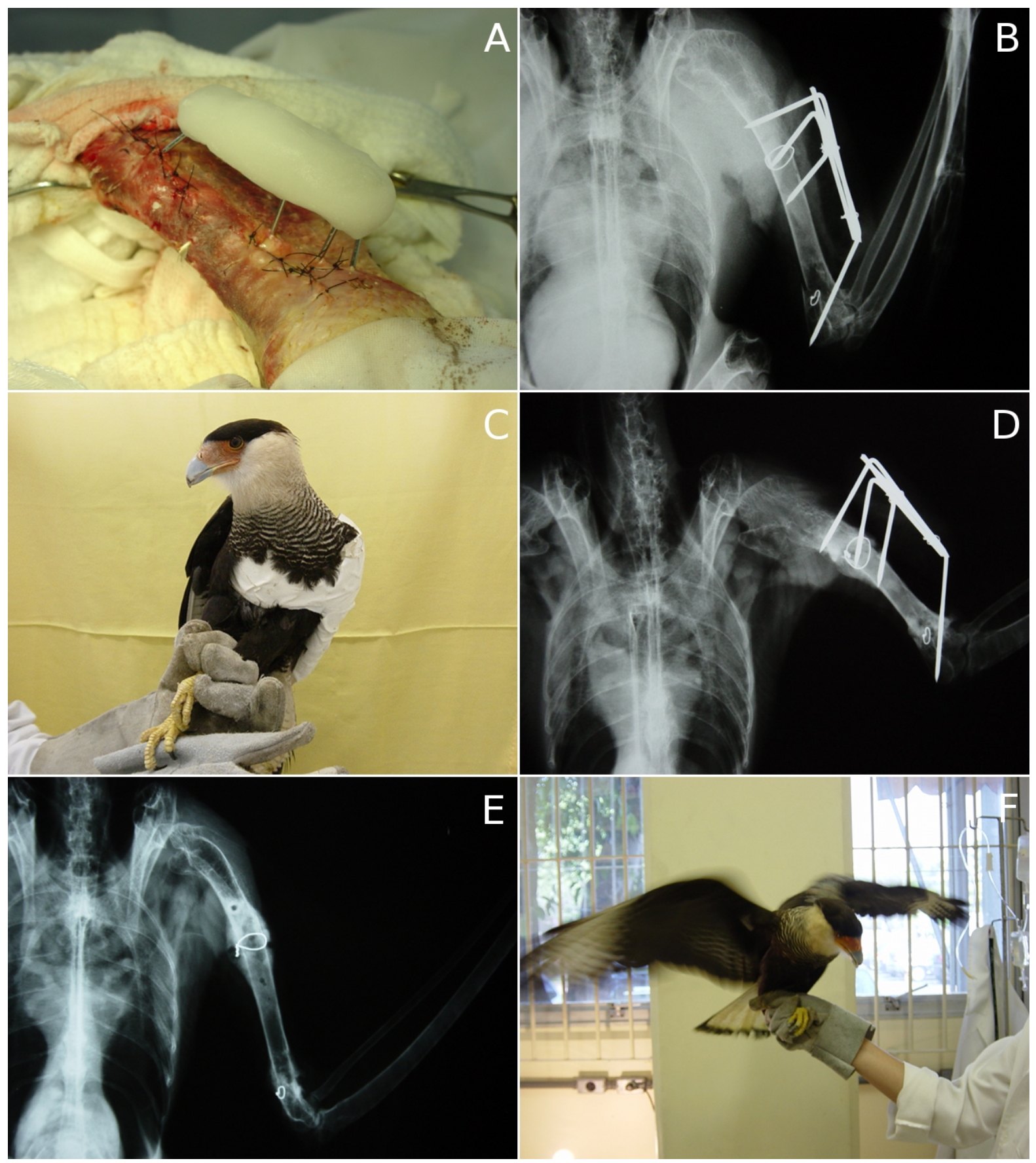

Foto: CASTRO, P. F. (2010)

Figura 5 - Continuação da figura 4: fratura exposta dupla de úmero esquerdo em carcará (Caracara plancus). (A) Trans-operatório: fixador externo unipolar confeccionado com barra de conexão de polimetilmetacrilato e síntese cutânea padrão ponto-simples-separado. (B) Imagem radiográfica do úmero em projeção ventro-dorsal realizada no pós-operatório imediato que mostra redução adequada da fratura dupla com eixo ósseo mantido. (C) Bandagem de contenção da asa aos sete dias de pós-operatório. (D) Imagem radiográfica do úmero em projeção ventro-dorsal realizada no $30^{\circ}$ dia de pós-operatório com visualização dos implantes e calo ósseo em foco proximal e distal da fratura. (E) Imagem radiográfica do úmero em projeção ventro-dorsal após ter sido retirado o transfixador externo, com manutenção do eixo ósseo e (F) paciente exibindo amplitude normal da asa operada, aos 33 dias de pós-operatório (Caso no 24) 



\subsection{TECIDOS MOLES}

A análise dos dados referentes às 63 operações para diagnóstico e/ou tratamento de afecções de tecidos moles permitiu identificar diferentes tipos de afecções de tecidos moles que estão relacionadas na tabela 10.

Tabela 10 - Distribuição numérica $(\mathrm{N})$ e percentual (\%) quanto ao tipo do total de afecções cirúrgicas de tecidos moles das aves operadas - São Paulo janeiro de 2000 a junho de 2008

\begin{tabular}{lcc}
\hline \multicolumn{1}{c}{ Afecção de tecidos moles } & N & $\%$ \\
\hline Neoplasias & 19 & 30,16 \\
Neoformações cutâneas ou de anexos não neoplásicos & 11 & 17,46 \\
Neoformações cutâneas sem diagnóstico & 5 & 7,94 \\
"Necrose avascular de dígito" & 1 & 1,59 \\
Ferida na região da quilha & 1 & 1,59 \\
Gangrena de extremidade de membros & 2 & 3,17 \\
Hérnia abdominal & 3 & 4,76 \\
Perfuração de cavidade celomática & 1 & 1,59 \\
Neoformação em cavidade celomática sem diagnóstico & 1 & 1,59 \\
Distocia & 5 & 7,94 \\
Fístula de papo & 5 & 7,94 \\
Perfuração de esôfago & 2 & 3,17 \\
CE em trato gastrointestinal & 1 & 1,59 \\
Prolapso de cloaca & 2 & 3,17 \\
Sinusite & 3 & 4,76 \\
Otite & 1 & 1,59 \\
\hline \hline
\end{tabular}


$\mathrm{Na}$ tabela 11 encontram-se discriminados os diagnósticos histopatológicos firmado pelo Serviço de Patologia Animal do HOVET-FMVZ/USP das 19 neoplasias operadas.

Tabela 11 - Distribuição numérica $(\mathrm{N})$ e percentual (\%) quanto ao diagnóstico histopatológico das 19 neoplasias de tecidos moles das aves operadas - São Paulo - janeiro de 2000 a junho de 2008

\begin{tabular}{|c|c|c|}
\hline Neoplasias & $\mathbf{N}$ & $\%$ \\
\hline Lipoma & 13 & 68,42 \\
\hline Linfoma & 2 & 10,53 \\
\hline Lipossarcoma & 1 & 5,26 \\
\hline Hemangiossarcoma & 1 & 5,26 \\
\hline Carcinoma de células escamosas & 1 & 5,26 \\
\hline Melanoma & 1 & 5,26 \\
\hline Total & 19 & 100,00 \\
\hline
\end{tabular}

$\mathrm{Na}$ tabela 12 encontram-se discriminados os diagnósticos histopatológicos firmado pelo Serviço de Patologia Animal do HOVET-FMVZ/USP das 11 neoformações cutâneas ou de anexos não neoplásicos operadas.

Tabela 12 - Distribuição numérica $(N)$ e percentual (\%) quanto ao diagnóstico histopatológico das 11 neoformações cutâneas ou de anexos não neoplásicos de tecidos moles das aves operadas - São Paulo - janeiro de 2000 a junho de 2008

\begin{tabular}{lccc}
\hline \hline Neoformações cutâneas ou de anexos não neoplásicos & N & \% \\
\hline \hline Cáseo & 6 & 54,55 \\
Cisto infundibular ("cisto de pena") & 3 & 27,27 \\
Xantoma & 1 & 9,09 \\
Tuberculose (lesão granulomatosa) & 1 & 9,09 \\
\hline \hline \multicolumn{1}{c}{ Total } & $\mathbf{1 1}$ & $\mathbf{1 0 0 , 0 0}$ \\
\hline \hline
\end{tabular}


A distribuição das afecções cirúrgicas de tecidos moles com a descrição e as localizações corpóreas na qual ocorreram encontra-se na tabela 13.

Tabela 13 - Distribuição numérica $(N)$ e percentual (\%) do total de casos de afecções cirúrgicas de tecidos moles de aves operadas segundo descrição e localização - São Paulo - janeiro de 2000 a junho de 2008

\begin{tabular}{|c|c|c|c|}
\hline Afecção de tecidos moles & Localização & $\mathbf{N}$ & $\%$ \\
\hline Carcinoma de células escamosas & Cavidade oral & 1 & 1,59 \\
\hline Hemangiossarcoma cutâneo bem diferenciado & Membro pélvico & 1 & 1,59 \\
\hline Linfoma & $\begin{array}{l}\text { Peitoral } \\
\text { Tibiotarso distal }\end{array}$ & $\begin{array}{l}1 \\
1\end{array}$ & $\begin{array}{l}1,59 \\
1,59\end{array}$ \\
\hline Lipoma cutâneo & $\begin{array}{l}\text { Abdominal } \\
\text { Pericloacal } \\
\text { Abdominal e pericloacal } \\
\text { Pericloacal e m. pélvico } \\
\text { Dorso }\end{array}$ & $\begin{array}{l}1 \\
7 \\
3 \\
1 \\
1\end{array}$ & $\begin{array}{c}1,59 \\
11,11 \\
4,76 \\
1,59 \\
1,59\end{array}$ \\
\hline Lipossarcoma cutâneo & Pericloacal & 1 & 1,59 \\
\hline Melanoma & Mandíbula & 1 & 1,59 \\
\hline Cáseo & $\begin{array}{l}\text { Submandibular } \\
\text { Cervical } \\
\text { Peitoral } \\
\text { Cavidade oral } \\
\text { Sem informação }\end{array}$ & $\begin{array}{l}1 \\
2 \\
1 \\
1 \\
1\end{array}$ & $\begin{array}{l}1,59 \\
3,17 \\
1,59 \\
1,59 \\
1,59\end{array}$ \\
\hline Cisto infundibular ("cisto de pena") & $\begin{array}{l}\text { Cera ou carúnculo } \\
\text { Cauda } \\
\text { Sem informação }\end{array}$ & $\begin{array}{l}1 \\
1 \\
1\end{array}$ & $\begin{array}{l}1,59 \\
1,59 \\
1,59\end{array}$ \\
\hline Xantoma & Peitoral & 1 & 1,59 \\
\hline Tuberculose (lesão granulomatosa) & Tibiotarso distal & 1 & 1,59 \\
\hline Neoformações cutâneas & $\begin{array}{l}\text { Asa } \\
\text { Cervical } \\
\text { Pericloacal }\end{array}$ & $\begin{array}{l}3 \\
1 \\
1\end{array}$ & $\begin{array}{l}4,76 \\
1,59 \\
1,59\end{array}$ \\
\hline "Necrose Avascular de Dígito" (dermatite hiperplásica) & Dígito membro pélvico & 1 & 1,59 \\
\hline Ferida por mordedura & Quilha & 1 & 1,59 \\
\hline Gangrena de extremidade de membro & Membro pélvico & 2 & 3,17 \\
\hline Hérnia abdominal & Abdominal & 3 & 4,76 \\
\hline Perfuração de cavidade celomática por mordedura & Cavidade celomática & 1 & 1,59 \\
\hline Neoformação em cavidade celomática & Cavidade celomática & 1 & 1,59 \\
\hline Distocia & Cavidade celomática & 5 & 7,94 \\
\hline Fístula de papo por queimadura & Inglúvio & 2 & 3,17 \\
\hline Fistula de papo recidivante por queimadura & Inglúvio & 3 & 4,76 \\
\hline Perfuração de esôfago por corpo estranho & Esôfago cervical & 1 & 1,59 \\
\hline Perfuração de esôfago por mordedura & Esôfago cervical & 1 & 1,59 \\
\hline CE (sonda para alimentação) em trato gastrointestinal & Proventrículo e ventrículo & 1 & 1,59 \\
\hline Prolapso de cloaca & Cloaca & 2 & 3,17 \\
\hline Sinusite & Seios infraorbitais & 3 & 4,76 \\
\hline Otite & Ouvido externo & 1 & 1,59 \\
\hline \multicolumn{2}{|l|}{ Total } & 63 & 100,00 \\
\hline
\end{tabular}


A ocorrência dos diferentes tipos de afecções cirúrgicas de tecidos moles segundo as ordens as quais pertencem as espécies operadas encontra-se na tabela 14 a seguir:

Tabela 14 - Distribuição numérica $(N)$ e percentual (\%) dos casos de afecções cirúrgicas de tecidos moles de aves operadas segundo as ordens São Paulo - janeiro de 2000 a junho de 2008

\begin{tabular}{|c|c|c|c|c|c|c|c|c|c|c|}
\hline \multirow{2}{*}{$\begin{array}{l}\text { Afecção de tecidos } \\
\text { moles }\end{array}$} & \multicolumn{2}{|c|}{ Psittaciformes } & \multicolumn{2}{|c|}{ Anseriformes } & \multicolumn{2}{|c|}{ Columbiformes } & \multicolumn{2}{|c|}{ Passeriformes } & \multicolumn{2}{|c|}{ Total } \\
\hline & $\mathbf{N}$ & $\%$ & $\mathbf{N}$ & $\%$ & $\mathbf{N}$ & $\%$ & $\mathbf{N}$ & $\%$ & $\mathbf{N}$ & $\%$ \\
\hline Neoplasias & 19 & 30,16 & 0 & 0,00 & 0 & 0,00 & 0 & 0,00 & 19 & 30,16 \\
\hline $\begin{array}{l}\text { Neoformações cutâneas } \\
\text { ou de anexos não } \\
\text { neoplásicos }\end{array}$ & 11 & 17,46 & 0 & 0,00 & 0 & 0,00 & 0 & 0,00 & 11 & 17,46 \\
\hline $\begin{array}{l}\text { Neoformações cutâneas } \\
\text { sem diagnóstico }\end{array}$ & 5 & 7,94 & 0 & 0,00 & 0 & 0,00 & 0 & 0,00 & 5 & 7,94 \\
\hline $\begin{array}{l}\text { "Necrose avascular de } \\
\text { dígito" }\end{array}$ & 1 & 1,59 & 0 & 0,00 & 0 & 0,00 & 0 & 0,00 & 1 & 1,59 \\
\hline $\begin{array}{l}\text { Ferida na região da } \\
\text { quilha }\end{array}$ & 1 & 1,59 & 0 & 0,00 & 0 & 0,00 & 0 & 0,00 & 1 & 1,59 \\
\hline $\begin{array}{l}\text { Gangrena de } \\
\text { extremidade de membros }\end{array}$ & 2 & 3,17 & 0 & 0,00 & 0 & 0,00 & 0 & 0,00 & 2 & 3,17 \\
\hline Hérnia abdominal & 2 & 3,17 & 1 & 1,59 & 0 & 0,00 & 0 & 0,00 & 3 & 4,76 \\
\hline $\begin{array}{l}\text { Perfuração de cavidade } \\
\text { celomática }\end{array}$ & 1 & 1,59 & 0 & 0,00 & 0 & 0,00 & 0 & 0,00 & 1 & 1,59 \\
\hline $\begin{array}{l}\text { Neoformações em } \\
\text { cavidade celomática sem } \\
\text { diagnóstico }\end{array}$ & 1 & 1,59 & 0 & 0,00 & 0 & 0,00 & 0 & 0,00 & 1 & 1,59 \\
\hline Distocia & 2 & 3,17 & 0 & 0,00 & 1 & 1,59 & 2 & 3,17 & 5 & 7,94 \\
\hline Fístula de papo & 5 & 7,94 & 0 & 0,00 & 0 & 0,00 & 0 & 0,00 & 5 & 7,94 \\
\hline Perfuração de esôfago & 1 & 1,59 & 0 & 0,00 & 1 & 1,59 & 0 & 0,00 & 2 & 3,17 \\
\hline $\begin{array}{l}\text { Corpo estranho em trato } \\
\text { gastrointestinal }\end{array}$ & 1 & 1,59 & 0 & 0,00 & 0 & 0,00 & 0 & 0,00 & 1 & 1,59 \\
\hline Prolapso de cloaca & 2 & 3,17 & 0 & 0,00 & 0 & 0,00 & 0 & 0,00 & 2 & 3,17 \\
\hline Sinusite & 3 & 4,76 & 0 & 0,00 & 0 & 0,00 & 0 & 0,00 & 3 & 4,76 \\
\hline Otite & 1 & 1,59 & 0 & 0,00 & 0 & 0,00 & 0 & 0,00 & 1 & 1,59 \\
\hline Total & 58 & 92,06 & 1 & 1,59 & 2 & 3,17 & 2 & 3,17 & 63 & 100,00 \\
\hline
\end{tabular}


Quanto à distribuição dos tipos de afecções cirúrgicas de tecidos moles segundo as espécies acometidas observou-se apenas um caso de hérnia abdominal ocorrido em um pato-doméstico (Cairina moschata) da ordem Anseriformes que representou 1,58\% (1/63), um caso de distocia e outro de perfuração de esôfago em dois pombos-domésticos (Columba livia) da ordem Columbiformes que representaram 3,17\% (2/63) e dois casos de distocia em dois canários-do-reino (Serinus canaria) da ordem Passeriformes que representaram 3,17\% (2/63), sendo que $92,06 \%$ (58/63) dos casos restantes ocorreram em espécies pertencentes a ordem Psittaciformes e encontram-se na tabela 15, na qual se observa o "grupo dos papagaios", para o qual se considerou todos os exemplares pertencentes aos gêneros Amazona e Deroptyus, como prevalente representando 74,6\% (47/63) dos casos e 81,03\% (47/58) das espécies de psitaciformes. Imagens de neoplasias (Figura 6) e de neoformações cutâneas ou de anexos não neoplásicos (Figura 7) que acometeram espécimes do "grupo dos papagaios" são apresentadas. 
Tabela 15 - Distribuição numérica (N) e percentual (\%) quanto ao tipo das 58 afecções cirúrgicas de tecidos moles operadas em psitaciformes segundo as espécies - São Paulo - janeiro de 2000 a junho de 2008

\begin{tabular}{|c|c|c|c|c|c|c|c|c|c|c|c|c|c|c|c|c|c|c|c|c|c|c|c|c|c|c|c|c|c|c|c|c|c|c|}
\hline \multirow{2}{*}{$\begin{array}{l}\text { Nome comum } \\
\text { Nome científico }\end{array}$} & \multicolumn{2}{|c|}{$\mathbf{N}$} & \multicolumn{2}{|c|}{ NCNP } & \multicolumn{2}{|c|}{ NCSD } & \multicolumn{2}{|c|}{ NAD } & \multicolumn{2}{|c|}{$\mathrm{FQ}$} & \multicolumn{2}{|c|}{ GEM } & \multicolumn{2}{|c|}{ HA } & \multicolumn{2}{|c|}{ PCC } & \multicolumn{2}{|c|}{ NCC } & \multicolumn{2}{|c|}{ D } & \multicolumn{2}{|c|}{ FP } & \multicolumn{2}{|c|}{ PE } & \multicolumn{2}{|c|}{ CETGI } & \multicolumn{2}{|c|}{ PC } & \multicolumn{2}{|c|}{$\mathbf{S}$} & \multicolumn{2}{|c|}{ Otite } & \multicolumn{2}{|c|}{ Total } \\
\hline & $\mathbf{N}$ & $\%$ & $\mathbf{N}$ & $\%$ & $\mathbf{N}$ & $\%$ & $\mathbf{N}$ & $\%$ & 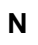 & $\%$ & $N$ & $\%$ & $\mathbf{N}$ & $\%$ & $\mathbf{N}$ & $\%$ & $\mathbf{N}$ & $\%$ & $\mathbf{N}$ & $\%$ & $\mathbf{N}$ & $\%$ & $N$ & $\%$ & $N$ & $\%$ & $\mathbf{N}$ & $\%$ & $\mathbf{N}$ & $\%$ & $\mathbf{N}$ & $\%$ & $\mathbf{N}$ & $\%$ \\
\hline $\begin{array}{l}\text { \#Papagaio-verdadeiro } \\
\text { Amazona aestiva }\end{array}$ & 7 & 12,07 & 8 & 13,79 & 1 & 1,72 & 0 & 0,00 & 1 & 1,72 & 0 & 0,00 & 1 & 1,72 & 1 & 1,72 & 1 & 1,72 & 1 & 1,72 & 2 & 3,45 & 0 & 0,00 & 1 & 1,72 & 2 & 3,45 & 0 & 0,00 & 1 & 1,72 & 27 & 46,55 \\
\hline $\begin{array}{l}\text { \#Curica, papagaio } \\
\text { Amazona amazonica }\end{array}$ & 6 & 10,34 & 1 & 1,72 & 0 & 0,00 & 0 & 0,00 & 0 & 0,00 & 0 & 0,00 & 0 & 0,00 & 0 & 0,00 & 0 & 0,00 & 0 & 0,00 & 0 & 0,00 & 0 & 0,00 & 0 & 0,00 & 0 & 0,00 & 0 & 0,00 & 0 & 0,00 & 7 & 12,07 \\
\hline $\begin{array}{l}\text { \#Papagaio-de-cara-roxa } \\
\text { Amazona brasiliensis* }\end{array}$ & 0 & 0,00 & 0 & 0,00 & 0 & 0,00 & 0 & 0,00 & 0 & 0,00 & 0 & 0,00 & 0 & 0,00 & 0 & 0,00 & 0 & 0,00 & 0 & 0,00 & 0 & 0,00 & 0 & 0,00 & 0 & 0,00 & 0 & 0,00 & 1 & 1,72 & 0 & 0,00 & 1 & 1,72 \\
\hline $\begin{array}{l}\text { \#Papagaio-campeiro } \\
\text { Amazona ochrocephala }\end{array}$ & 0 & 0,00 & 0 & 0,00 & 1 & 1,72 & 0 & 0,00 & 0 & 0,00 & 0 & 0,00 & 0 & 0,00 & 0 & 0,00 & 0 & 0,00 & 0 & 0,00 & 0 & 0,00 & 0 & 0,00 & 0 & 0,00 & 0 & 0,00 & 0 & 0,00 & 0 & 0,00 & 1 & 1,72 \\
\hline $\begin{array}{l}\text { \#Papagaio } \\
\text { Amazona sp. }\end{array}$ & 3 & 5,17 & 2 & 3,45 & 1 & 1,72 & 0 & 0,00 & 0 & 0,00 & 0 & 0,00 & 0 & 0,00 & 0 & 0,00 & 0 & 0,00 & 1 & 1,72 & 1 & 1,72 & 0 & 0,00 & 0 & 0,00 & 0 & 0,00 & 2 & 3,45 & 0 & 0,00 & 10 & 17,24 \\
\hline $\begin{array}{l}\text { \#Anacã } \\
\text { Deroptyus accipitrinus }\end{array}$ & 0 & 0,00 & 0 & 0,00 & 0 & 0,00 & 0 & 0,00 & 0 & 0,00 & 0 & 0,00 & 0 & 0,00 & 0 & 0,00 & 0 & 0,00 & 0 & 0,00 & 1 & 1,72 & 0 & 0,00 & 0 & 0,00 & 0 & 0,00 & 0 & 0,00 & 0 & 0,00 & 1 & 1,72 \\
\hline $\begin{array}{l}\text { Arara-canindé } \\
\text { Ara ararauna }\end{array}$ & 1 & 1,72 & 0 & 0,00 & 0 & 0,00 & 1 & 1,72 & 0 & 0,00 & 0 & 0,00 & 0 & 0,00 & 0 & 0,00 & 0 & 0,00 & 0 & 0,00 & 0 & 0,00 & 1 & 1,72 & 0 & 0,00 & 0 & 0,00 & 0 & 0,00 & 0 & 0,00 & 3 & 5,17 \\
\hline $\begin{array}{l}\text { Arara-vermelha } \\
\text { Ara macao }\end{array}$ & 0 & 0,00 & 0 & 0,00 & 0 & 0,00 & 0 & 0,00 & 0 & 0,00 & 0 & 0,00 & 0 & 0,00 & 0 & 0,00 & 0 & 0,00 & 0 & 0,00 & 1 & 1,72 & 0 & 0,00 & 0 & 0,00 & 0 & 0,00 & 0 & 0,00 & 0 & 0,00 & 1 & 1,72 \\
\hline $\begin{array}{l}\text { Periquito-verde } \\
\text { Brotogeris sp. }\end{array}$ & 0 & 0,00 & 0 & 0,00 & 0 & 0,00 & 0 & 0,00 & 0 & 0,00 & 1 & 1,72 & 0 & 0,00 & 0 & 0,00 & 0 & 0,00 & 0 & 0,00 & 0 & 0,00 & 0 & 0,00 & 0 & 0,00 & 0 & 0,00 & 0 & 0,00 & 0 & 0,00 & 1 & 1,72 \\
\hline $\begin{array}{l}\text { Maracanã-pequena } \\
\text { Diopsittaca nobilis }\end{array}$ & 1 & 1,72 & 0 & 0,00 & 0 & 0,00 & 0 & 0,00 & 0 & 0,00 & 0 & 0,00 & 0 & 0,00 & 0 & 0,00 & 0 & 0,00 & 0 & 0,00 & 0 & 0,00 & 0 & 0,00 & 0 & 0,00 & 0 & 0,00 & 0 & 0,00 & 0 & 0,00 & 1 & 1,72 \\
\hline $\begin{array}{l}\text { Periquito-australiano } \\
\text { Melopsittacus } \\
\text { undulatus }\end{array}$ & 0 & 0,00 & 0 & 0,00 & 1 & 1,72 & 0 & 0,00 & 0 & 0,00 & 1 & 1,72 & 1 & 1,72 & 0 & 0,00 & 0 & 0,00 & 0 & 0,00 & 0 & 0,00 & 0 & 0,00 & 0 & 0,00 & 0 & 0,00 & 0 & 0,00 & 0 & 0,00 & 3 & 5,17 \\
\hline $\begin{array}{l}\text { Calopsita } \\
\text { Nymphicus hollandicus }\end{array}$ & 0 & 0,00 & 0 & 0,00 & 1 & 1,72 & 0 & 0,00 & 0 & 0,00 & 0 & 0,00 & 0 & 0,00 & 0 & 0,00 & 0 & 0,00 & 0 & 0,00 & 0 & 0,00 & 0 & 0,00 & 0 & 0,00 & 0 & 0,00 & 0 & 0,00 & 0 & 0,00 & 1 & 1,72 \\
\hline $\begin{array}{l}\text { Rosela } \\
\text { Platycercus eximius }\end{array}$ & 1 & 1,72 & 0 & 0,00 & 0 & 0,00 & 0 & 0,00 & 0 & 0,00 & 0 & 0,00 & 0 & 0,00 & 0 & 0,00 & 0 & 0,00 & 0 & 0,00 & 0 & 0,00 & 0 & 0,00 & 0 & 0,00 & 0 & 0,00 & 0 & 0,00 & 0 & 0,00 & 1 & 1,72 \\
\hline Total & 19 & 32,76 & 11 & 18,97 & 5 & 8,62 & 1 & 1,72 & 1 & 1,72 & 2 & 3,45 & 2 & 3,45 & 1 & 1,72 & 1 & 1,72 & 2 & 3,45 & 5 & 8,62 & 1 & 1,72 & 1 & 1,72 & 2 & 3,45 & 3 & 5,17 & 1 & 1,72 & 58 & 100,00 \\
\hline
\end{tabular}

* espécie da Fauna Brasileira ameaçadas de extinção; \# espécies pertencentes ao gênero Amazona e Deroptyus que compõem o "grupo dos papagaios";

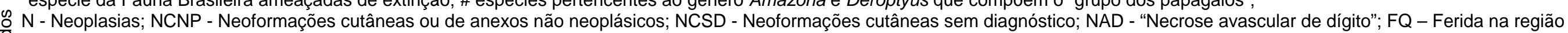

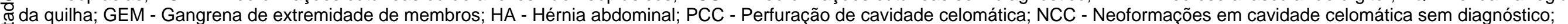
J D - Distocia; FP - Fístula de papo; PE - Perfuração de esôfago; CETGI - Corpo estranho em trato gastrointestinal; PC - Prolapso de cloaca; S - Sinusite 

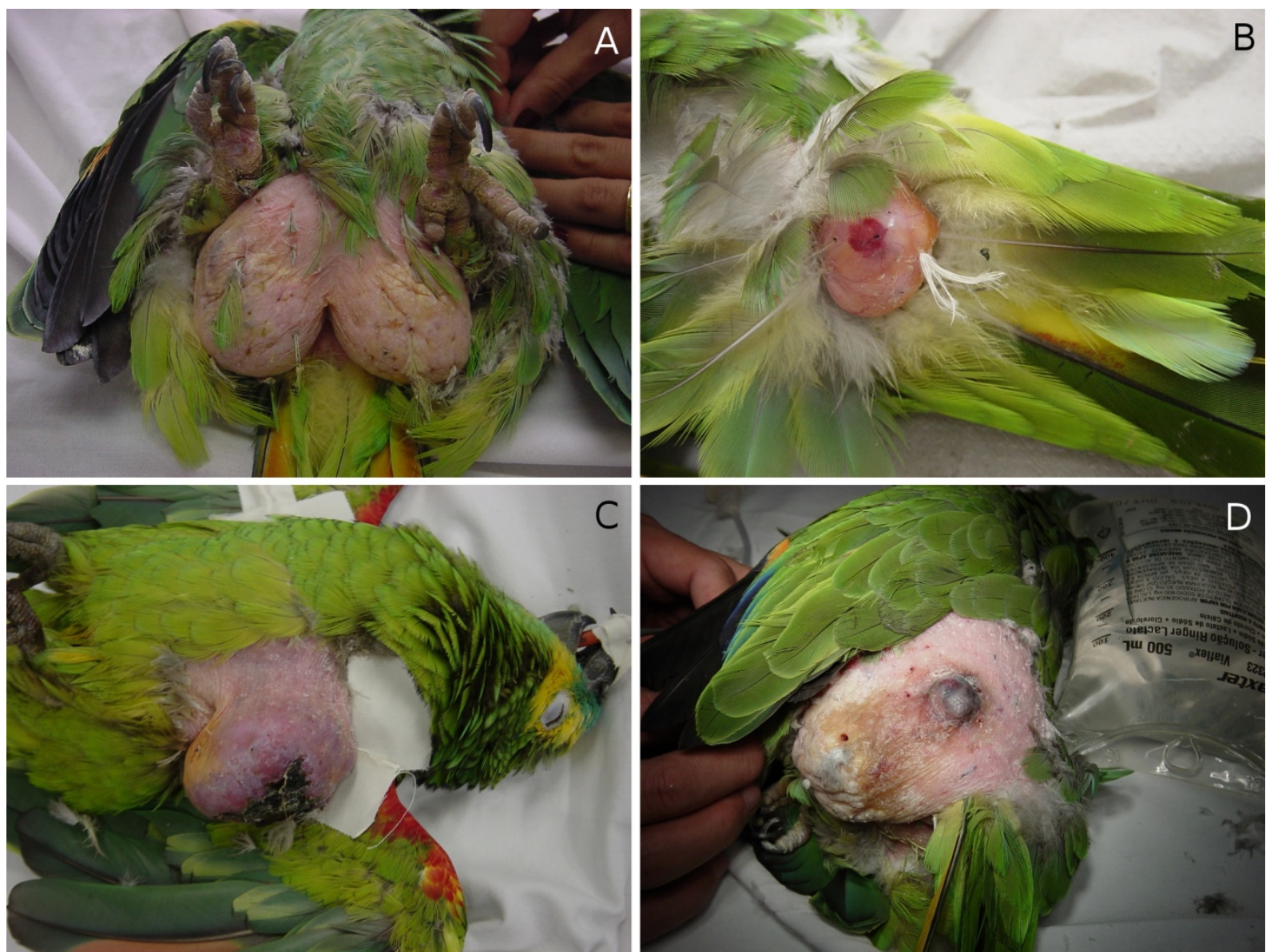

Foto: CASTRO, P. F. (2010)

Figura 6 - Fotografias de neoplasias de tecidos moles em aves do gênero Amazona. (A) Lipoma pericloacal em A. aestiva. (B) Lipoma na cauda de Amazona sp. (C) Linfoma cutâneo em $A$. aestiva. (D) Hemangiossarcoma bem diferenciado em membro pélvico de $A$. aestiva
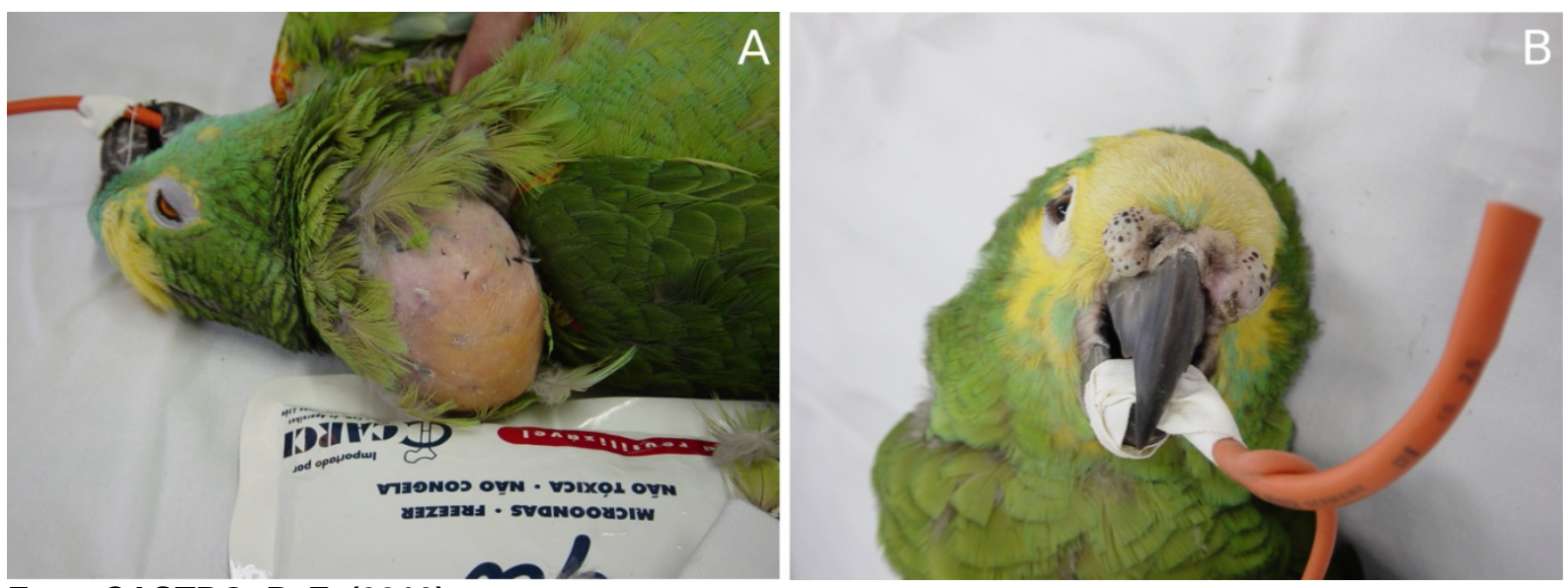

Foto: CASTRO, P. F. (2010)

Figura 7 - Fotografias de neoformações cutâneas ou de anexos não neoplásicos em aves da espécie papagaio-verdadeiro (Amazona aestiva). (A) Cáseo. (B) Cisto infundibular ("cisto de pena") em carúnculo 

O número de técnicas operatórias realizadas neste estudo para diagnóstico e/ou tratamento das afecções cirúrgicas de tecidos moles totalizou 71, representadas por 36,62\% (26/71) de exérese, 9,86\% (7/71) de colheita de material (HP e/ou CATB), 7,04\% (5/71) para cada uma das técnicas de ingluvioplastia, amputação e drenagem de cáseo, 5,63\% (4/71) de biópsia incisional, 4,23\% (3/71) tanto para herniorrafia abdominal como para celiotomia, 2,82\% (2/71) para cada uma das técnicas de esofagoplastia, endoscopia, redução de prolapso/sutura em bolsade-fumo e ovocentese, e por fim, 1,41\% (1/71) para cada uma das técnicas de laparorrafia, ingluviotomia, debridamento/síntese, crioterapia e colocação de sonda em saco aéreo. O número de técnicas operatórias foi 71 enquanto o de afecções de tecidos moles foi 63 , pois para diversas afecções foram utilizadas técnicas associadas. Os dados relacionados aos tipos de técnicas operatórias e sua ocorrência estão na tabela 16, a seguir: 
Tabela 16 - Distribuição numérica (N) e percentual (\%) quanto ao tipo de técnica operatória utilizada nas aves operadas segundo as afecções de tecidos moles - São Paulo - janeiro de 2000 a junho de 2008

\begin{tabular}{|c|c|c|c|c|c|c|c|c|c|c|c|c|c|c|c|c|c|c|c|c|c|c|c|c|c|c|c|c|c|c|c|c|c|c|c|c|c|}
\hline \multirow{3}{*}{$\begin{array}{c}\text { Afecção } \\
\text { de } \\
\text { tecidos } \\
\text { moles }\end{array}$} & \multicolumn{35}{|c|}{ Técnica operatória } & \multirow{2}{*}{\multicolumn{2}{|c|}{ Total }} \\
\hline & \multicolumn{2}{|c|}{ Ex } & \multicolumn{2}{|c|}{$\mathrm{Cm}$} & \multicolumn{2}{|c|}{ Ip } & \multicolumn{2}{|c|}{ Amp } & \multicolumn{2}{|c|}{ Dc } & \multicolumn{2}{|c|}{$\mathrm{Bi}$} & \multicolumn{2}{|c|}{$\mathrm{Hfa}$} & \multicolumn{2}{|c|}{$\mathrm{Ct}$} & \multicolumn{2}{|c|}{ Eso } & \multicolumn{2}{|c|}{ Endo } & \multicolumn{3}{|c|}{ Rps } & \multicolumn{2}{|c|}{ Ov } & \multicolumn{2}{|c|}{ Lap } & \multicolumn{2}{|c|}{ It } & \multicolumn{2}{|c|}{ Dbs } & \multicolumn{2}{|c|}{ Crio } & \multicolumn{2}{|c|}{ Saac } & & \\
\hline & $\mathbf{N}$ & $\%$ & $N$ & $\%$ & $N$ & $\%$ & $\mathrm{~N}$ & $\%$ & $\mathbf{N}$ & $\%$ & $\mathrm{~N}$ & $\%$ & $\mathrm{~N}$ & $\%$ & $\mathrm{~N}$ & $\%$ & $\mathrm{~N}$ & $\%$ & $\mathrm{~N}$ & $\%$ & 1 & $\%$ & & $\mathbf{N}$ & $\%$ & $N$ & $\%$ & $\mathbf{N}$ & $\%$ & $\mathbf{N}$ & $\%$ & $\mathbf{N}$ & $\%$ & $\mathbf{N}$ & $\%$ & $\mathbf{N}$ & $\%$ \\
\hline Neoplasias & 16 & 22,54 & 1 & 1,41 & 0 & 0,00 & 0 & 0,00 & 0 & 0,00 & 2 & 2,82 & 0 & 0,00 & 0 & 0,00 & 0 & 0,00 & 0 & 0,00 & c & 0, & & 0 & 0,00 & 0 & 0,00 & 0 & 0,00 & 0 & 0,00 & 1 & 1,41 & 0 & 0,00 & 20 & 28,17 \\
\hline NCNP & 8 & 11,27 & 2 & 2,82 & 0 & 0,00 & 0 & 0,00 & 1 & 1,41 & 1 & 1,41 & 0 & 0,00 & 0 & 0,00 & 0 & 0,00 & 0 & 0,00 & c & 0, & & 0 & 0,00 & 0 & 0,00 & 0 & 0,00 & 0 & 0,00 & 0 & 0,00 & 0 & 0,00 & 12 & 16,90 \\
\hline NCSD & 2 & 2,82 & 0 & 0,00 & 0 & 0,00 & 2 & 2,82 & 0 & 0,00 & 1 & 1,41 & 0 & 0,00 & 0 & 0,00 & 0 & 0,00 & 0 & 0,00 & $c$ & 0 & & 0 & 0,00 & 0 & 0,00 & 0 & 0,00 & 0 & 0,00 & 0 & 0,00 & 0 & 0,00 & 5 & 7,04 \\
\hline NAD & 0 & 0,00 & 0 & 0,00 & 0 & 0,00 & 1 & 1,41 & 0 & 0,00 & 0 & 0,00 & 0 & 0,00 & 0 & 0,00 & 0 & 0,00 & 0 & 0,00 & c & 0 & & 0 & 0,00 & 0 & 0,00 & 0 & 0,00 & 0 & 0,00 & 0 & 0,00 & 0 & 0,00 & 1 & 1,41 \\
\hline $\mathrm{FQ}$ & 0 & 0,00 & 0 & 0,00 & 0 & 0,00 & 0 & 0,00 & 0 & 0,00 & 0 & 0,00 & 0 & 0,00 & 0 & 0,00 & 0 & 0,00 & 0 & 0,00 & c & 0 , & & 0 & 0,00 & 0 & 0,00 & 0 & 0,00 & 1 & 1,41 & 0 & 0,00 & 0 & 0,00 & 1 & 1,41 \\
\hline GEM & 0 & 0,00 & 0 & 0,00 & 0 & 0,00 & 2 & 2,82 & 0 & 0,00 & 0 & 0,00 & 0 & 0,00 & 0 & 0,00 & 0 & 0,00 & 0 & 0,00 & c & 0 & & 0 & 0,00 & 0 & 0,00 & 0 & 0,00 & 0 & 0,00 & 0 & 0,00 & 0 & 0,00 & 2 & 2,82 \\
\hline HA & 0 & 0,00 & 0 & 0,00 & 0 & 0,00 & 0 & 0,00 & 0 & 0,00 & 0 & 0,00 & 3 & 4,23 & 0 & 0,00 & 0 & 0,00 & 0 & 0,00 & c & 0, & & 0 & 0,00 & 0 & 0,00 & 0 & 0,00 & 0 & 0,00 & 0 & 0,00 & 0 & 0,00 & 3 & 4,23 \\
\hline PCC & 0 & 0,00 & 0 & 0,00 & 0 & 0,00 & 0 & 0,00 & 0 & 0,00 & 0 & 0,00 & 0 & 0,00 & 0 & 0,00 & 0 & 0,00 & 0 & 0,00 & c & 0, & & 0 & 0,00 & 1 & 1,41 & 0 & 0,00 & 0 & 0,00 & 0 & 0,00 & 0 & 0,00 & 1 & 1,41 \\
\hline $\mathrm{NCC}$ & 0 & 0,00 & 0 & 0,00 & 0 & 0,00 & 0 & 0,00 & 0 & 0,00 & 0 & 0,00 & 0 & 0,00 & 0 & 0,00 & 0 & 0,00 & 1 & 1,41 & 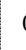 & 0 , & & 0 & 0,00 & 0 & 0,00 & 0 & 0,00 & 0 & 0,00 & 0 & 0,00 & 1 & 1,41 & 2 & 2,82 \\
\hline Distocia & 0 & 0,00 & 0 & 0,00 & 0 & 0,00 & 0 & 0,00 & 0 & 0,00 & 0 & 0,00 & 0 & 0,00 & 3 & 4,23 & 0 & 0,00 & 0 & 0,00 & 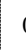 & 0, & & 2 & 2,82 & 0 & 0,00 & 0 & 0,00 & 0 & 0,00 & 0 & 0,00 & 0 & 0,00 & 5 & 7,04 \\
\hline FP & 0 & 0,00 & 0 & 0,00 & 5 & 7,04 & 0 & 0,00 & 0 & 0,00 & 0 & 0,00 & 0 & 0,00 & 0 & 0,00 & 0 & 0,00 & 0 & 0,00 & 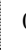 & 0 & & 0 & 0,00 & 0 & 0,00 & 0 & 0,00 & 0 & 0,00 & 0 & 0,00 & 0 & 0,00 & 5 & 7,04 \\
\hline PE & 0 & 0,00 & 0 & 0,00 & 0 & 0,00 & 0 & 0,00 & 0 & 0,00 & 0 & 0,00 & 0 & 0,00 & 0 & 0,00 & 2 & 2,82 & 0 & 0,00 & 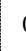 & 0, & & 0 & 0,00 & 0 & 0,00 & 0 & 0,00 & 0 & 0,00 & 0 & 0,00 & 0 & 0,00 & 2 & 2,82 \\
\hline CETGI & 0 & 0,00 & 0 & 0,00 & 0 & 0,00 & 0 & 0,00 & 0 & 0,00 & 0 & 0,00 & 0 & 0,00 & 0 & 0,00 & 0 & 0,00 & 1 & 1,41 & 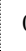 & 0 & & 0 & 0,00 & 0 & 0,00 & 1 & 1,41 & 0 & 0,00 & 0 & 0,00 & 0 & 0,00 & 2 & 2,82 \\
\hline PC & 0 & 0,00 & 0 & 0,00 & 0 & 0,00 & 0 & 0,00 & 0 & 0,00 & 0 & 0,00 & 0 & 0,00 & 0 & 0,00 & 0 & 0,00 & 0 & 0,00 & 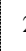 & 2,8 & & 0 & 0,00 & 0 & 0,00 & 0 & 0,00 & 0 & 0,00 & 0 & 0,00 & 0 & 0,00 & 2 & 2,82 \\
\hline Sinusite & 0 & 0,00 & 3 & 4,23 & 0 & 0,00 & 0 & 0,00 & 3 & 4,23 & 0 & 0,00 & 0 & 0,00 & 0 & 0,00 & 0 & 0,00 & 0 & 0,00 & 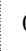 & 0 & & 0 & 0,00 & 0 & 0,00 & 0 & 0,00 & 0 & 0,00 & 0 & 0,00 & 0 & 0,00 & 6 & 8,45 \\
\hline Otite & 0 & 0,00 & 1 & 1,41 & 0 & 0,00 & 0 & 0,00 & 1 & 1,41 & 0 & 0,00 & 0 & 0,00 & 0 & 0,00 & 0 & 0,00 & 0 & 0,00 & 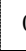 & 0, & & 0 & 0,00 & 0 & 0,00 & 0 & 0,00 & 0 & 0,00 & 0 & 0,00 & 0 & 0,00 & 2 & 2,82 \\
\hline Total & 26 & 36,62 & 7 & 9,86 & 5 & 7,04 & 5 & 7,04 & 5 & 7,04 & 4 & 5,63 & 3 & 4,23 & 3 & 4,23 & 2 & 2,82 & 2 & 2,82 & 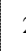 & 2, & & 2 & 2,82 & 1 & 1,41 & 1 & 1,41 & 1 & 1,41 & 1 & 1,41 & 1 & 1,41 & 71 & 100,00 \\
\hline
\end{tabular}

Técnicas operatórias: Ex - exérese; Cm - colheita de material (histopatológico e/ou cultura e antibiograma); Ip - ingluvioplastia; Amp - amputação; Dc - drenagem de cáseo; Bi -

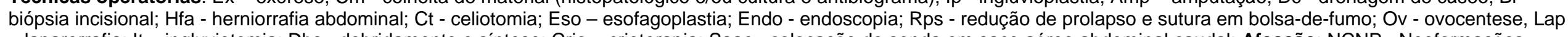

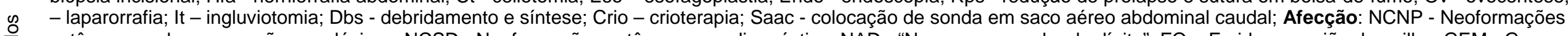

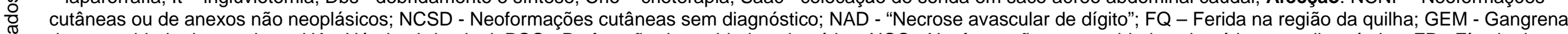

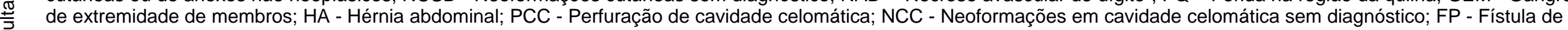
papo; PE - Perfuração de esôfago; CETGI - Corpo estranho em trato gastrointestinal; PC - Prolapso de cloaca 
Para avaliação dos resultados obtidos com as técnicas operatórias empregadas para diagnóstico e/ou tratamento das afecções de tecidos moles foram excluídos 10 casos (APÊNDICE D), devido à falta de dados referentes à evolução pós-operatória registrado nos respectivos prontuários e impossibilidade de sua complementação por contato telefônico com os proprietários.

Os 53 casos avaliados e respectivos resultados obtidos com as técnicas operatórias empregadas para diagnóstico e/ou tratamento das afecções de tecidos moles encontram-se na tabela 17 e imagens de etapas do diagnóstico e/ou tratamento cirúrgico nas figuras 8-12.

A análise dos resultados obtidos no tratamento cirúrgico de 17 neoplasias mostrou que a exérese foi empregada em 14 casos $(82,35 \%, 14 / 17)$, sendo que em um deles a crioterapia esteve associada, quanto ao pós-operatório imediato mostrou-se 100\% (14/14) excelente, ou seja, o tratamento cirúrgico foi curativo; quanto à recidiva e seguimento 78,57\% (11/14) não apresentaram recidiva e 14,28\% (2/14) apresentaram recidiva dentro do período de estudo, enquanto 7,14\% (1/14) ausência desta informação. A biópsia incisional empregada em dois casos $(11,76 \%$, 2/17) quanto ao pós-operatório imediato mostrou-se 100\% (2/2) satisfatória, ou seja, o tratamento cirúrgico não foi curativo, porém possibilitou o diagnóstico; quanto à recidiva e seguimento $100 \%$ (2/2) obitaram. A colheita de material (HP e CATB) empregada em um caso $(5,88 \%, 1 / 17)$ quanto ao pós-operatório imediato mostrouse $100 \%$ (1/1) satisfatória; quanto à recidiva e seguimento $100 \%$ (1/1) foi eutanasiado.

Avaliando os resultados encontrados no tratamento cirúrgico de nove neoformações cutâneas ou de anexos não neoplásicos, a exérese empregada em seis casos $(66,66 \%, 6 / 9)$, associada à colheita de material (CATB) em um caso, quanto ao pós-operatório imediato apresentou-se 83,33\% (5/6) excelente e 16,66\% (1/6) obitaram em até 24 horas da realização do procedimento cirúrgico; quanto à recidiva e seguimento, excluindo-se o caso de óbito já ocorrido, 80\% (4/5) não apresentaram recidiva e 20\% (1/5) ausência desta informação. A biópsia incisional empregada em um caso $(11,11 \%, 1 / 9)$ quanto ao pós-operatório imediato mostrouse $100 \%$ (1/1) satisfatória; quanto à recidiva e seguimento $100 \%$ (1/1) ausência desta informação. A colheita de material (HP e CATB) empregada sozinha em um caso $(11,11 \%, 1 / 9)$ quanto ao pós-operatório imediato mostrou-se $100 \%(1 / 1)$ satisfatória; quanto à recidiva e seguimento 100\% (1/1) ausência desta informação. 
A drenagem de cáseo empregada em um caso $(11,11 \%, 1 / 9)$ quanto ao pósoperatório imediato apresentou 100\% (1/1) de óbito em até 24 horas.

Segundo avaliação dos resultados observados no tratamento cirúrgico de quatro neoformações cutâneas sem diagnóstico, a exérese empregada em dois casos $(50 \%, 2 / 4)$, quanto ao pós-operatório imediato foi 50\% (1/2) excelente, com $50 \%$ (1/2) de óbito em até 24 horas; quanto à recidiva e seguimento, excluindo-se 0 caso de óbito, 100\% (1/1) não apresentaram recidiva. A amputação (25\%, 1/4) e a biópsia incisional $(25 \%, 1 / 4)$, empregadas cada uma em um caso, quanto ao pósoperatório imediato, mostraram ambas 100\% (1/1) de óbito em até 24 horas.

Os resultados obtidos para as cinco distocias tratadas cirurgicamente revelaram que a celiotomia empregada em três casos $(60 \%, 3 / 5)$, quanto ao pósoperatório imediato mostrou-se 33,33\% (1/3) excelente com 66,66\% (2/3) de óbito em até 24 horas; quanto à recidiva e seguimento, excluindo-se os casos de óbito já ocorridos, 100\% (1/1) não apresentaram recidiva. A ovocentese empregada em dois casos $(40 \%, 2 / 5)$, uma realizada via transcutânea abdominal e a outra via cloacal, quanto ao pós-operatório imediato apresentou-se 100\% (2/2) excelente; quanto à recidiva e seguimento 50\% (1/2) não mostraram recidiva e 50\% (1/2) ausência desta informação.

Segundo análise dos resultados obtidos no tratamento cirúrgico de quatro fístulas de papo, a ingluvioplastia, única técnica operatória empregada (100\%, 4/4), quanto ao pós-operatório imediato mostrou-se 75\% (3/4) excelente, com 25\% (1/4) de óbito em até 24 horas; quanto à recidiva e seguimento, excluindo-se o caso de óbito já ocorrido, 100\% (3/3) não apresentaram recidiva.

A herniorrafia abdominal (100\%, 2/2), técnica operatória empregada em dois casos de hérnia abdominal, quanto ao pós-operatório imediato foi $100 \%(2 / 2)$ excelente e quanto à recidiva e seguimento 100\% (2/2) não apresentaram recidiva.

A esofagoplastia $(100 \%, 2 / 2)$, empregada nos dois casos de perfuração de esôfago, mostrou-se quanto ao pós-operatório imediato 50\% (1/2) excelente, com $50 \%(1 / 2)$ de óbito em até 24 horas; quanto à recidiva e seguimento, excluindo-se o caso de óbito já ocorrido, 100\% (1/1) não apresentaram recidiva.

A redução de prolapso e sutura em bolsa-de-fumo (100\%, 2/2), empregada nos dois casos de prolapso de cloaca, quanto ao pós-operatório imediato foi $50 \%$ 
(1/2) excelente e 50\% (1/2) obitaram até 24 horas; quanto à recidiva e seguimento, excluindo-se o caso de óbito já ocorrido, 100\% (1/1) não apresentaram recidiva.

A drenagem de cáseo associada à colheita de material (CATB) (100\%, 2/2), técnicas operatórias empregadas em dois casos de sinusite, quanto ao pósoperatório imediato mostraram 100\% (2/2) excelente e quanto à recidiva e seguimento 50\% (1/2) não apresentaram recidiva e 50\% (1/2) ausência desta informação.

Tanto a laparorrafia $(100 \%, 1 / 1)$, empregada para o único caso de perfuração de cavidade celomática, como a colocação de sonda em saco aéreo abdominal caudal associada à endoscopia $(100 \%, 1 / 1)$, empregada para o único caso de neoformação em cavidade celomática sem diagnóstico, quanto ao pós-operatório imediato, resultaram em 100\% (1/1) de óbito em até 24 horas.

A ingluviotomia associada à endoscopia (100\%, 1/1), técnicas operatórias empregadas para o único caso de CE em trato gastrointestinal, quanto ao pósoperatório imediato mostraram-se 100\% (1/1) excelente e quanto à recidiva e seguimento 100\% (1/1) não apresentaram recidiva.

O debridamento e síntese $(100 \%, 1 / 1)$, empregado para o único caso de ferida na região da quilha, quanto ao pós-operatório imediato foi $100 \%$ (1/1) excelente e quanto à recidiva e seguimento $100 \%$ (1/1) não apresentaram recidiva.

A amputação $(100 \%, 2 / 2)$, técnica operatória empregada para o único caso de "Necrose avascular de dígito" e para um caso de gangrena de extremidade de membro, mostrou-se quanto ao pós-operatório imediato 100\% (2/2) excelente e quanto à recidiva e seguimento 100\% (2/2) não apresentaram recidiva. 
Tabela 17 - Distribuição dos 53 casos avaliados quanto aos resultados obtidos com as técnicas operatórias para afecções de tecidos moles utilizadas nas aves São Paulo - janeiro de 2000 a junho de 2008

\begin{tabular}{|c|c|c|c|c|c|c|c|c|c|c|c|c|c|}
\hline \multirow{2}{*}{$\begin{array}{l}N^{\circ} \text { do } \\
\text { caso }\end{array}$} & \multirow{2}{*}{$\begin{array}{l}\text { Nome comum } \\
\text { (Nome científico) }\end{array}$} & \multirow{2}{*}{$\begin{array}{l}\text { Afecção de tecidos moles } \\
\text { (diagnóstico final) }\end{array}$} & \multirow{2}{*}{$\begin{array}{l}\text { Técnica } \\
\text { operatória }\end{array}$} & \multicolumn{5}{|c|}{ Pós-operatório imediato } & \multicolumn{5}{|c|}{ Recidiva e seguimento } \\
\hline & & & & SI & $\mathbf{E}$ & $\mathbf{s}$ & $\mathbf{I}$ & Obi* & Não & Sim & Obi & SI & Eut \\
\hline 1 & Pato-doméstico (Cairina moschata) & Hérnia abdominal & $\mathrm{Hfa}$ & & $x$ & & & & $x$ & & & & \\
\hline 2 & Papagaio-verdadeiro (Amazona aestiva) & Lipoma pericloacal & Ex & & $x$ & & & & $x$ & & & & \\
\hline 3 & Papagaio-verdadeiro (Amazona aestiva) & $\begin{array}{l}\text { Hemangiossarcoma bem diferenciado } \\
\text { em MP }\end{array}$ & Ex & & $x$ & & & & $\mathrm{x}$ & & & & \\
\hline 6 & Papagaio-verdadeiro (Amazona aestiva) & Fístula de papo recidivante & Ip & & $\mathrm{x}$ & & & & $\mathrm{x}$ & & & & \\
\hline 7 & Papagaio-verdadeiro (Amazona aestiva) & Distocia (ovo retido) & Ovo (cloaca) & & $x$ & & & & $x$ & & & & \\
\hline 8 & Papagaio-verdadeiro (Amazona aestiva) & Hérnia abdominal & $\mathrm{Hfa}$ & & $x$ & & & & $x$ & & & & \\
\hline 9 & Arara-canindé (Ara ararauna) & Melanoma mandibular & $\mathrm{Bi}$ & & & $x$ & & & & & $x$ & & \\
\hline 10 & $\begin{array}{l}\text { Periquito-australiano (Melopsittacus } \\
\text { undulatus) }\end{array}$ & $\begin{array}{l}\text { Neoformação cutânea em asa sem } \\
\text { diagnóstico }\end{array}$ & Amp & & & & & $\mathrm{x}$ & & & $\mathrm{x}$ & & \\
\hline 11 & Curica, papagaio (Amazona amazonica) & Lipoma pericloacal & Ex & & $x$ & & & & & $x$ & & & \\
\hline 12 & Curica, papagaio (Amazona amazonica) & Lipoma pericloacal & Ex & & $x$ & & & & & $x$ & & & \\
\hline 13 & Curica, papagaio (Amazona amazonica) & Lipoma pericloacal & Ex & & $\mathrm{x}$ & & & & $x$ & & & & \\
\hline 15 & Papagaio-verdadeiro (Amazona aestiva) & Cáseo submandibular & Ex & & $x$ & & & & $\mathrm{x}$ & & & & \\
\hline 16 & Papagaio-verdadeiro (Amazona aestiva) & $\begin{array}{l}\text { Perfuração cavidade celomática e } \\
\text { peritonite }\end{array}$ & Lap & & & & & $x$ & & & $x$ & & \\
\hline 17 & Papagaio-verdadeiro (Amazona aestiva) & Prolapso de cloaca & Rps & & $x$ & & & & $x$ & & & & \\
\hline 18 & $\begin{array}{l}\text { Papagaio-de-cara-roxa (Amazona } \\
\text { brasiliensis*) }\end{array}$ & Sinusite & Dc; C m (CATB) & & $x$ & & & & $x$ & & & & \\
\hline 19 & Papagaio-verdadeiro (Amazona aestiva) & $\begin{array}{l}\text { Neoformação em cavidade celomática } \\
\text { sem diagnóstico }\end{array}$ & Saac; Endo & & & & & $x$ & & & $x$ & & \\
\hline 20 & Arara-canindé (Ara ararauna) & Fístula por CE em esôfago cervical & Eso & & & & & $x$ & & & $x$ & & \\
\hline 21 & Papagaio-verdadeiro (Amazona aestiva) & Cáseo cervical & $\mathrm{Ex} ; \mathrm{Cm}(\mathrm{CATB})$ & & $x$ & & & & $x$ & & & & $\begin{array}{l}4 \\
0 \\
0 \\
0 \\
0^{\circ} \\
\frac{1}{5} \\
\frac{n}{\delta} \\
\delta\end{array}$ \\
\hline
\end{tabular}




\begin{tabular}{|c|c|c|c|c|c|c|c|c|c|c|c|c|c|}
\hline \multirow{2}{*}{$\begin{array}{l}\mathrm{N}^{\circ} \text { do } \\
\text { caso }\end{array}$} & \multirow{2}{*}{$\begin{array}{l}\text { Nome comum } \\
\text { (Nome científico) }\end{array}$} & \multirow{2}{*}{$\begin{array}{l}\text { Afecção de tecidos moles } \\
\text { (diagnóstico final) }\end{array}$} & \multirow{2}{*}{$\begin{array}{l}\text { Técnica } \\
\text { operatória }\end{array}$} & \multicolumn{5}{|c|}{ Pós-operatório imediato } & \multicolumn{5}{|c|}{ Recidiva e seguimento } \\
\hline & & & & SI & $\mathbf{E}$ & $\mathbf{S}$ & $\mathbf{I}$ & Obi* $^{*}$ & Não & Sim & Obi & SI & Eut \\
\hline 22 & Papagaio-verdadeiro (Amazona aestiva) & Cáseo peitoral & Ex & & & & & $x$ & & & $x$ & & \\
\hline 23 & Papagaio-verdadeiro (Amazona aestiva) & Ferida traumática em quilha & Dbs & & $x$ & & & & $\mathrm{x}$ & & & & \\
\hline 25 & Papagaio-verdadeiro (Amazona aestiva) & Lipossarcoma pericloacal & Ex & & $x$ & & & & $x$ & & & & \\
\hline 26 & Curica, papagaio (Amazona amazonica) & Lipoma abdominal e pericloacal & Ex & & $x$ & & & & $x$ & & & & \\
\hline 27 & Curica, papagaio (Amazona amazonica) & Lipoma pericloacal & Ex & & $x$ & & & & $\mathrm{x}$ & & & & \\
\hline 28 & Papagaio (Amazona sp.) & Neoformação cutânea sem diagnóstico & Ex & & $\mathrm{x}$ & & & & $x$ & & & & \\
\hline 29 & Papagaio-verdadeiro (Amazona aestiva) & Lipoma abdominal ventral & Ex & & $x$ & & & & $\mathrm{x}$ & & & & \\
\hline 30 & $\begin{array}{l}\text { Papagaio-campeiro (Amazona } \\
\text { ochrocephala) }\end{array}$ & Neoformação cutânea sem diagnóstico & $\mathrm{Bi}$ & & & & & $x$ & & & $x$ & & \\
\hline 31 & Papagaio-verdadeiro (Amazona aestiva) & Cisto infundibular ("cisto de pena") & $\mathrm{Bi}$ & & & $x$ & & & & & & $x$ & \\
\hline 33 & Curica, papagaio (Amazona amazonica) & Cáseo cavidade oral & $\mathrm{Dc}$ & & & & & $x$ & & & $x$ & & \\
\hline 34 & Papagaio (Amazona sp.) & Sinusite & Dc; Cm (CATB) & & $x$ & & & & & & & $x$ & \\
\hline 35 & Anacã (Deroptyus accipitrinus) & Fístula de papo recidivante & Ip & & & & & $x$ & & & $x$ & & \\
\hline 36 & Maracanã-pequena (Diopsittaca nobilis) & Carcinoma oral de células escamosas & $\mathrm{Cm}(\mathrm{HP}, \mathrm{CATB})$ & & & $\mathrm{x}$ & & & & & & & $\mathrm{x}$ \\
\hline 37 & Pombo-doméstico (Columba livia) & Distocia (ovo retido) & $\mathrm{Ct}$ & & & & & $\mathrm{x}$ & & & $x$ & & \\
\hline 38 & Papagaio (Amazona sp.) & Distocia (ovo retido) & $\mathrm{Ct}$ & & $x$ & & & & $\mathrm{x}$ & & & & \\
\hline 39 & Papagaio-verdadeiro (Amazona aestiva) & Prolapso de cloaca & Rps & & & & & $\mathrm{x}$ & & & $\mathrm{x}$ & & \\
\hline 40 & Pombo-doméstico (Columba livia) & Perfuração esôfago cervical & Eso & & $x$ & & & & $x$ & & & & \\
\hline 41 & Papagaio-verdadeiro (Amazona aestiva) & Cáseo cervical & Ex & & $x$ & & & & $\mathrm{x}$ & & & & \\
\hline
\end{tabular}


(Conclusão)

\begin{tabular}{|c|c|c|c|c|c|c|c|c|c|c|c|c|c|}
\hline \multirow{2}{*}{$\begin{array}{l}N^{\circ} \text { do } \\
\text { caso }\end{array}$} & \multirow{2}{*}{$\begin{array}{l}\text { Nome comum } \\
\text { (Nome científico) }\end{array}$} & \multirow{2}{*}{$\begin{array}{l}\text { Afecção de tecidos moles } \\
\text { (diagnóstico final) }\end{array}$} & \multirow{2}{*}{$\begin{array}{l}\text { Técnica } \\
\text { operatória }\end{array}$} & \multicolumn{5}{|c|}{ Pós-operatório imediato } & \multicolumn{5}{|c|}{ Recidiva e seguimento } \\
\hline & & & & SI & $\mathbf{E}$ & $\mathbf{S}$ & $\mathbf{I}$ & Obi* & Não & Sim & Obi & SI & Eut \\
\hline 43 & Papagaio-verdadeiro (Amazona aestiva) & Cisto infundibular ("cisto de pena") & Ex & & $x$ & & & & $x$ & & & & \\
\hline 44 & Papagaio-verdadeiro (Amazona aestiva) & $\begin{array}{l}\text { Corpo estranho (tubo p/alimentação) em } \\
\text { proventrículo e ventrículo }\end{array}$ & $\begin{array}{l}\text { Endo } \\
\text { It }\end{array}$ & & $x$ & & & & $x$ & & & & \\
\hline 45 & Papagaio-verdadeiro (Amazona aestiva) & Fístula de papo & Ip & & $x$ & & & & $x$ & & & & \\
\hline 46 & Papagaio (Amazona sp.) & Fístula de papo recidivante & Ip & & $\mathrm{x}$ & & & & $x$ & & & & \\
\hline 47 & Papagaio-verdadeiro (Amazona aestiva) & Tuberculose & $\mathrm{Cm}$ (HP, CATB) & & & $x$ & & & & & & $x$ & \\
\hline 48 & $\begin{array}{l}\text { Periquito-australiano (Melopsittacus } \\
\text { undulatus) }\end{array}$ & Gangrena extremidade membro pélvico & Amp & & $x$ & & & & $x$ & & & & \\
\hline 51 & Canário-do-reino (Serinus canaria) & Distocia (ovo retido) & Ovo (tca) & & $x$ & & & & & & & $x$ & \\
\hline 52 & Canário-do-reino (Serinus canaria) & Distocia (ovoperitonite) & $\mathrm{Ct}$ & & & & & $x$ & & & $x$ & & \\
\hline 53 & Papagaio (Amazona sp.) & Lipoma membro pélvico e pericloacal & Ex & & $x$ & & & & $x$ & & & & \\
\hline 56 & Papagaio-verdadeiro (Amazona aestiva) & Lipoma pericloacal & Ex & & $x$ & & & & $x$ & & & & \\
\hline 57 & Arara-canindé (Ara ararauna) & Dermatite hiperplásica crônica de dígito & Amp & & $\mathrm{x}$ & & & & $x$ & & & & \\
\hline 59 & Papagaio (Amazona sp.) & Linfoma & $\mathrm{Bi}$ & & & $x$ & & & & & $x$ & & \\
\hline 60 & Rosela (Platycercus eximius) & Lipoma pericloacal & Ex & & $x$ & & & & & & & $x$ & \\
\hline 62 & Papagaio (Amazona sp.) & Lipoma em dorso & $\begin{array}{l}\text { Ex } \\
\text { Crio }\end{array}$ & & $x$ & & & & $x$ & & & & \\
\hline 63 & Calopsita (Nymphicus hollandicus) & Neoformação cutânea sem diagnóstico & Ex & & & & & $x$ & & & $x$ & & \\
\hline \multicolumn{4}{|c|}{ Total } & 0 & 36 & 5 & 0 & 12 & 30 & 2 & 14 & 6 & 1 \\
\hline
\end{tabular}

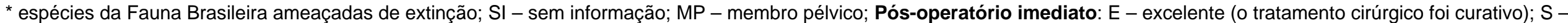
satisfatório (o tratamento cirúrgico não foi curativo, porém possibilitou o diagnóstico), I - insatisfatório (o tratamento cirúrgico piorou a condição clínica do paciente); Obi* - óbito (o paciente obitou até 24 horas da realização do procedimento cirúrgico); Recidiva e seguimento: Não - o paciente não apresentou recidiva dentro do período do estudo; Sim - o

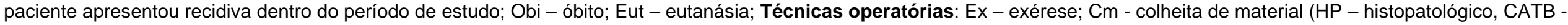

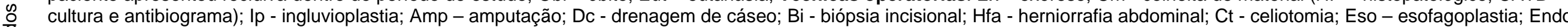

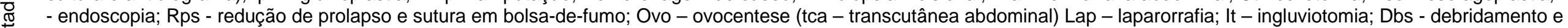
síntese; Crio - crioterapia; Saac - colocação de sonda em saco aéreo abdominal cauda 

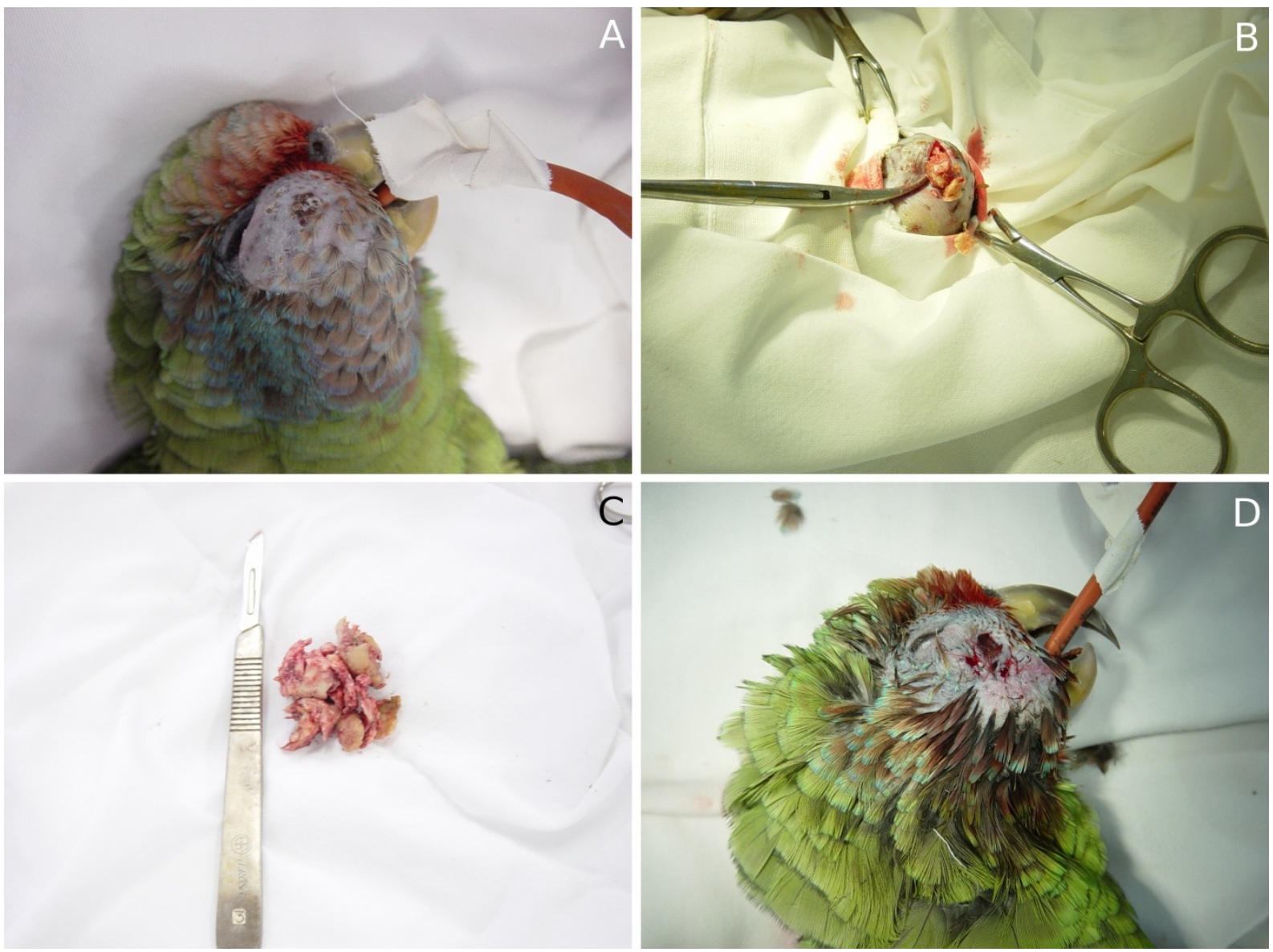

Foto: CASTRO, P. F. (2010)

Figura 8 - Sinusite em papagaio-de-cara-roxa (Amazona brasiliensis*). (A) Pré-operatório imediato: distensão de seio nasal direito. (B) Trans-operatório: ferida cirúrgica para acesso ao seio nasal com visualização de material caseoso. (C) Detalhe do material caseoso drenado. (D) Pós-operatório imediato: ferida cirúrgica limpa (Caso n 18$)$

* espécie da Fauna Brasileira ameaçada de extinção
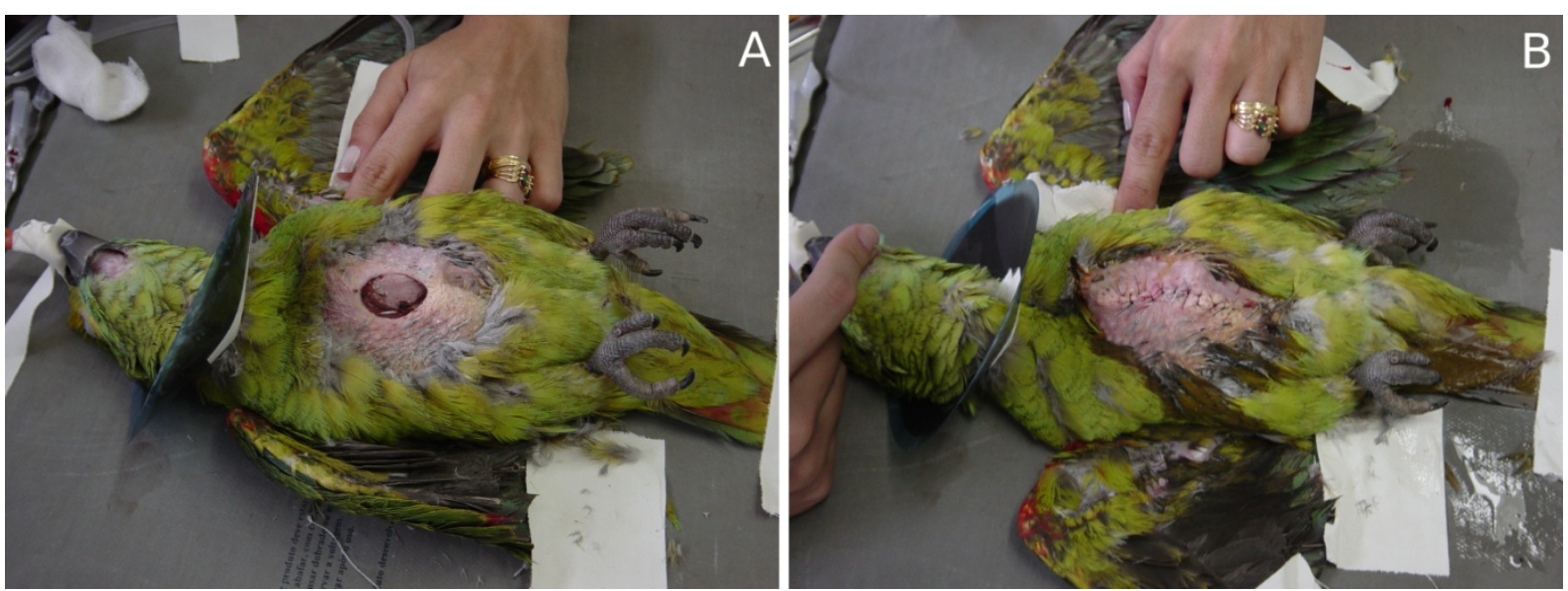

Foto: CASTRO, P. F. (2010)

Figura 9 - Ferida traumática na região da quilha em papagaio-verdadeiro (Amazona aestiva). (A) Pré-operatório imediato: ferida tricotomizada. (B) Pós-operatório imediato: síntese cutânea padrão ponto-simples-separado com náilon 5-0 (Caso nº 23) 


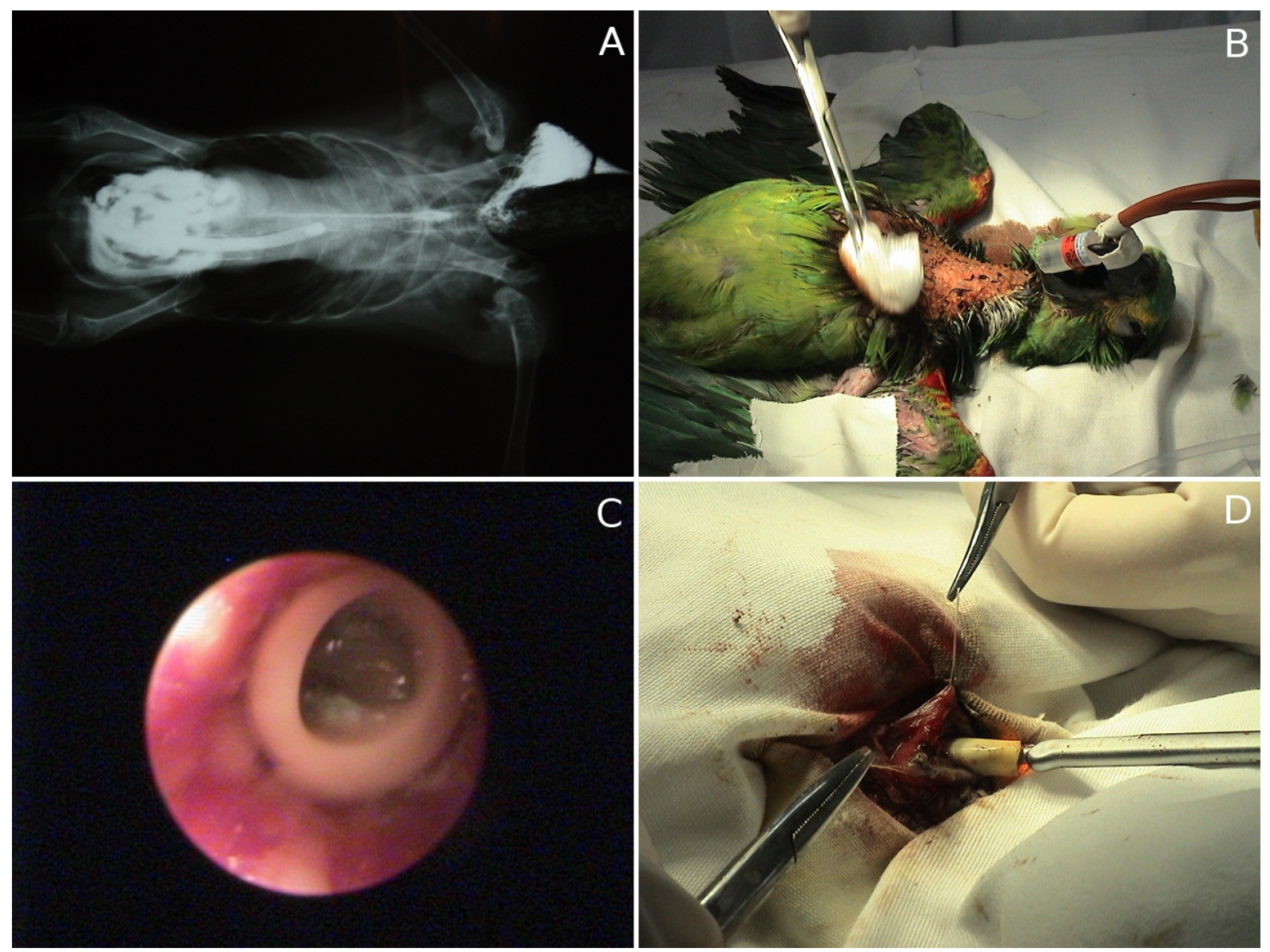

Foto: CASTRO, P. F. (2010)

Figura 10 - CE em trato gastrointestinal de papagaio-verdadeiro (Amazona aestiva). (A) Imagem radiográfica em projeção ventro-dorsal do trânsito gastrointestinal na qual nota-se a presença de estrutura tubular em proventrículo e ventrículo. (B) Pré-operatório imediato: região do papo preparada para ingluviotomia. (C) Endoscopia: visualização do CE (sonda de alimentação) em proventrículo. (D) CE sendo retirado pelo inglúvio após sua apreensão com pinça de endoscopia (Caso $\left.n^{\circ} 44\right)$ 


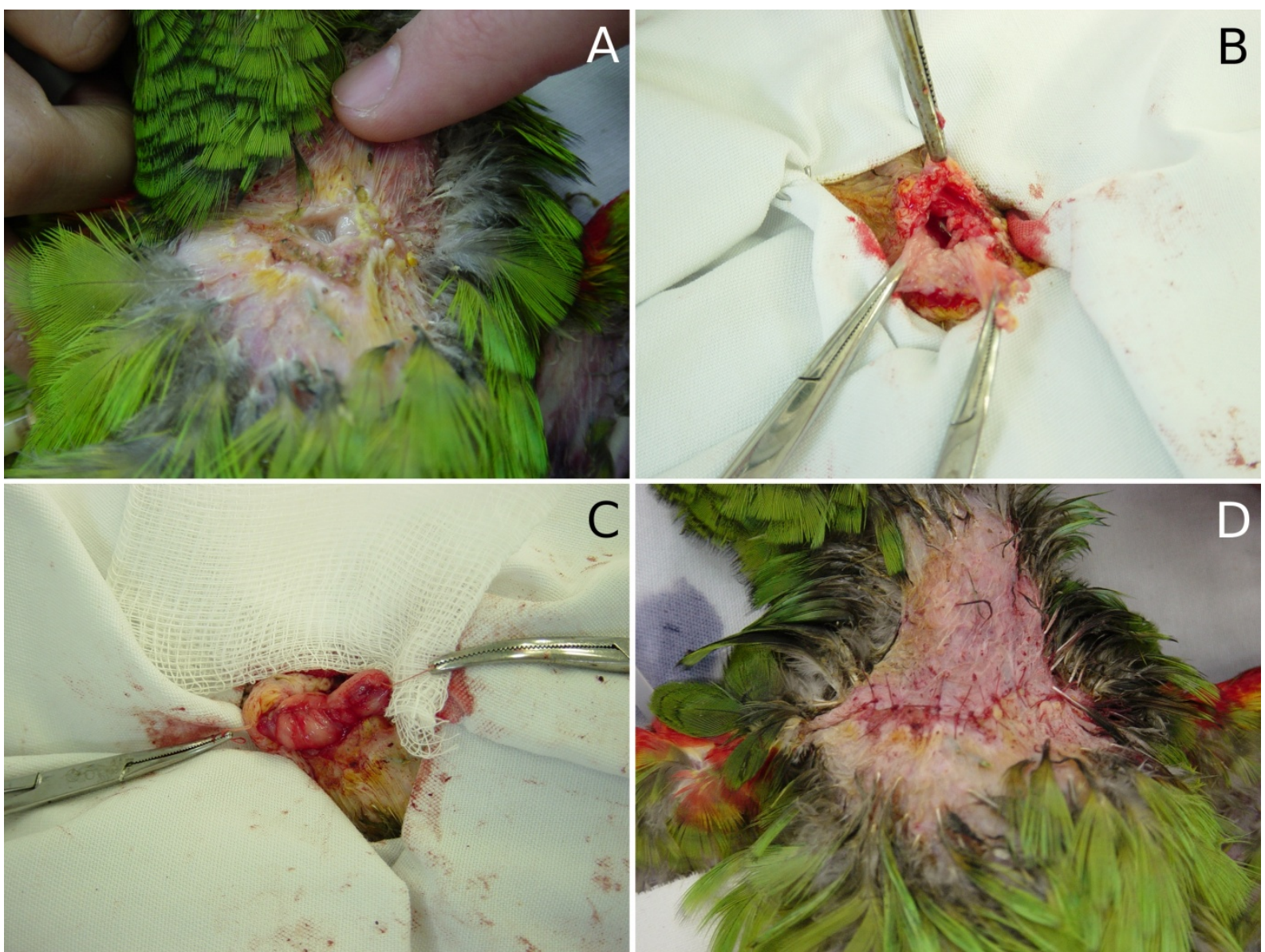

Foto: CASTRO, P. F. (2010)

Figura 11 - Fístula de papo em papagaio-verdadeiro (Amazona aestiva). (A) Fístula inglúvio-cutânea cujas bordas encontram-se parcialmente cobertas por resíduo alimentar. (B) Transoperatório: incisão das bordas da fístula com separação de pele e inglúvio. (C) Transoperatório: inglúvio suturado em padrão invertido Cushing camada única com fio poliglactina 910 5-0. (D) Pós-operatório imediato: síntese cutânea padrão ponto-simplesseparado (Caso $\left.\mathrm{n}^{\circ} 45\right)$ 


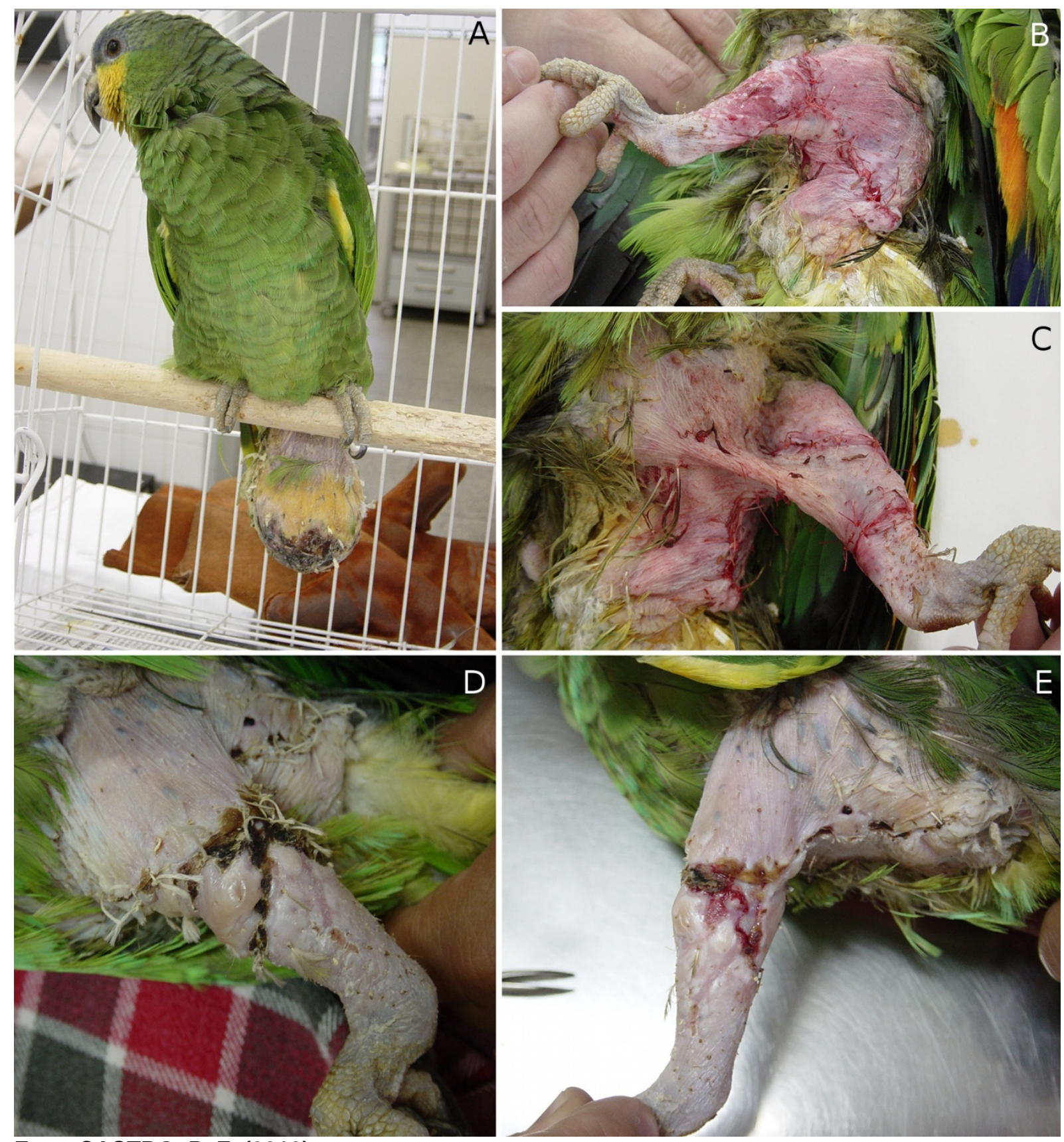

Foto: CASTRO, P. F. (2010)

Figura 12 - Lipoma em membro pélvico e pericloacal em papagaio (Amazona sp.). (A) Paciente com neoformação ulcerada e de aspecto pendular em região caudal. (B) Pós-operatório imediato: síntese cutânea padrão ponto-simples-separado com fio poliglactina 910 4-0 em face lateral e (C) em face medial de membro pélvico e pericloacal. (D) Síntese e (E) cicatrização cutânea após a retirada dos pontos, aos 15 dias de pós-operatório (Caso n ${ }^{\circ}$ 53) 

DISCUSSÃO 



\section{DISCUSSÃO}

Helmer e Redig (2006) afirmam que as injúrias ortopédicas são freqüentes na clínica de pássaros de companhia, enquanto Bennett e Harrison (1994) ressaltam que operações em tecidos moles realizadas em aves aumentaram substancialmente na última década. De fato, a introdução do isofluorano como agente anestésico para aves em 1985, por Greg Harrison, propiciou à classe de cirurgiões veterinários a possibilidade de realizar intervenções cirúrgicas até então inexeqüíveis nesta classe de animais (ALTMAN, 1998), contudo, limitações para operações abdominais em espécies muito pequenas ou operações torácicas continuam difíceis de serem superadas (BENNETT; HARRISON, 1994). Neste estudo, o grupo de afecções ortopédicas respondeu por 30\% (27/90) e o de afecções de tecidos moles por $70 \%$ (63/90) das operações realizadas para diagnóstico e/ou tratamento de aves; afecções que necessitaram de cirurgias abdominais (hérnia abdominal, perfuração de cavidade celomática, neoformação em cavidade celomática sem diagnóstico, distocia e CE em trato gastrointestinal) corresponderam a apenas 17,47\% (11/63) das afecções de tecidos moles e não houve registro de afecções cirúrgicas torácicas, dados que validam o que foi encontrado na literatura.

Outro fator que pode ter contribuído para o número de afecções cirúrgicas de tecidos moles ter superado o de afecções ortopédicas em 2,33 vezes, foi o elevado número de casos de neoplasias, reafirmando Schmidt e Quesenberry (1997) e Reavill (2004). Hipoteticamente, se somarmos aos casos de neoplasias $(21,11 \%$, 19/90) àqueles com "potencial neoplásico", classificados como neoformações cutâneas sem diagnóstico (5/90) e neoformação em cavidade celomática sem diagnóstico (1/90), tal soma representaria 27,77\% (25/90) do total de casos operados, e se equipararia às afecções cirúrgicas ortopédicas (30\%, 27/90).

Dentre as ordens de aves de companhia listadas por Burr (1987), as únicas que não ocorreram em nosso estudo foram Galliformes e Strigiformes, em contrapartida, além das ordens Psittaciformes e Passeriformes, citadas por Forbes e Lawton (1996), as ordens Anseriformes, Columbiformes, Piciformes e Falconiformes também foram observadas. A ocorrência e popularidade distintas das aves nas diversas regiões do mundo justificam parcialmente tais achados e reafirmam a 
importância de estudos desenvolvidos em nosso meio para a identificação das aves usualmente mantidas como animais de estimação, assim como a identificação dos exemplares da fauna local que possam necessitar de atendimento clínico-cirúrgico.

A prevalência da ordem Psittaciformes quanto ao número de aves operadas $(89,66 \%, 78 / 87)$, de afecções cirúrgicas ortopédicas $(85,19 \%, 23 / 27)$ e de tecidos moles (92,06\%, 58/63) - em semelhança aos 82\% observado por Sinhorini (2008) em estudo com neoplasias e superando os 68,09\% observado por Arnaut (2006) em estudo radiográfico, ambos conduzidos em nosso meio; excedendo os achados da casuística de aves atendidas na Bahia por Gondim, Gomes e Maia (2006) cuja prevalência foi $59,31 \%$, bem como o valor de $43,48 \%$ encontrado por Santos et al. (2008) no Paraná, que correspondeu às maiores ocorrências das doenças de aves justifica-se, visto que o Brasil possui o maior número de espécies de psitacídeos do planeta (GILL, 1995; GALETTI; PIZO, 2002), confirma que o grupo dos psitacídeos, inteligentes e hábeis em imitar sons humanos (FORBES; LAWTON, 1996), é um dos mais procurados como animal de estimação em nosso meio (SICK, 1997), e sugere serem estas as causas para o predomínio da ordem Psittaciformes neste e nos estudos nacionais acima relacionados.

Arnaut (2006); Sinhorini (2008) e Santos et al. (2008) encontraram a ordem Passeriformes - considerada por alguns autores como a mais popular (CUBAS; GODOY, 2007) por contemplar aves de companhia muito reproduzidas no Brasil pelo seu alto valor comercial (GUIMARÃES, 2007) - como a segunda em prevalência, representadas respectivamente por 11,70\%, 15\% e 26,88\%. A diferença quanto à freqüência de ocorrência desta ordem, que em nosso estudo foi 2,30\% (2/87), deve-se, provavelmente, ao perfil das aves segundo o tipo de estudo realizado, visto que os passeriformes encontram-se representadas, em geral, por espécimes de pequeno porte, portanto com alto grau de morbidade e mortalidade cirúrgica (HELMER; REDIG, 2006) e, por esta razão, compõem um grupo com restrição à realização de operações. De fato, o canário-do-reino (Serinus canaria), que pesa de 12 a 30 gramas (GUIMARÃES, 2007), foi a única espécie da ordem Passeriformes operada, representada por apenas dois exemplares, enquanto para Gondim, Gomes e Maia (2006) os canários responderam por 17,24\% do total de consultas a aves.

As informações para a classificação taxonômica das aves permitiram identificar $74,71 \%$ do total de aves operadas quanto à espécie, dentre as quais um 
papagaio-de-cara-roxa (Amazona brasiliensis), um papagaio-de-peito-roxo (Amazona vinacea) e uma arara-azul-grande (Anodorhynchus hyacinthinus) constam da Lista das Espécies da Fauna Brasileira Ameaçadas de Extinção do Ministério do Meio Ambiente (BRASIL, 2003a; b). Para os 25,29\% restantes, as informações sobre a espécie eram inexistentes, portanto os exemplares foram abordados segundo o gênero, como ocorreu para os papagaios designados Amazona sp, para os periquitos-verde designados Brotogeris sp. e para um cisne designado Cygnus sp.

Enquanto Dilger (1982) considera o periquito-australiano (Melopsittacus undulatus) a ave de gaiola mais popular mantida como "pet", os estudos nacionais de casuística de aves não restritos a afecções específicas, como os de Gondim, Gomes e Maia (2006) e os de Santos et al. (2008) encontraram, respectivamente, os papagaios e o canário (Serinus canaria) como as espécies de maior ocorrência. Em nosso estudo que abordou exclusivamente afecções cirúrgicas, o papagaioverdadeiro (Amazona aestiva) foi a espécie de maior ocorrência (34,48\%, 30/87) e não foram encontrados estudos nacionais similares para efeito de comparação.

Ainda, este estudo mostrou grande disparidade entre a freqüência de ocorrência de exemplares psitaciformes operados pertencentes ao prevalente "grupo dos papagaios" $(67,82 \%, 59 / 87)$ em relação às demais espécies. Este grupo superou em 11,8 vezes a segunda espécie mais freqüente, que foi a arara-canindé (Ara ararauna) e em 14,75 vezes a terceira que foi o periquito-australiano (Melopsittacus undulatus). É fato que o Brasil possui o maior número de espécies de psitacídeos do planeta (GILL, 1995; GALETTI; PIZO, 2002) e criar aves no Brasil é costume recente em comparação a outros países (SINHORINI, 2008), o que nos faz suspeitar, apesar de não ter sido objeto deste estudo, que a maioria das aves pertencentes ao "grupo dos papagaios" tenha sido capturada da natureza e comercializada ilegalmente, como observado por Fotin (2005) em São Paulo e constatado por Gondim, Gomes e Maia (2006) na Bahia, onde 100\% das aves nativas atendidas foram adquiridas através do comércio ilegal.

Um papagaio-verdadeiro (Amazona aestiva) foi submetido a duas intervenções cirúrgicas para exérese de neoplasias diversas (lipoma e hemangiossarcoma bem diferenciado), e um curica (Amazona amazonica) a três exéreses de neoplasia de mesma origem (lipoma), por apresentar duas vezes recidiva no sítio operado, dados 
que justificam a diferença entre o número total de aves operadas ( $n=87)$ e o total de operações realizadas $(n=90)$.

A variável sexo não foi considerada, pois o dimorfismo sexual nem sempre aparece dentro da classe aviária, fazendo-se necessárias técnicas para determinar o sexo (SICK, 1997) não utilizadas. A falta ou imprecisão de informação quanto à idade, por parte dos proprietários, não permitiu a análise desta variável.

Por tratar-se de estudo retrospectivo, diversas foram as técnicas operatórias utilizadas bem como o tipo de resultado obtido no pós-operatório, portanto, para facilitar a interpretação destes resultados e avaliar as técnicas operatórias, os dados colhidos foram reunidos e classificados segundo critérios próprios adotados para cada um dos grupos: avaliação radiográfica (consolidação/eixo ósseo) e retorno à função para o grupo Ortopedia e pós-operatório imediato e recidiva/seguimento para o grupo Tecidos Moles. Para ambos os grupos, o número de casos avaliados foi menor que o de casos operados, em virtude da exclusão de casos segundo critérios mencionados na metodologia.

\subsection{ORTOPEDIA}

Helmer e Redig (2006) atribuem etiologia traumática à maioria das afecções ortopédicas que ocorrem nas aves, fato comprovado por diversos autores que encontraram tais afecções como as mais freqüentemente observadas, com prevalências que variaram de 22,13\% (SANTOS et al., 2008), 23,45\% (GONDIM; GOMES; MAIA, 2006) e 46,77\% (ARNAUT, 2006), o que corrobora com os achados deste estudo, no qual todas as afecções cirúrgicas ortopédicas (30\%, 27/90) constituíram-se afecções traumáticas, exceto por um único caso de artrite e osteomielite bacteriana, cuja origem permaneceu desconhecida, e, portanto passível de ser atribuída a ferida por trauma ou a via hematógena, como sugerido por Quesenberry, Orosz e Dorrestein (1997).

As injúrias traumáticas estão entre as afecções mais encontradas pelos veterinários cirurgiões que trabalham com psitacídeos (SIMPSON, 1996) e a redução de fraturas é uma das intervenções cirúrgicas mais freqüentes para este grupo (GODOY, 2007). De fato, os achados deste estudo mostraram ocorrência de 
100\% (23/23) de afecções cirúrgicas ortopédicas traumáticas, das quais 91,30\% (21/23) fraturas, que acometeram a ordem Psittaciformes.

O predomínio das fraturas sobre as demais afecções ortopédicas encontrado na literatura (MCCARTNEY, 1994; ARNAUT, 2006; SANTOS et al., 2008) e confirmado por este estudo $(88,89 \%, 24 / 27)$, justifica-se, visto que as corticais ósseas finas e frágeis das aves tendem a fragmentar-se quando submetidas à força imposta sobre elas (BLASS, 1987; LEVITT, 1989; KAVANAGH, 1997) e há pouco tecido mole cobrindo os ossos para protegê-los (HELMER; REDIG, 2006). Em contrapartida, luxações apresentam baixa ocorrência (MCCARTNEY, 1994; SOUZA; FIELDS; DEGERNES, 2004; SANTOS et al., 2008) sendo raras as luxações de joelho (ROSENTHAL; HILLYER; MATHIESSEN, 1994; BENNETT, 1997), representadas por apenas um caso $(3,7 \%, 1 / 27)$ ocorrido em um papagaio (Amazona amazonica). Nas aves as luxações são menos comuns que as fraturas devido à característica pneumática dos ossos e de seus ligamentos bem desenvolvidos. Forças aplicadas na área do joelho quase sempre produzirão fratura ao invés de luxação (BLASS, 1987).

A ocorrência de fraturas que superou em 24 vezes as demais afecções (luxação, avulsão de extremidade e artrite/osteomielite) aproximou-se daquela encontrada por McCartney (1994) de 70,3\% e Arnaut (2006) de 74,47\%, cujos estudos abordaram alterações ortopédicas e as fraturas mostraram-se prevalentes, e representou mais que o dobro daquela observada por Redig (1986) de $34 \%$ e Santos et al. (2008) de 30,91\%, em seus levantamentos de atendimentos gerais realizados, tendo se mostrado também prevalente neste último. Credita-se à amostra estudada ser exclusivamente composta por aves portadoras de afecções ortopédicas submetidas a tratamento cirúrgico, a superioridade do percentual de fraturas observado $(88,89 \%)$ em relação aos autores supracitados.

A proporção na qual ocorrem fraturas de membros torácicos e pélvicos em aves diverge na literatura. Para a grande maioria dos autores, as fraturas de asa são mais frequentes que as de perna (REDIG, 1986; HOWARD, 1990; KUZMA; HUNTER, 1991; MACCARTNEY, 1994; BENNETT, 1997; SOUZA; FIELDS; DEGERNES, 2004). Para McCartney (1994), que estudou exclusivamente pombos oriundos da vida livre, a justificativa encontra-se no fato das injúrias ocorrerem com maior freqüência durante o vôo e por aves com fraturas de perna, menos incapacitantes, receberem menos socorro. Ao contrário, para Blass (1987) e Arnaut 
(2006), e como observado em nosso estudo, as fraturas de membro pélvico são mais frequentes, aqui representadas pelo dobro $(n=16)$ daquelas ocorridas em membro torácico $(n=8)$. É provável que tal divergência relacione-se ao tipo de ave atendida, se cativa ou de vida livre, exímios voadores ou não. Redig (1986) e Souza, Fields e Degernes (2004) trabalharam apenas com rapinantes, e nos estudos de Howard (1990) e Kuzma e Hunter (1991) os rapinantes representaram no mínimo a metade dos pacientes, contrapondo-se ao nosso estudo, no qual apenas um caso de fratura ocorreu em rapinante de vida livre - um carcará (Caracara plancus) com fratura de úmero - e os psitaciformes, mantidos cativos em nosso meio sob condições de limitação de vôo, responderam por 21 dos 24 casos de fraturas operadas.

Dentro do contexto acima, o osso mais freqüentemente acometido por fratura também difere entre os estudos dos diversos autores, sendo o úmero para Redig (1986); Kuzma e Hunter (1991) e Souza, Fields e Degernes (2004), ao lado do tibiotarso para Howard (1990), o rádio e/ou ulna para McCartney (1994) e Santos et al. (2008) e o tibiotarso para Arnaut (2006). O tipo de ave e trauma sofrido estão diretamente relacionados ao osso acometido. A fratura de tibiotarso é uma das afecções ortopédicas mais comuns em pássaros cativos (KAVANAGH, 1997) e a mais freqüente em psitacídeos (HARCOURT-BROWN, 1996). De fato, neste estudo o tibiotarso mostrou-se como o osso mais fraturado tanto entre todas as aves, como também apenas entre os psitaciformes.

Segundo classificação modificada de Matera (1975) e adotada para este estudo, quanto à presença de comunicação externa, as fraturas fechadas $(66,67 \%$, $16 / 24)$ representaram um pouco mais que o dobro das fraturas expostas $(29,17 \%$, $7 / 24)$ e quanto ao número de linhas de fratura e de fragmentos ósseos, as fraturas simples $(66,67 \%, 16 / 24)$ prevaleceram sobre as duplas $(8,33 \%, 2 / 24)$ e cominutivas $(8,33 \%, 2 / 24)$. Na literatura não há um padrão na classificação de fraturas em aves, o que impossibilitou estabelecer comparação detalhada. Howard (1990) encontrou predomínio de fraturas fechadas em percentual que se aproxima ao encontrado no presente estudo $(60 \%, 6 / 10)$, enquanto Kuzma e Hunter (1991) observaram minoria de fraturas fechadas $(30 \%, 3 / 10)$. Como discutido anteriormente, em relação a membro e osso mais acometido, aqui o tipo de ave e trauma sofrido também relacionam-se diretamente às características da fratura. Apesar do tipo de injúria sofrido não ter sido estabelecido devido à ausência de dados relacionados, credita- 
se ao fato destas aves, em sua maioria serem cativas e não de vida livre, a menor ocorrência de fraturas expostas observada.

A ocorrência de apenas um caso de avulsão de extremidade de membro pélvico $(3,7 \%, 1 / 27)$ em um periquito-australiano (Melopsittacus undulatus), para o qual foi realizada a amputação do membro junto à articulação tarsometatársica, contrapõe-se a Quesenberry, Orosz e Dorrestein (1997), segundo os quais o traumatismo aos dígitos está entre as injúrias mais comumente vistas na clínica de aves.

Para o único caso de artrite e osteomielite $(3,7 \%, 1 / 27)$ observado em um tucano-toco (Ramphastos toco) e diagnosticado através de colheita de material (HP e CATB) como infecção bacteriana, os dados corroboram com a literatura, a articulação acometida foi a intertársica (ARNAUT, 2006) e a antibioticoterapia irresponsiva com evolução para o óbito, provavelmente por tratar-se de infecção grave com envolvimento ósseo (QUESENBERRY et al., 1997).

A escolha de uma técnica operatória apropriada para reparação ortopédica depende de diversas variáveis, dentre as quais o custo, o tipo de injúria, o osso envolvido, o comportamento natural, tamanho e grau de atividade da ave e a experiência do cirurgião (LEVITT, 1989; MARTIN; RITCHIE, 1994; BENNETT, 1997; HELMER; REDIG, 2006) parecem ter sido os fatores determinantes para que a fixação interna com pino IM tenha sido a mais utilizada no grupo das afecções cirúrgicas ortopédicas, visto tratar-se de técnica de baixo custo (LEVITT, 1989), indicada para a maioria das fraturas de tibiotarso, úmero e fêmur (BLASS, 1987; LEVITT, 1989; MACCOY, 1992; HARCOURT-BROWN, 1996; BENNETT, 1997), compatíveis para uso em aves de porte semelhante ou superior ao dos papagaios (BLASS, 1987; HARCOURT-BROWN, 1996; BENNETT, 1997), características relacionadas a este estudo.

A execução das técnicas operatórias para as afecções ortopédicas seguiu tanto os princípios básicos e fundamentais preconizados para a técnica cirúrgica em aves (GANDALL, 1982; ALTMAN, 1997a; RUPLEY, 1999; BOWLES et al., 2006; COLES, 2007; CUBAS; GODOY, 2007) como para a reparação ortopédica (REDIG, 1986; BLASS, 1987; LEVITT, 1989; MARTIN; RITCHIE, 1994; MACCOY, 1996; BENNETT, 1997; HELMER; REDIG, 2006), comprovado pelos bons resultados obtidos, tendo sido fixado como meta o retorno de cada paciente ao nível de atividade pré-injúria, preconizada e considerada nem sempre possível pelos autores 
(HELMER; REDIG, 2006). Para um total de 16 casos avaliados, 15 apresentaram retorno total e apenas um caso, de um papagaio-verdadeiro (Amazona aestiva), retorno parcial à função, considerado aceitável para pássaros de companhia, principalmente psitacídeos (BENNETT, 1997; KAVANAGH, 1997).

Para o tratamento cirúrgico dos casos de fraturas avaliados, a fixação interna com pino IM $(73,33 \%, 11 / 15)$ reafirmou a literatura, tendo sido a técnica mais utilizada para reparar este tipo de afecção (LEVITT, 1989; SOUZA; FIELDS; DEGERNES, 2004), e, ainda que desestimulada por Martin e Ritchie (1994) pelo seu "potencial" em causar injúria articular e periarticular e considerada por HarcourtBrown (1996) de difícil realização em papagaios, corrobora com Redig (1986) ao apresentar resultados satisfatórios, aqui representados por $72,72 \%$ de formação de calo ósseo e 18,18\% de reação periostal, 81,81\% de excelente eixo ósseo, 90,90\% de total e $9,09 \%$ de parcial retorno à função, atribuídos provavelmente ao fato de ter sido executada como preconiza a literatura (GANDAL, 1982; WITHROW, 1982; LEVITT, 1989; BENNETT, 1997; SOUZA; FIELDS; DEGERNES, 2004).

Os resultados obtidos com a fixação externa com transfixador (13,33\%, 2/15) confeccionado com polimetilmetacrilato, ao invés das barras de conexão de aço, como recomendam Satterfield e O'Rourke (1981), empregada em dois casos de fratura de úmero (MACCOY, 1992; BENNETT, 1997), um deles em um rapinante no qual se associou a fixação interna como indicado por alguns autores (CHEBEZ; AGUILAR, 2001; FOWLER, 2001), confeccionada com polímero de mamona (BOLSON et al., 2005), foram excelentes, com 100\% de calo ósseo formado e 100\% de total retorno à função, justificando sua recomendação na literatura (LEVITT, 1989; MARTIN; RITCHIE, 1994; BENNETT, 1997; ALIEVI, 2000), não tendo sido observado falhas, como a perda prematura dos pinos transfixantes encontrada por Redig (1986), ao tratar fraturas umerais em rapinantes.

Técnicas cirúrgicas ortopédicas desenvolvidas para serem utilizadas em rapinantes são impossíveis de serem aplicadas a um canário (HELMER; REDIG, 2006). Visto que a fixação com pinos é impossível de ser empregada em pequenos periquitos (HARCOURT-BROWN, 1996), e que enxertos ósseos corticais xenógrafos são uma alternativa viável para reparar fraturas em aves (BENNETT, 1997; WANDER et al., 2000), optou-se pela realização de fixação interna com enxerto heterólogo $(6,66 \%, 1 / 15)$ para reparar uma fratura exposta simples de tibiotarso em um periquito-verde (Brotogeris sp.), e pela ostectomia associada à tala $(6,66 \%, 1 / 15)$ 
para reparar uma fratura exposta de úmero antiga em uma calopsita (Nymphicus hollandicus), sendo que ambos apresentaram total retorno à função.

As corticais ósseas finas e frágeis das aves tendem a fragmentar-se quando submetidas à força, não reagindo bem a métodos convencionais de fixação como placas e parafusos (BLASS, 1987; LEVITT, 1989; KAVANAGH, 1997), raramente indicados, exceto para aves terrestres grandes, com corticais ósseas mais grossas (BLASS, 1987; BENNETT, 1997), além da desvantagem de necessitar de um tempo operatório maior se comparado a outras técnicas (BLASS, 1987; HOWARD, 1990; KAVANAGH, 1997) e de outro procedimento cirúrgico para a sua retirada (BLASS, 1987; KUZMA; HUNTER, 1991), justificando a ausência do emprego desta técnica constatada por este estudo.

Há poucos relatos de métodos para o tratamento de luxações em aves (BENNETT, 1997). A artrotomia para redução e a estabilização com transfixador unipolar transarticular como recomendada por Blass (1987) e Bennett (1997), foi a técnica operatória empregada para o único caso de luxação fechada de joelho ocorrida neste estudo, resultando em excelente eixo ósseo e total retorno à função, corroborando com Rosenthal, Hillyer e Mathiessen (1994). A ausência de informação quanto à avaliação radiográfica em relação à consolidação deve-se à natureza da afecção (luxação e não fratura) e ao tipo de técnica empregada: a fixação externa temporária para promover estabilização por fibrose periarticular (ROSENTHAL; HILLYER; MATHIESSEN, 1994) e não a artrodese que promove fusão definitiva (QUESENBERRY; OROSZ; DORRESTEIN, 1997).

\subsection{TECIDOS MOLES}

Com o crescimento do conhecimento e melhora da qualidade da clínica de aves, as doenças neoplásicas vêm se tornando mais que um diagnóstico posmortem (REAVILL, 2004), o que pode ser comprovado pelo predomínio das neoplasias $(30,16 \%, 19 / 63)$ sobre as demais afecções cirúrgicas de tecidos moles observadas neste estudo, superando também as taxas de ocorrência de tumores observadas por estudos na área da patologia de 3,9\% (REECE, 1992) e 5,8\% (GARNER, 2006) e no levantamento geral de doenças (4,95\%) notada por Santos et al. (2008). 
A maior freqüência de casos de neoplasias ocorre em Psittaciformes, segundo grande parte da literatura consultada (BLACKMORE, 1966; REECE, 1992; COLES, 2007; SINHORINI, 2008), e corrobora com os achados deste estudo, para o qual a ocorrência de neoplasias deu-se exclusivamente em exemplares psitaciformes, contrapondo-se a Garner (2006), que encontrou na ordem Anseriformes a maior taxa de prevalência tumoral. A ocorrência e popularidade distintas das aves nas diversas regiões do mundo podem justificar tais achados. $\mathrm{Na}$ literatura nacional encontram-se diversos relatos de caso de neoplasias em psitacídeos (ARAÚJO et al., 2007; FREITAS et al., 2008; SARMENTO; SANCHES; PACHALY, 2008).

Para Garner (2006) a calopsita (Nymphicus hollandicus) seguida do papagaio (Amazona sp.) foram as espécies psitaciformes com maior prevalência tumoral; já Sinhorini (2008) encontrou o periquito-australiano seguido do gênero Amazona, enquanto nosso estudo mostrou que o "grupo dos papagaios" respondeu pela maioria dos casos de neoplasias operados. Como discutido anteriormente, aves de pequeno porte apresentam maior grau de morbidade e mortalidade cirúrgica (HELMER; REDIG, 2006), o que pode justificar ter sido uma rosela (Platycercus eximius), o menor dos psitacídeos operados para exérese tumoral.

Uma grande variedade de doenças neoplásicas é vista em aves de estimação (SCHMIDT; QUESENBERRY, 1997). Neste estudo, o lipoma $(68,42 \%, 13 / 19)$ foi a neoplasia de maior ocorrência, corroborando em parte com Gandal (1982) e Latimer (1994), para os quais este tumor, ao lado de outros tipos neoplásicos, são os mais comuns. Em semelhança aos achados de Sinhorini (2008), os casos de lipomas acometeram em sua maioria papagaios obesos do gênero Amazona, sugerindo que fatores relacionados à dieta com altos índices energéticos e predisposição genética, mencionados por Latimer (1994), sejam a causa para que este tipo tumoral ocorra mais freqüentemente entre os psitaciformes (SCHMIDT; QUESENBERRY, 1997; REAVILL, 2004; LIGHTFOOT, 2006).

O linfoma, ainda pouco estudado em aves (LATIMER, 1994), apesar de considerado comum (GARNER, 2006), foi a segunda neoplasia de maior ocorrência observada neste estudo $(10,53 \%, 2 / 19)$, localizado no subcutâneo (SCHMIDT, QUESENBERRY, 1997) das regiões peitoral e tibiotársica, com óbito notificado em um dos casos. 
Os lipossarcomas raramente são encontrados nas aves (SCHMIDT; QUESENBERRY, 1997; REAVILL, 2004) e esteve representado neste estudo por um único caso $(5,26 \%, 1 / 19)$, que não apresentou recidiva dentro do período de estudo, apesar de tido como localmente agressivo (SCHMIDT; QUESENBERRY, 1997; REAVILL, 2004).

O hemangiossarcoma $(5,26 \%, 1 / 19)$ localizou-se no tecido cutâneo do membro pélvico, corroborando com a literatura (SCHMIDT; QUESENBERRY, 1997; REAVILL, 2004), porém não apresentou recidiva, como mencionado por Reavill (2004).

O carcinoma de células escamosas, considerado comum (GARNER, 2006), foi diagnosticado em apenas uma ave $(5,26 \%, 1 / 19)$ na cavidade oral, localização mencionada por Reavill (2004) e Lightfoot (2006), e o paciente foi eutanasiado em virtude do caráter agressivo do tumor (REAVILL, 2004).

O melanoma vem sendo diagnosticado em vários psitacídeos (REAVILL, 2004; SCHMIDT; LIGHTFOOT, 2006; STERN; LAMM, 2009), que não a arara-canindé (Ara ararauna), espécie acometida neste estudo por um melanoma mandibular (5,26\%, 1/19), cuja localização é uma das mais comumente citadas (REAVILL, 2004; SCHMIDT; QUESENBERRY, 1997). Assim como observado em uma cacatua por Stern e Lamm (2009), a evolução foi o óbito.

Como ainda são limitadas as informações publicadas quanto ao tratamento de neoplasias em aves (LIGHTFOOT, 2006), não foram encontrados estudos similares para efeito de comparação. Para o tratamento cirúrgico dos casos de neoplasias avaliados, a exérese $(82,35 \%, 14 / 17)$ foi a técnica mais utilizada reafirmando a literatura (SCHMIDT; QUESENBERRY, 1997; COLES, 2007), mostrou-se quanto ao pós-operatório imediato $100 \%$ excelente, ou seja, o tratamento cirúrgico foi considerado curativo, e quanto ao seguimento em longo prazo apenas 14,28\% apresentaram recidiva dentro do período de estudo, tratando-se do mesmo papagaio operado para excisão de lipoma pericloacal com intervalo de quatro anos entre a primeira e a segunda operação, e de três anos entre esta e a última. Nas cacatuas e nos papagaios os lipomas não se apresentam com limites bem definidos, o que dificulta a sua total exérese e, nos casos em que vasos sanguíneos tumorais infiltram o tecido adiposo, a excisão total torna-se impraticável (ALTMAN, 1997b), sendo comum sua recidiva (REAVILL, 2004). Nestes casos, portanto, suspeita-se que a ocorrência de recidiva esteve associada ao tipo tumoral e não à técnica 
operatória em si. Também deve ser considerado que a mudança na dieta e aumento dos exercícios (LATIMER, 1994; LIGHTFOOT, 2006) prescritos pelo clínico, provavelmente não foram seguidos pelo proprietário.

Os resultados obtidos com a biópsia incisional $(11,76 \%, 2 / 17)$ e com a colheita de material (HP e CATB) $(5,88 \%, 1 / 17)$ foram 100\% satisfatórios quanto ao pósoperatório imediato, ou seja, a intervenção cirúrgica apesar de não curativa, possibilitou o diagnóstico. Procedimentos desta natureza propiciam ao clínico de aves possibilidade de intervir de forma segura e adequada, objetivando a melhora da qualidade de vida destes pacientes, mesmo diante de afecções com prognóstico ruim.

As neoformações cutâneas ou de anexos não neoplásicos $(17,46 \%$, 11/63), que apresentaram a segunda maior ocorrência entre as afecções de tecidos moles operadas, acometeram exclusivamente os psitaciformes. O cáseo $(54,55 \%$, 6/11) foi a neoformação não neoplásica mais freqüente, corroborando com Godoy (2007), para o qual a remoção de cáseos constitui-se uma das intervenções cirúrgicas mais freqüentes em psitacídeos.

Os "cistos de pena", segunda neoformação não neoplásica de maior ocorrência $(27,27 \%, 3 / 11)$, discordando de Gandal (1982) e Quesenberry, Orosz e Dorrestein (1997), localizaram-se no carúnculo e cauda, e, apesar de jamais observado em aves silvestres por Coles (2007), acometeram exclusivamente papagaios.

Um único caso de xantoma $(9,09 \%, 1 / 11)$ foi diagnosticado na região peitoral (LIGHTFOOT, 2006; SCHMIDT; LIGHTFOOT, 2006) de um psitacídeo (REAVILL, 2004).

Nas aves, lesões granulomatosas causadas pelo Mycobacterium sp., podem acometer as articulações e estar presente na pele como nódulos repleto de material fibrinoso amarelado (GERLACH, 1994; POLLOCK, 2006), como observado no único caso de tuberculose $(9,09 \%, 1 / 11)$, diagnosticado através da colheita de material (HP e CATB) de formação nodular em região tibiotársica distal de um papagaioverdadeiro (Amazona aestiva).

Para o tratamento cirúrgico dos casos de neoformações cutâneas ou de anexos não neoplásicos avaliados, a exérese $(66,66 \%, 6 / 9)$ quanto ao pósoperatório imediato mostrou-se excelente (83,33\%), com apenas um caso de óbito ocorrido em até 24 horas da realização da operação $(16,66 \%)$, relacionado ou não 
ao erro na escolha da técnica operatória, visto tratar-se de neoformação caseosa, que deveria ter sido aberta e curetada cirurgicamente (COLES, 2007), e não submetida à tentativa de excisão completa. No entanto, em outro caso para o qual a drenagem de cáseo $(11,11 \%, 1 / 9)$ preconizada por Coles (2007) foi empregada, o óbito também ocorreu em até 24 horas, levantando a suspeita de que em ambos os casos os óbitos relacionaram-se às condições de debilidade orgânica pela afecção de base.

Os resultados obtidos com a biópsia incisional $(11,11 \%, 1 / 9)$ e com a colheita de material (HP e CATB) $(11,11 \%, 1 / 9)$ foram 100\% satisfatórios quanto ao pósoperatório imediato, ou seja, a intervenção cirúrgica apesar de não curativa possibilitou o diagnóstico, principal objetivo destas técnicas operatórias quando empregadas para diferenciar massas não neoplásicas, de aspecto variado, das neoplasias (BAUCK; OROSZ; DORRESTEIN, 1997; SCHMIDT; QUESENBERRY, 1997).

As neoformações cutâneas sem diagnóstico $(7,94 \%, 5 / 63)$ foram assim denominadas, pois não foi possível estabelecer o diagnóstico final quanto à sua etiologia, por motivos em sua maioria relacionados à decisão dos proprietários pela não realização de exames (HP, CATB e/ou necrópsia). Deve-se salientar, que este grupo de afecções, se portadores de um diagnóstico etiológico, ao constituírem-se casos ou do grupo das neoplasias ou do grupo das neoformações cutâneas e/ou de anexos não neoplásicos, não interfeririam na prevalência segundo a ordem de ocorrência, mas sim nos valores numéricos absolutos e percentuais.

Para o tratamento cirúrgico dos casos de neoformações cutâneas sem diagnóstico avaliados, a exérese $(50 \%, 2 / 4)$ mostrou-se 50\% excelente, sem recidiva, sendo que 50\% obitaram em até 24 horas da realização do procedimento cirúrgico, enquanto os resultados obtidos com a amputação $(25 \%, 1 / 4)$ e com a biópsia incisional $(25 \%, 1 / 4)$ mostraram para ambas 100\% de óbito em até 24 horas. Devido à ausência do diagnóstico quanto à etiologia destas neoformações, torna-se impossível estabelecer correlação entre o óbito e a técnica operatória ou condição clínica da ave operada.

A ocorrência de distocia entre as afecções de tecidos moles $(7,94 \%, 5 / 63)$ superou aquela encontrada por Santos et al. (2008) entre as doenças gerais de aves $(0,85 \%)$, resultado que se justifica pois este estudo esteve restrito às afecções cirúrgicas. Discordando em parte de Bennett e Harrison (1994), para os quais esta 
afecção acomete particularmente patos e psitacídeos, as espécies acometidas neste estudo pertenciam às ordens Psittaciformes, Columbiformes e Passeriformes.

Para o tratamento cirúrgico dos casos de distocia, a celiotomia $(60 \%, 3 / 5)$ com histerotomia para a remoção do ovo (COLES, 2007), foi a técnica empregada para os casos nos quais o ovo não pode ser visualizado pela cloaca (ALTMAN, 1997b), mostrando-se 33,33\% excelente sem recidiva na espécie Amazona sp. e com 66,66\% de óbito em até 24 horas da realização da operação nas espécies Columba livia e Serinus canaria, resultados que podem ser justificados pelo maior grau de morbidade e mortalidade cirúrgica em aves pequenas (HELMER; REDIG, 2006), além da condição clínica geral decorrente da afecção, sendo que a canária apresentava ovoperitonite e portanto prognóstico reservado (GANDAL, 1982).

O resultado obtido com a ovocentese $(40 \%, 2 / 5)$, realizada tanto pela via transcutânea abdominal como pela via cloacal (COLES, 2007), mostrou-se 100\% excelente, constituindo-se técnica menos invasiva e, portanto, mais segura principalmente para uso em aves de pequeno porte.

Dos vários segmentos do trato digestório das aves, o inglúvio foi o que mais necessitou de intervenção cirúrgica (GANDAL, 1982), devido à ocorrência de fístula de papo $(7,94 \%, 5 / 63)$ resultante da queimadura térmica causada pela administração de alimento superaquecido (BENNETT; HARRISON, 1994; RUPLEY, 1999), afecção que acometeu exclusivamente os psitaciformes, corroborando com Godoy (2007), para o qual o reparo de queimaduras ingluviais constitui-se uma das intervenções cirúrgicas mais freqüentes em psitacídeos.

Para o tratamento cirúrgico dos casos de fístula de papo avaliados, a ingluvioplastia foi a única técnica operatória empregada (100\%, 4/4) e mostrou-se excelente (75\%) sem recidiva, tendo sido executada conforme preconizado pelos autores (HALL, 1996; SIMPSON, 1996; FORBES, 2002), com um caso de óbito ocorrido em até 24 horas da realização da operação (25\%), associado à condição de grave debilidade no qual se encontrava a ave, uma anacã (Deroptyus accipitrinus) que já havia sido submetida a duas ingluvioplastias anteriores. Dois outros casos também já haviam sido operados anteriormente sem sucesso, provavelmente porque além da dificuldade de reparação cirúrgica diante de áreas extensas lesionadas (HALL, 1996; SIMPSON, 1996; FORBES, 2002), não foi aguardado tempo suficiente para que ocorresse a demarcação do tecido lesionado antes de realizar a operação, visto que, em decorrência da queimadura, os vasos 
esclerosados podem causar necrose tecidual além das margens da ferida e ocasionar deiscência pós-cirúrgica (ALTMAN, 1997b).

Forbes (2002) refere que a hérnia abdominal é encontrada com maior freqüência em fêmeas obesas de psitacídeos, principalmente de cacatuas e periquitos, assemelhando-se em parte aos resultados obtidos, que mostraram a ocorrência de hérnia abdominal $(4,76 \%, 3 / 63)$ em dois psitacídeos, sem identificação do sexo, um deles um periquito-australiano e o outro um papagaioverdadeiro, além de acometer uma fêmea de pato-doméstico representante da ordem Anseriformes, que havia efetuado postura recentemente, o que provavelmente resultou em pressão à musculatura abdominal causando a hérnia (GANDAL, 1982).

Para o tratamento cirúrgico dos casos de hérnia abdominal avaliados, a herniorrafia abdominal $(100 \%, 2 / 2)$, cuja técnica operatória foi similar àquela utilizada para os mamíferos (GANDAL, 1982), sem necessidade de recorrer à técnica de abdominoplastia (ALTAMN, 1997b), mostrou-se 100\% excelente sem recidiva.

Altman (1997b) afirma que a infecção dos seios é um dos problemas respiratórios mais comuns encontrado nas aves, principalmente em psitacídeos, e Godoy (2007) cita a remoção de cáseos ou coleções líquidas decorrentes das sinusites como uma das intervenções cirúrgicas mais freqüentes para estas aves. De fato, neste estudo, a sinusite $(4,76 \%, 3 / 63)$ que acometeu exclusivamente os psitaciformes, aparece como a quarta afecção cirúrgica de tecidos moles de maior ocorrência neste grupo $(5,17 \%, 3 / 58)$.

Quanto ao tratamento cirúrgico para os casos de sinusite avaliados, a drenagem de cáseo associada à colheita de material (CATB) (100\%, 2/2), preconizada por Altman (1997b), mostrou-se 100\% excelente, sendo o tratamento considerado curativo, o que nos faz discordar de Forbes (1996) e Bowles et al. (2006), que recomendam a trepanação dos seios apenas como último recurso para os casos nos quais a lavagem com antibióticos não obteve sucesso.

Lacerações causadas por mordedura em um pombo-doméstico (Columba livia) e por um CE em uma arara-canindé (Ara ararauna) representaram as causas de perfuração de esôfago $(3,17 \%, 2 / 63)$ observadas neste estudo e sustentadas por Forbes (2002). Ambos os casos foram submetidos à esofagoplastia (100\%, 2/2), que se mostrou excelente sem recidiva para o pombo-doméstico, e resultou no óbito em até 24 horas da realização do procedimento cirúrgico para a arara-canindé. Pode-se 
atribuir o sucesso da esofagoplastia no pombo, à reparação cirúrgica imediata e à capacidade de distensão do esôfago, observada nos columbídeos (VOGEL; GERLACH, LÖFFLER, 1994). O óbito da arara relacionou-se à debilidade orgânica da ave pela cronicidade da afecção.

Enquanto na literatura internacional as cacatuas são consideradas os psitacídeos mais acometidos por prolapso de cloaca (BENNETT; HARRISON, 1994; ALTMAN, 1997b; FORBES, 2002; BOWLES et al., 2006), este estudo mostrou o papagaio-verdadeiro (Amazona aestiva) como a única espécie de psitacídeo acometido por esta afecção $(3,17 \%, 2 / 63)$. Se considerarmos que a sua etiologia ainda é desconhecida, atribuída a um déficit neuromuscular da parede da cloaca com redução do tônus do esfíncter (BENNETT; HARRISON, 1994; ALTMAN, 1997b; BOWLES et al., 2006), que pode estar relacionado à masturbação crônica, colacites (BOWLES et al., 2006), tumores ou à postura de ovos (COLES, 2007), é provável que as espécies tidas como "mais acometidas" não representem as mais predispostas mas sim aquelas que ocorrem em maior freqüência no local do estudo.

Para o tratamento cirúrgico dos casos de prolapso de cloaca, a redução de prolapso e sutura em bolsa-de-fumo foi a única técnica operatória empregada $(100 \%, 2 / 2)$, e mostrou-se excelente sem recidiva para uma das aves, visto não tratar-se de prolapso total que ocluía ureteres/cólon ou prolapso recorrente, para os quais a cloacopexia seria a técnica indicada (BENNETT; HARRISON, 1994; COLES, 2007). Associou-se o óbito ocorrido em até 24 horas da realização da operação para o segundo caso, à condição de grave debilidade no qual se encontrava a ave.

A freqüência de casos de gangrena de extremidade de membros $(3,17 \%$, 2/63) decorrentes de extensa lesão aos tecidos moles, que acometeu um periquitoverde (Brotogeris sp.) e um periquito-australiano (Melopsittacus undulatus), não correspondeu à assertiva de Quesenberry, Orosz e Dorrestein (1997), de que as feridas traumáticas de dígitos estão entre as injúrias mais comumente vistas na prática da clínica aviária, assim como a "Necrose avascular de dígito" (1,59\%, 1/63), considerada freqüente em psitacídeos pelos mesmos autores, foi representada por um único caso observado em uma arara-canindé (Ara ararauna), correspondendo a apenas $1,72 \%$ das afecções cirúrgicas de tecidos moles que acometeram os psitaciformes, e cujo exame HP revelou uma dermatite hiperplásica crônica de dígito, sem evidência de constricção mecânica, hipótese etiológica defendida por Harcourt-Brown (1996). 
A amputação $(100 \%, 2 / 2)$ empregada para o único caso de "Necrose avascular de dígito" e para um dos casos de gangrena de extremidade de membro, técnica operatória preconizada para uso nestas afecções (BENNETT; HARRISON, 1994; QUESENBERRY; OROSZ; DORRESTEIN, 1997; BOWLES et al., 2006), mostrou-se excelente.

Um único caso de perfuração de cavidade celomática $(1,59 \%, 1 / 63)$ ocorreu em um papagaio-verdadeiro (Amazona aestiva) causado pela mordedura de outro animal (QUESENBERRY; OROSZ; DORRESTEIN, 1997) e foi submetido à laparorrafia com óbito em até 24 horas da realização do procedimento cirúrgico devido à gravidade do trauma. Corroboramos com Simpson (1996), para o qual as injúrias traumáticas estão entre as afecções mais encontradas pelos veterinários que trabalham com psitacídeos, se incluirmos além desta, todas as outras afecções cirúrgicas de origem traumática que acometeram os psitacídeos, vistas anteriormente.

Formações neoplásicas ou de outra origem em cavidade celomática podem apresentar-se com sinais de dispnéia em psitacídeos (FORBES, 1996), como observado em um papagaio-verdadeiro (Amazona aestiva) com neoformação em cavidade celomática sem diagnóstico $(1,59 \%, 1 / 63)$, submetido à colocação de sonda em saco aéreo abdominal caudal para alívio da dispnéia, associada à endoscopia para tentativa de diagnóstico sem sucesso, com óbito do paciente nas primeiras 24 horas da realização do procedimento cirúrgico.

Corpos estranhos que saem do papo podem se alojar em qualquer parte do sistema digestório (GANDAL, 1982). De fato, o único caso de CE em trato gastrointestinal $(1,59 \%, 1 / 63)$, localizado em proventrículo e ventrículo de um papagaio-verdadeiro (Amazona aestiva), tratava-se de uma sonda empregada para alimentar a ave, que foi retirada com sucesso através da ingluviotomia associada à endoscopia, técnicas operatórias comumente utilizadas para a remoção de CE em aves (RUPLEY, 1999; FORBES, 2002; CUBAS; GODOY, 2007).

$\mathrm{Na}$ literatura a ocorrência de feridas na quilha é associada à colisão com objetos, queda ou tentativa frustrada de vôo (ALTMAN, 1997b, BOWLES et al., 2006), não correspondendo à etiologia do único caso de ferida na região da quilha $(1,59 \%, 1 / 63)$ observado em um papagaio-verdadeiro (Amazona aestiva), causado pela mordedura de outro animal, confirmando mais uma vez, no entanto, que injúrias 
traumáticas estão entre as afecções mais encontradas pelos veterinários que trabalham com psitacídeos (SIMPSON, 1996).

Apesar da contaminação e exposição do tecido subcutâneo e periósteo dificultarem a cicatrização das bordas da ferida na região da quilha, sendo freqüentemente considerado ineficaz o debridamento e sutura simples, diante da pouca elasticidade da pele e dificuldade de realizar uma sutura livre de tensão (ALTMAN, 1997b), neste caso, debridamento e síntese constituíram técnica operatória suficiente para promover a cicatrização por primeira intenção, considerada excelente sem recidiva, resultado também observado em psitacídeos com lesões ulceradas no esterno causadas por automutilação (HOCHLEITHNER; HOCHLEITHNER, 1996).

Apesar de pouco freqüente, a otite é a afecção de ouvido mais citada na literatura, e pode necessitar de curetagem para auxílio no tratamento médico (ALTMAN, 1997b; KERN, 1997), informações que correspondem ao que foi demonstrado por este estudo, respectivamente, um único caso de otite $(1,59 \%$, 1/63) em um papagaio-verdadeiro (Amazona aestiva), submetido à drenagem e colheita material (CATB) para orientar a antibioticoterapia.

A execução de operações realizadas em aves, e registradas a partir de 2000 como parte da rotina do Serviço de Cirurgia de Pequenos Animais do HOVETFMVZ/USP, responsável pelo atendimento clínico-cirúrgico a cães e gatos, surgiu pela demanda por tratamento cirúrgico para esta classe de animais, atendidas pelo Ambulatório de Aves. O aprimoramento da técnica operatória foi viabilizado pelo avanço na área da anestesiologia, e os bons resultados refletem a atuação conjunta da tríade clínico-cirurgião-anestesista.

Por tratar-se do primeiro estudo retrospectivo relacionado à casuística de operações em aves desenvolvido no Brasil, e considerando sua importância para o mapeamento das diferentes afecções que possam necessitar de tratamento cirúrgico, estudos futuros sobre o tema devem ser empreendidos no país, que é a terceira maior biodiversidade desta classe de animais no mundo. 
CONCLUSÕES 



\section{CONCLUSÕES}

A partir dos resultados observados neste estudo retrospectivo das operações realizadas em aves em nosso meio, pode-se concluir que:

$\checkmark$ A ocorrência de afecções cirúrgicas de tecidos moles superou a de afecções cirúrgicas ortopédicas.

$\checkmark$ O membro pélvico foi mais acometido que o torácico por afecções cirúrgicas ortopédicas.

$\checkmark$ Dentre as afecções cirúrgicas ortopédicas as fraturas foram as mais freqüentes e o tibiotarso o osso mais fraturado.

$\checkmark$ A ocorrência de fraturas fechadas superou a de expostas e a ocorrência de fraturas simples superou a de duplas e cominutivas.

$\checkmark$ A fixação interna com pino intramedular foi a técnica operatória mais utilizada nas afecções cirúrgicas ortopédicas. Para os casos avaliados de tratamento das fraturas esta técnica operatória apresentou elevado índice de retorno à função.

$\checkmark$ Dentre as afecções cirúrgicas de tecidos moles, as neoplasias apresentaram a maior ocorrência e o lipoma foi a neoplasia mais freqüente, seguida pelas neoformações cutâneas ou de anexos não neoplásicos representadas em sua maioria pelo cáseo. 
$\checkmark$ A exérese foi a técnica operatória mais utilizada nas afecções cirúrgicas de tecidos moles. Para os casos avaliados relacionados ao tratamento cirúrgico das neoplasias e das neoformações cutâneas ou de anexos não neoplásicos, esta técnica operatória apresentou índices elevados de cura e baixa ocorrência de recidivas.

$\checkmark$ As aves mais freqüentemente operadas e que apresentaram a maior ocorrência de afecções cirúrgicas ortopédicas e de tecidos moles pertenciam à ordem Psittaciformes e ao "grupo dos papagaios", representado em sua maioria por espécies do gênero Amazona.

$\checkmark$ O conhecimento das afecções cirúrgicas e das espécies de aves mais acometidas, bem como dos resultados obtidos com as técnicas operatórias empregadas, acrescentam informações para aqueles que atuam nesta área e servem como indicador de estudo para futuros cirurgiões de aves. 
REFERÊNCIAS 



\section{REFERÊNCIAS}

ALIEVI, M. M. Redução fechada e fixação esquelética externa tipo I ou II para o tratamento de fratura de tibiotarso em pombos domésticos (Columba livia). 2000. 38 f. Dissertação (Mestrado em Medicina Veterinária) - Universidade Federal de Santa Maria, Santa Maria, Rio Grande do Sul, 2000.

ALIEVI, M. M.; HIPPLER, R. A.; GIACOMELLI, L.; GUIMARÃES, L.; SCHOSSLER, J. E. Fixação esquelética externa para artrodese de joelho em papagaio (Amazona aestiva). Ciência Rural, Santa Maria, v. 31, n. 6, p. 1069-1072, 2001.

ALTMAN, R. B. General surgical considerations. In: ALTMAN, R. B.; CLUBB, S. L.; DORRESTEIN, G. M.; QUESENBERRY, K. Avian medicine and surgery. Philadelphia: W. B. Saunders, 1997a. p. 691-703.

ALTMAN, R. B. Soft tissue surgical procedures. In: ALTMAN, R. B.; CLUBB, S. L.; DORRESTEIN, G. M.; QUESENBERRY, K. Avian medicine and surgery.

Philadelphia: W. B. Saunders, 1997b. p. 704-732.

ALTMAN, R. B. Twenty years of progress in avian anesthesia and surgery. Journal of the American Veterinary Medical Association, v. 212, n. 8, p. 1233-1235, 1998.

ALTMAN, R. B.; CLUBB, S. L.; DORRESTEIN, G. M.; QUESENBERRY, K. Avian medicine and surgery. Philadelphia: W. B. Saunders, 1997. 1070 p.

ARAúJO, A. C. P.; CARVALHO, A. D.; NASCIMENTO, P. B.; VOLL, J.; DREIMEIER, D. Rabdomiossarcoma alveolar em papagaio (Amazona aestiva). Acta Scientiae Veterinaria, v. 35, p. 115-117, 2007.

ARNAUT, L. S. Estudo radiográfico das afecções do sistema esquelético em aves. 2006. 121 f. Dissertação (Mestrado em Clínica Cirúrgica Veterinária) Faculdade de Medicina Veterinária e Zootecnia, Universidade de São Paulo, São Paulo, 2006.

AVIBASE. The world bird database (2009). Disponível em: <http://www.ao.com.br> Acesso em: 20 out. 2009. 
BAILLIE, J.; GROOMBRIDGE, B. 1996 IUCN red list of threatened animals. Washington: Kelvyn Press, 1996. 368 p.

BAUCK, L.; OROSZ, S.; DORRESTEIN, G. M. Avian dermatology. In: ALTMAN, R. B.; CLUBB, S. L.; DORRESTEIN, G. M.; QUESENBERRY, K. Avian medicine and surgery. Philadelphia: W. B. Saunders, 1997. p. 540-562.

BENNETT, R. A. Orthopedic surgery. In: ALTMAN, R. B.; CLUBB, S. L.; DORRESTEIN, G. M.; QUESENBERRY, K. Avian medicine and surgery. Philadelphia: W. B. Saunders, 1997. p. 733-766.

BENNETT, R. A.; HARRISON, G. J. Soft tissue surgery. In: RITCHIE, B. W.; HARRISON, G. J.; HARRISON, L. R. Avian medicine: principles and application. Florida: Wingers, 1994. p. 1096-1136.

BLACKMORE, D. K. The clinical approach to tumors in cage birds. I. The pathology and incidence of neoplasia in cage birds. Journal of Small Animal Practice, v. 7, n. 3, p. 217-223, 1966.

BLASS, C. E. Orthopedics. In: BURR, E. W. Companion bird medicine. Ames: lowa State University Press, 1987. p. 155-165.

BOLSON, J.; SCHOSSLER, J. E. W.; MACHADO, G.; ZEMBRZUSKI, F. B. Pino ósseo homólogo conservado em glicerina a 98\% e hemicerclagem com fio poliglactina 910 na osteossíntese umeral de pombos domésticos. Ciência Rural, Santa Maria, v. 38, n. 7, p. 1925-1931, out, 2008.

BOLSON, J.; SCHOSSLER, J. E. W.; ORNES, R. C.; MOTTIN, V.; ALBERTI, T. Análise clínica, radiográfica, macroscópica e histológica do úmero de codornas domésticas (Coturnix japonica), submetido ao implante da poliuretana derivada do polímero de mamona (Ricinnus communis). Ciência Rural, Santa Maria, v. 35, n. 5, p. 1123-1130, set-out, 2005.

BOWLES, H. L.; ODBERG, E.; HARRISON, G. J.; KOTTWITZ, J. J. Surgical resolution of soft tissue disorders. In: HARRISON, G. J.; LIGHTFOOT, T. L. Clinical avian medicine. Florida: Spix, 2006. v. 2, p. 775-829.

BORMAN, E. R.; PUTNEY, D. L. Repair of a wing fracture with methylmethacrylate bone cement. Veterinary Medicine/Small Animal Clinician, v. 73, p. 794, 1978. 
BORMAN, E. R.; PUTNEY, D. L.; JESSUP, D. Use of acrylic bone cement in avian orthopedics. Journal of the American Animal Hospital Association, v. 14, p. 602604, 1978.

BRASIL. Instituto Brasileiro do Meio Ambiente e dos Recursos Naturais Renováveis. Portaria n. 117, 1997. Disponível em:

<htpp://www.ibama.gov.br/fauna/legislacao/port_117_97.pdf>. Acesso em: 20 nov. 2007.

BRASIL. Ministério do Meio Ambiente. Instrução Normativa $\mathbf{n}^{\circ}$ 3, de 26 de maio de 2003a. Disponível em:

<http://www.icmbio.gov.br/sisbio/legislacao.php?id_arq=29>. Acesso em: 20 out. 2009.

BRASIL. Ministério do Meio Ambiente. Anexo à Instrução Normativa n 3, de 27 de maio de 2003b. Disponível em:

<http://www.ibama.gov.br/fauna/downloads/lista\%20spp.pdf>. Acesso em: 20 out. 2009.

BURR, E. W. Companion bird medicine. Ames: Iowa State University Press, 1987. $247 \mathrm{p}$.

CATÃO-DIAS, J. L.; CARVALHO, V. M. Tuberculose. In: CUBAS, Z. S.; SILVA, J. C. R.; CATÃO-DIAS, J. L. Tratado de animais selvagens - medicina veterinária. São Paulo: Roca, 2007. p. 726-735.

CBRO. Comitê Brasileiro de Registros Ornitológicos (2009). Listas das aves do Brasil. 8. ed. Versão 9/8/2009. Disponível em <http://www.cbro.org.br>. Acesso em: 20 out. 2009.

CHEBEZ, J. C.; AGUILAR, R. F. Order Falconiformes (hawks, eagles, falcons, vultures). In: FOWLER, M. E.; CUBAS, Z. S. Biology, medicine and surgery of south american wild animals. Ames: Iowa State University Press, 2001. p. 115124.

CHINNADURAI, S. K.; SPODNICK, G.; DEGERNES, L.; DEVOE, R. S.; MARCELLIN-LITTLE, D. J. Use of an extracapsular stabilization technique to repair cruciate ligament ruptures in two avian species. Journal of Avian Medicine and Surgery, v. 23, n. 4, p. 307-313, 2009. 
COLES, B. H. Avian medicine and surgery. Oxford: Blackwell Publishing, 1985. $288 \mathrm{p}$.

COLES, B. H. Surgery. In: Essentials of avian medicine and surgery. 3. ed. Oxford: Blackwell Publishing, 2007. p. 142-182.

COLES, B. H. Wing problems. In: BEYNON, P. H.; FORBES, N. A.; LAWTON, M. P. C. Manual of psittacine birds. Cheltenham: BSAVA, 1996. p. 134-146.

CUBAS, Z. S. Piciformes (tucano, araçari, pica-pau). In: CUBAS, Z. S.; SILVA, J. C. R.; CATÃO-DIAS, J. L. Tratado de animais selvagens - medicina veterinária. São Paulo: Roca, 2007. p. 210-221.

CUBAS, Z. S.; GODOY, S. N. Medicina e patologia de aves de companhia. In: AGUILAR, R.; HERNÁNDEZ-DIVERS, S. M.; HERNÁNDEZ-DIVERS, S. J. Atlas de medicina, terapêutica e patologia de animais exóticos. São Caetano do Sul: Interbook, 2007. p. 213-264.

CUBAS, Z. S.; SILVA, J. C. R.; CATÃO-DIAS, J. L. Tratado de animais selvagens - medicina veterinária. São Paulo: Roca, 2007. 1354 p.

DYCE, K. M.; SACK, W. O.; WENSING, C. J. G. Tratado de anatomia veterinária. 2. ed. Rio de Janeiro: Guanabara Koogan, 1997. p. 631-650.

DILGER, W. C. Common types of cage birds. In: PETRAK, M. L. Diseases of cage and aviary birds. 2. ed. Philadelphia: Lea \& Febiger, 1982. p. 3-10.

EVANS, H. E. Anatomy of the budgerigar. In: PETRAK, M. L. Diseases of cage and aviary birds. 2. ed. Philadelphia: Lea \& Febiger, 1982. p. 111-189.

FEDUCCIA, A. Osteologia das aves. In: GETTY, R. Anatomia dos animais domésticos. 5. ed. Rio de Janeiro: Guanabara Koogan, 1986. p. 1680-1690.

FILIPPICH, L. J. Tumor control in birds. Seminars in Avian and Exotic Pet Medicine, v. 13, n. 1, p. 25-43, 2004.

FORBES, N. A. Fracture treatment in raptors. International Falconer, v. 4, p. 36-39, 2000. 
FORBES, N. A. Avian gastrointestinal surgery. Seminars in Avian and Exotic Pet Medicine, v. 11, n. 4, p. 196-207, 2002.

FORBES, N. A. Respiratory problems. In: BEYNON, P. H.; FORBES, N. A.; LAWTON, M. P. C. Manual of psittacine birds. Cheltenham: BSAVA, 1996. p. 147157.

FORBES, N. A.; LAWTON, M. P. C. Introduction. In: BEYNON, P. H.; FORBES, N. A.; LAWTON, M. P. C. Manual of psittacine birds. Cheltenham: BSAVA, 1996. p. 710.

FOTIN, C. M. P. Levantamento prospectivo dos animais silvestres, exóticos e domésticos não convencionais, em cativeiro domiciliar, atendidos em clínicas particulares no município de São Paulo: aspectos do manejo e principais afecções. 2005. 206 f. Dissertação (Mestrado em Patologia Experimental e Comparada) - Faculdade de Medicina Veterinária e Zootecnia, Universidade de São Paulo, São Paulo, 2005.

FOWLER, M. E. Order Strigiformes (owls). In: FOWLER, M. E.; CUBAS, Z. S. Biology, medicine and surgery of south american wild animals. Ames: Iowa State University Press, 2001. p. 125-132.

FOWLER, M. E.; CUBAS, Z. S. Biology, medicine and surgery of south american wild animals. Ames: Iowa State University Press, 2001. 536 p.

FREITAS, A. A. R.; LEVY, M. G. B.; NOGUEIRA, D. M.; LIPARISI, F.; TORTELLY, R. Carcinoma de células basais em periquito australiano (Melopsittacus undulatus): relato de caso. Revista Brasileira de Ciência Veterinária, v. 15, n. 1, p. 25-27, 2008.

GALETTI, M.; PIZO, M. A. Ecologia e conservação de psitacídeos no Brasil. Belo Horizonte: Melopsittacus Publicações Científicas, 2002. 235 p.

GANDAL, C. P. Anesthetic and surgical techniques. In: PETRAK, M. L. Diseases of cage and aviary birds. 2. ed. Philadelphia: Lea \& Febiger, 1982. p. 304-328.

GARNER, M. M. A retrospective study of case submissions to a specialty diagnostic service. In: HARRISON, G. J.; LIGHTFOOT, T. L. Clinical avian medicine. Florida: Spix, 2006. v. 2, p. 566-571. 
GERLACH, H. Bacteria. In: RITCHIE, B. W.; HARRISON, G. J.; HARRISON, L. R. Avian medicine: principles and application. Florida: Wingers, 1994. p. 949-983.

GILL, F. B. Ornithology. 2. ed. New York: W. H. Freeman and Company, 1995. 766 p.

GODOY, S. N. Psittaciformes (arara, papagaio, periquito). In: CUBAS, Z. S.; SILVA, J. C. R.; CATÃO-DIAS, J. L. Tratado de animais selvagens - medicina veterinária. São Paulo: Roca, 2007. p. 222-251.

GONDIM, L. S. Q.; GOMES, D. M.; MAIA, P. C. C. Casuística de aves selvagens atendidas de 2002 a 2004 na Escola de Medicina Veterinária da Universidade Federal da Bahia. In: CONGRESSO BRASILEIRO DE ZOOLOGIA, 26., 2006, Londrina. Resumos... [Londrina: s. n.], 2006. p. 86-87.

GREENACRE, C. B. The avian patient. In: BALLARD, B.; CHEEK, R. Exotic animal medicine for the veterinary technician. Ames: Blackwell, 2003. p. 15-29.

GRESPAN, A. Anseriformes (pato, cisne, ganso, marreco). In: CUBAS, Z. S.; SILVA, J. C. R.; CATÃO-DIAS, J. L. Tratado de animais selvagens - medicina veterinária. São Paulo: Roca, 2007. p. 185-209.

GUIMARÂES, M. B. Passeriformes (pássaro, canário, saíra, gralha). In: CUBAS, Z. S.; SILVA, J. C. R.; CATÃO-DIAS, J. L. Tratado de animais selvagens - medicina veterinária. São Paulo: Roca, 2007. p. 324-337.

HALL, C. J. Diarrhoea and vomiting. In: BEYNON, P. H.; FORBES, N. A.; LAWTON, M. P. C. Manual of psittacine birds. Cheltenham: BSAVA, 1996. p.171-185.

HARRISON, G. J.; HARRISON, L. R. Clinical avian medicine and surgery including aviculture. Philadelphia: W. B. Saunders, 1986. 717 p.

HARRISON, G. J.; LIGHTFOOT, T. L. Clinical avian medicine. Florida: Spix, 2006. $1008 \mathrm{p}$.

HARCOURT-BROWN, N. H. Pelvic limb problems. In: BEYNON, P. H.; FORBES, N. A.; LAWTON, M. P. C. Manual of psittacine birds. Cheltenham: BSAVA, 1996. p. 123-133. 
HELMER, P.; REDIG, P. T. Surgical resolution of orthopedic disorders. In: HARRISON, G. J.; LIGHTFOOT, T. L. Clinical avian medicine. Florida: Spix, 2006. v. 2, p. 761-773.

HOCHLEITHNER, M.; HOCHLEITHNER, C. Surgical treatment of ulcerative lesions caused by automutilation of the sternum in psittacine birds. Journal of Avian Medicine and Surgery, v. 10, n. 2, p. 84-88, 1996.

HOEFER, H. L.; OROSZ, S.; DORRESTEIN, G. M. The gastrointestinal tract. In: ALTMAN, R. B.; CLUBB, S. L.; DORRESTEIN, G. M.; QUESENBERRY, K. Avian medicine and surgery. Philadelphia: W. B. Saunders, 1997. p. 412-453.

HOLZ, P. H. Coracoid fractures in wild birds: repair and outcomes. Australian Veterinary Journal, v. 81, n. 8, p. 469-471, 2003.

HOWARD, P. E. The use of bone plates in the repair of avian fractures. Journal of the American Animal Hospital Association, v. 26, p. 613-622, 1990.

JOHNSON-DELANEY, C. A. J. Exotic companion medicine handbook for veterinarians. Lake Worth: Wingers, 1996. 270 p.

KAVA, U.; KAVA, A.; KIBAR, M. An operative treatment of a pelican with distal oblique humeral fracture. Ankara Universitesi Veteriner Fakultesi Dergisi, v. 48, n. 1, p. 13-16, 2001.

KAVANAGH, M. Tibiotarsal fracture repair in a scarlet macaw using external skeletal fixation. Journal of Small Animal Practice, v. 38, p. 296-298, 1997.

KERN, T. J. Disorders of the special senses. In: ALTMAN, R. B.; CLUBB, S. L.; DORRESTEIN, G. M.; QUESENBERRY, K. Avian medicine and surgery. Philadelphia: W. B. Saunders, 1997. p. 563-589.

KUZMA, A. B.; HUNTER, B. A new technique for avian fracture repair using intramedullary polymethylmethacrylate and bone plate fixation. Journal of the American Animal Hospital Association, v. 27, p. 239-248, 1991.

LANGLOIS, I.; JONES, M. P. Ventral abdominal hernia associated with hepatic lipidosis in a red lory (Eos bornea). Journal of Avian Medicine and Surgery, v. 15, n. 3, p. 216-222, 2001. 
LATIMER, K. S. Oncology. In: RITCHIE, B. W.; HARRISON, G. J.; HARRISON, L. R. Avian medicine: principles and application. Florida: Wingers, 1994. p. 640-669.

LEVITT, L. Avian orthopedics. Compendium Continuing Education Practicing Veterinarian, v. 11, n. 8, p. 899-910, 1989.

LIGHTFOOT, T. L. Clinical avian neoplasia and oncology. In: HARRISON, G. J.; LIGHTFOOT, T. L. Clinical avian medicine. Florida: Spix, 2006. v. 2, p. 560-565.

MACCOY, D. M. High density polymer rods as an intramedullary fixation device in birds. Journal of the American Animal Hospital Association, v. 19, set-out, p. 767-772, 1983.

MACCOY, D. M. Orthopedic surgery. In: ROSSKOPF, W. J.; WOERPEL, R. W. Diseases of cage and aviary birds. 3. ed. Baltimore: Williams \& Wilkins, 1996. p. 722-738.

MACCOY, D. M. Treatment of fractures in avian species. Veterinary Clinic of North American Animal Practice, v. 22, n. 1, p. 225-238, 1992.

MARTIN, H.; RITCHIE, B. W. Orthopedic surgical techniques. In: RITCHIE, B. W.; HARRISON, G. J.; HARRISON, L. R. Avian medicine: principles and application. Florida: Wingers, 1994. p. 1137-1169.

MATERA, E. A. Traumatismos. In: Lições de patologia cirúrgica geral. Belo Horizonte: Cooperativa Veterinária de Consumo Ltda., 1975. p. 53-118.

MCCARTNEY, W. T. Orthopaedic injuries in pigeons. Veterinary Record, v. 134, p. 305-307, 1994.

NEWTON, C. D.; ZEITLIN, S. Avian fracture healing. Journal of the American Veterinary Medical Association, v. 170, n. 6, p. 620-625, 1977.

O'MALLEY, B. Avian anatomy and physiology. In: Clinical anatomy and physiology of exotic species. Structure and function of mammals, birds, reptiles and amphibians. Edinburgh: Elsevier Saunders, 2005. p. 97-161. 
OROSZ, S. Anatomy of the respiratory system. Respiratory system. In: ALTMAN, R. B.; CLUBB, S. L.; DORRESTEIN, G. M.; QUESENBERRY, K. Avian medicine and surgery. Philadelphia: W. B. Saunders, 1997. p. 387-390.

OROSZ, S. E.; ENSLEY, P. K.; HAYNES, C. J. Avian surgical anatomy: thoracic and pelvic limb. Philadelphia: W. B. Saunders, 1992. 139 p.

PEREIRA, R. J. G. Falconiformes e Strigiformes (águia, gavião, falcão, abutre, coruja). In: CUBAS, Z. S.; SILVA, J. C. R.; CATÃO-DIAS, J. L. Tratado de animais selvagens - medicina veterinária. São Paulo: Roca, 2007. p. 252-267.

PIERMATTEI, D. L.; FLO, G. L.; DECAMP, C. E. Fractures: Classification, diagnosis, and treatment. In: Brinker, Piermattei and Flo's handbook of small animal orthopedics and fracture repair. 4. ed. St. Louis: W. B. Saunders, 2006. p. 25-159.

POLLOCK, C. G. Implications of Mycobacteria in clinical disorders. In: HARRISON, G. J.; LIGHTFOOT, T. L. Clinical avian medicine. Florida: Spix, 2006. v. 2, p. 681690.

PUTNEY, D. L.; BORMAN, E. R.; LOHSE, C. L. Methylmethacrylate fixation of avian humeral fractures: a radiographic histologic study. Journal of the American Animal Hospital Association, v. 19, p. 773-782, 1983.

QUESENBERRY, K.; OROSZ, S.; DORRESTEIN, G. M. Musculoskeletal system. In: ALTMAN, R. B.; CLUBB, S. L.; DORRESTEIN, G. M.; QUESENBERRY, K. Avian medicine and surgery. Philadelphia: W. B. Saunders, 1997. p. 517-539.

RADLINSKY, M. A. G.; CARPENTER, J. W.; MISON, M. B. ARMBRUST, L. J. Colonic entrapment after cloacopexy in two psittacine birds. Journal of Avian Medicine and Surgery, v. 18, n. 3, p. 175-182, 2004.

REAVILL, D. R. Tumors of pet birds. Veterinary Clinics Exotic Animal Practice, v. 7, p. 537-560, 2004.

REDIG, P. T. A clinical review of orthopedic techniques used in the rehabilitation of raptors. In: FOWLER, M. E. Zoo \& wild animal medicine. 2. ed. Philadelphia: W. B. Saunders, 1986. p. 388-401. 
REECE, R. L. Observations on naturally occurring neoplasms in birds in the sate of Victoria, Australia. Avian Pathology, v. 21, p. 3-32, 1992.

REIS, J. Doenças das aves: manual prático para uso de criadores, estudantes e técnicos. São Paulo: Melhoramentos, 1945. 289 p.

RENCTAS. Rede Nacional de Combate ao Tráfico de Animais Silvestres. $\mathbf{1}^{\circ}$ Relatório Nacional sobre o Tráfico de Fauna Silvestre. 2001. Disponível em: <http://www.renctas.org.br/files/REL_RENCTAS_pt_final.pdf>. Acesso em: 29 mar. 2008.

RITCHIE, B. W.; HARRISON, G. J.; HARRISON, L. R. Avian medicine: principles and application. Florida: Wingers, 1994. 1384 p.

ROSENTHAL, K.; HILLYER, E.; MATHIESSEN, D. Stifle luxation repair in a moluccan cockatoo and a barn owl. Journal of the Association of Avian Veterinarians, v. 8, n. 4, p. 173-178, 1994.

ROSSKOPF, W. J.; WOERPEL, R. W. Diseases of cage and aviary birds. 3. ed. Baltimore: Williams \& Wilkins, 1996. 1088 p.

RUPLEY, A. E. Cirurgia. In: . Manual de clínica aviária. São Paulo: Roca, 1999. p. 459-491.

SANTOS, G. C.; MATUELLA, G. A.; CORAIOLA, A. M.; SILVA, L. C.; LANGE, R. R.; SATIN, E. Doenças de aves selvagens diagnosticadas na Universidade Federal do Paraná (2003-2007). Pesquisa Veterinária Brasileira, v. 28, n. 11, p. 565-570, 2008.

SARMENTO, R. M.; SANCHES, A. W. D.; PACHALY, J. R. Tumor maligno de bainha nervosa em papagaio-verdadeiro (Amazona aestiva) - relato de caso. Clínica Veterinária, ano 13, n. 74, p. 46-50, 2008.

SATTERFIELD, W. C.; O'ROURKE, K. I. External skeletal fixation in avian orthopedics using a modified through-and- through Kirschner-Ehmer splint technique (The Boston Technique). Journal of the American Animal Hospital Association, v. 17, p. 635-637, 1981.

SCHMIDT, R. E.; LIGHTFOOT, T. L. Integument. In: HARRISON, G. J.; LIGHTFOOT, T. L. Clinical avian medicine. Florida: Spix, 2006. v. 1, p. 395-409. 
SCHMIDT, R. E; QUESENBERRY, K. Neoplasia. Neoplastic diseases. In: ALTMAN, R. B.; CLUBB, S. L.; DORRESTEIN, G. M.; QUESENBERRY, K. Avian medicine and surgery. Philadelphia: W. B. Saunders, 1997. p. 590-603.

SICK, H. Ornitologia brasileira. Rio de Janeiro: Nova Fronteira, 1997. 912 p.

SIMPSON, G. N. Trauma. In: BEYNON, P. H.; FORBES, N. A.; LAWTON, M. P. C. Manual of psittacine birds. Cheltenham: BSAVA, 1996. p. 186-189.

SINHORINI, J. A. Neoplasias em aves domésticas e silvestres mantidas em domicílio: avaliação anatomopatológica e imunoistoquímica. 2008. $131 \mathrm{f}$. Dissertação (Mestrado em Patologia Experimental e Comparada) - Faculdade de Medicina Veterinária e Zootecnia, Universidade de São Paulo, São Paulo, 2008.

SOUZA, M. J.; FIELDS, E. L.; DEGERNES, L. A. Thoracic and pelvic limb fracture and luxation management in raptors: a five-year retrospective study. Journal of Wildlife Rehabilitation, v. 27, n. 3-4, p. 5-13, 2004.

STERN, A. W.; LAMM, C. G. Malignant melanoma of the subcutaneous tissues in an umbrella cockatoo (Cacatua alba). Journal of Avian Medicine and Surgery, v. 23, n. 4, p. 303-306, 2009.

VOGEL, C.; GERLACH, H.; LÖFFLER, M. Columbiformes. In: RITCHIE, B. W.; HARRISON, G. J.; HARRISON, L. R. Avian medicine: principles and application. Florida: Wingers, 1994. p. 1200-1236.

WANDER, K. W.; SCHWARZ, P. D.; JAMES, S. P.; POWERS, B. E.; TAYLOR, B.; WIMSATT, J. H. Fracture healing after stabilization with intramedullary xenograft cortical bone pins: a study in pigeons. Veterinary Surgery, v. 29, p. 237-244, 2000.

WISE, J. K. Veterinary health care market for miscellaneous pets. Journal of American Veterinary Medical, v. 184, n. 6, p. 741-742, 1984.

WITHROW, S. J. General principles of fracture repair in raptors. Compendium on Continuing Education for Practicing Veterinarian, v. 4, n. 2, p. 116-121, 1982.

WORELL, A. B. Toucans and mynahs. In: ALTMAN, R. B.; CLUBB, S. L.; DORRESTEIN, G. M.; QUESENBERRY, K. Avian medicine and surgery. Philadelphia: W. B. Saunders, 1997. p. 910-917. 

APÊNDICES 



\section{APÊNDICE A - ORTOPEDIA}

Prontuário:

Espécie:

Proprietário/telefone:
RG

Idade:

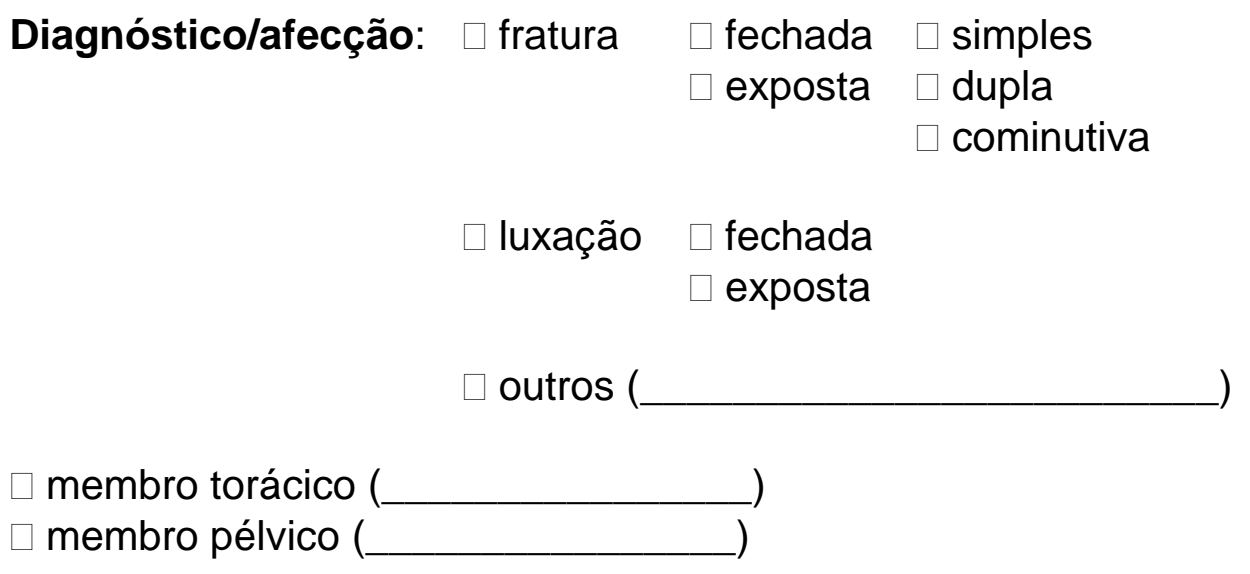

Técnica operatória: $\square$ fixação interna ( fixação externa outras(

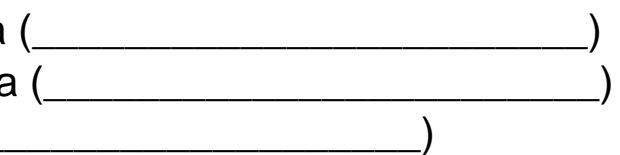

Avaliação radiográfica

Consolidação: $\quad \square$ não união

$\square$ reação periostal

$\square$ calo ósseo

$\square$ sem informação

Eixo ósseo: $\square$ ruim (grande desvio do eixo ósseo)

$$
\begin{aligned}
& \square \text { satisfatório (pequeno desvio do eixo ósseo) } \\
& \square \text { excelente (eixo ósseo mantido sem desvios) } \\
& \square \text { sem informação }
\end{aligned}
$$

\section{Retorno à função:}
$\square$ ausente $\square$ parcial
$\square$ total
óbito
sem informação

Observações: 


\section{APÊNDICE B - TECIDOS MOLES}

Prontuário:

Espécie:

RG

Proprietário/telefone:

Idade:

Exames pré-cirúrgicos: $\square \mathrm{RX} \quad \square \mathrm{US}$

Citologia $\square$ Cultura/Antibiograma

$\square$ Nenhum $\square$ outros (

Diagnóstico pré-cirúrgico:

Diagnóstico pós-cirúrgico imediato:

Técnica operatória:

Histopatológico:

Necrópsia:

Diagnóstico final/afecção:

\section{Pós-operatório imediato:}

$\square$ excelente (tratamento cirúrgico foi curativo)

$\square$ satisfatória (tratamento cirúrgico não foi curativo mas possibilitou diagnóstico)

$\square$ insatisfatória (o tratamento cirúrgico piorou a condição clínica do paciente)

$\square$ óbito (paciente obitou até 24 horas da realização do procedimento cirúrgico)

$\square$ sem informação

\section{Recidiva e seguimento:}

$\square$ não (o paciente não apresentou recidiva dentro do período do estudo)

$\square$ sim (o paciente apresentou recidiva dentro do período de estudo)

$\square$ óbito

$\square$ eutanásia

$\square$ sem informação

Observações: 


\section{APÊNDICE C}

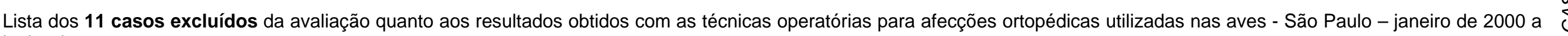
junho de 2008

\begin{tabular}{|c|c|c|c|c|c|c|c|c|c|c|c|c|c|c|c|c|}
\hline \multirow{3}{*}{$\mathrm{N}^{\circ}$ do caso } & \multirow{3}{*}{$\begin{array}{l}\text { Nome comum } \\
\text { (Nome científico) }\end{array}$} & \multirow{3}{*}{$\begin{array}{l}\text { Afecção ortopédica } \\
\text { (descrição completa) }\end{array}$} & \multirow{3}{*}{ Técnica operatória } & \multicolumn{8}{|c|}{ Avaliação radiográfica } & \multirow{2}{*}{\multicolumn{5}{|c|}{ Retorno à função }} \\
\hline & & & & \multicolumn{4}{|c|}{ Consolidação } & \multicolumn{4}{|c|}{ Eixo ósseo } & & & & & \\
\hline & & & & SI & 0 & 1 & 2 & SI & 0 & 1 & 2 & SI & 0 & 1 & 2 & 3 \\
\hline 2 & $\begin{array}{l}\text { Papagaio-verdadeiro } \\
\text { (Amazona aestiva) }\end{array}$ & Fratura fechada simples tibiotarso D & $\mathrm{FI}-\mathrm{PIM}+\mathrm{Ce}$ & & & $x$ & & & & & $x$ & $x$ & & & & \\
\hline 3 & $\begin{array}{l}\text { Tucano-toco } \\
\text { (Ramphastos toco) }\end{array}$ & Artrite e osteomielite bacteriana MPB & $\begin{array}{l}\text { Colheita material } \\
\text { (HP, CATB) }\end{array}$ & $x$ & & & & $x$ & & & & & & & & $x$ \\
\hline 5 & $\begin{array}{l}\text { Periquito-australiano } \\
\text { (Melopsittacus undulatus) }\end{array}$ & $\begin{array}{l}\text { Avulsão traumática de extremidade de } \\
\text { membro pélvico } D \S\end{array}$ & Amputação perna & $x$ & & & & $x$ & & & & & $x$ & & & \\
\hline 6 & $\begin{array}{l}\text { Cisne } \\
\text { (Cygnus sp.) }\end{array}$ & Fratura tibiotarso $\mathrm{D}$ & Não relatada & $x$ & & & & $x$ & & & & $x$ & & & & \\
\hline 7 & $\begin{array}{l}\text { Papagaio } \\
\text { (Amazona sp.) }\end{array}$ & Fratura fechada simples tibiotarso $\mathrm{E}$ & FI - PIM & $x$ & & & & $x$ & & & & $x$ & & & & \\
\hline 9 & $\begin{array}{l}\text { Papagaio } \\
\text { (Amazona sp.) }\end{array}$ & Fratura fechada simples tibiotarso D & FE - transfixador bipolar & & $x$ & & & & $x$ & & & $x$ & & & & \\
\hline 15 & $\begin{array}{l}\text { Calopsita } \\
\text { (Nymphicus hollandicus) }\end{array}$ & $\begin{array}{l}\text { Fratura fechada cominutiva tibiotarso E } \S \\
\text { (antiga) }\end{array}$ & Amputação perna & $x$ & & & & $x$ & & & & & $x$ & & & \\
\hline 16 & $\begin{array}{l}\text { Papagaio-de-peito-roxo } \\
(\text { Amazona vinacea *) }\end{array}$ & $\begin{array}{l}\text { Fratura exposta cominutiva rádio-ulna e } \\
\text { metacarpos } E \S \text { (antiga) }\end{array}$ & Amputação asa & $x$ & & & & $x$ & & & & & $x$ & & & \\
\hline 17 & $\begin{array}{l}\text { Papagaio } \\
\text { (Amazona sp.) }\end{array}$ & Fratura exposta úmero $\mathrm{E}$ & Amputação asa & $x$ & & & & $x$ & & & & & $x$ & & & \\
\hline 18 & $\begin{array}{l}\text { Periquito-verde } \\
\text { (Brotogeris sp.) }\end{array}$ & Fratura exposta tibiotarso $\mathrm{D}$ & Amputação perna & $x$ & & & & $x$ & & & & & & & & $x$ \\
\hline 27 & $\begin{array}{l}\text { Papagaio-verdadeiro } \\
\text { (Amazona aestiva) }\end{array}$ & Fratura fechada simples úmero $\mathrm{E}$ (antiga) & Amputação asa & $x$ & & & & $x$ & & & & & $x$ & & & \\
\hline
\end{tabular}

* espécies da Fauna Brasileira ameaçadas de extinção ; § associada à osteomielite; E - esquerdo; D - direito; SI - sem informação

Técnica operatória: FI - fixação interna, PIM - pino intramedular, Ce - cerclagem, HP - histopatológico, CATB - cultura e antibiograma, FE - fixação externa;

Consolidação: 0 - não união, 1 - reação periostal, 2 - calo ósseo;

Eixo ósseo: 0 - ruim (grande desvio do eixo ósseo), 1 - satisfatório (pequeno desvio do eixo ósseo), 2 - excelente (eixo ósseo mantido sem desvios)

Retorno à função: 0 - ausente, 1 - parcial, 2 - total, 3 - óbito 


\section{APÊNDICE D}

Lista dos 10 casos excluídos da avaliação quanto aos resultados obtidos com as técnicas operatórias para afecções de tecidos moles utilizadas nas aves São Paulo - janeiro de 2000 a junho de 2008

\begin{tabular}{|c|c|c|c|c|c|c|c|c|c|c|c|c|c|}
\hline \multirow{2}{*}{$\begin{array}{l}\mathrm{N}^{\circ} \text { do } \\
\text { caso }\end{array}$} & \multirow{2}{*}{$\begin{array}{l}\text { Nome comum } \\
\text { (Nome científico) }\end{array}$} & \multirow{2}{*}{$\begin{array}{l}\text { Afecção de tecidos moles } \\
\text { (diagnóstico final) }\end{array}$} & \multirow{2}{*}{ Técnica operatória } & \multicolumn{5}{|c|}{ Pós-operatório imediato } & \multicolumn{5}{|c|}{ Recidiva e seguimento } \\
\hline & & & & SI & $E$ & $\mathbf{S}$ & $\mathbf{I}$ & Obi* & Não & Sim & Obi & SI & Eut \\
\hline 4 & $\begin{array}{l}\text { Papagaio-verdadeiro } \\
\text { (Amazona aestiva) }\end{array}$ & Cáseo & Exérese & $x$ & & & & & & & & $x$ & \\
\hline 5 & $\begin{array}{l}\text { Arara-vermelha } \\
\text { (Ara macao) }\end{array}$ & Fístula de papo & Ingluvioplastia & $x$ & & & & & & & & $x$ & \\
\hline 14 & $\begin{array}{l}\text { Periquito-australiano } \\
\text { (Melopsittacus undulatus) }\end{array}$ & Hérnia abdominal & Herniorrafia abdominal & $x$ & & & & & & & & $x$ & \\
\hline 24 & $\begin{array}{l}\text { Curica, papagaio } \\
\text { (Amazona amazonica) }\end{array}$ & Lipoma abdominal e pericloacal & Exérese & $x$ & & & & & & & & $x$ & \\
\hline 49 & $\begin{array}{l}\text { Papagaio-verdadeiro } \\
\text { (Amazona aestiva) }\end{array}$ & $\begin{array}{l}\text { Neoformação cutânea sem } \\
\text { diagnóstico }\end{array}$ & Amputação asa & $x$ & & & & & & & & $x$ & \\
\hline 50 & $\begin{array}{l}\text { Periquito-verde } \\
\text { (Brotogeris sp.) }\end{array}$ & $\begin{array}{l}\text { Gangrena extremidade membro } \\
\text { pélvico }\end{array}$ & Amputação perna & $x$ & & & & & & & & $x$ & \\
\hline 54 & $\begin{array}{l}\text { Papagaio } \\
\text { (Amazona sp.) }\end{array}$ & Cisto infundibular ("cisto de pena") & Exérese & $x$ & & & & & & & & $x$ & \\
\hline 55 & $\begin{array}{l}\text { Papagaio-verdadeiro } \\
\text { (Amazona aestiva) }\end{array}$ & Otite & $\begin{array}{l}\text { Drenagem cáseo } \\
\text { Colheita material (CATB) }\end{array}$ & $x$ & & & & & & & & $x$ & \\
\hline 58 & $\begin{array}{l}\text { Papagaio-verdadeiro } \\
\text { (Amazona aestiva) }\end{array}$ & Linfoma & Exérese & $x$ & & & & & & & & $x$ & \\
\hline 61 & $\begin{array}{l}\text { Papagaio } \\
\text { (Amazona sp.) }\end{array}$ & Sinusite & $\begin{array}{l}\text { Drenagem cáseo } \\
\text { Colheita material (CATB) }\end{array}$ & $x$ & & & & & & & & $x$ & \\
\hline
\end{tabular}

SI - sem informação; Pós-operatório imediato: E - excelente (o tratamento cirúrgico foi curativo); S - satisfatório (o tratamento cirúrgico não foi curativo, porém possibilitou o diagnóstico), I - insatisfatório (o tratamento cirúrgico piorou a condição clínica do paciente); Obi* - óbito (o paciente obitou até 24 horas da realização do procedimento cirúrgico); Recidiva e seguimento: Não - o paciente não apresentou recidiva dentro do período do estudo; Sim - o paciente apresentou recidiva dentro do período de estudo; Obi - óbito; Eut - eutanásia; Técnica operatória: Cm - colheita de material (CATB - cultura e antibiograma) 